LBNL-49945

\title{
Estimating Carbon Dioxide Emissions Factors for the California Electric Power Sector
}

\author{
Chris Marnay, Diane Fisher, Scott Murtishaw, Amol Phadke \\ Lynn Price, Jayant Sathaye
}

August 2002

Energy Analysis Department

Environmental Energy Technologies Division

Lawrence Berkeley National Laboratory 



\section{EXECUTIVE SUMMARY}

The California Climate Action Registry ("Registry") was initially established in 2000 under Senate Bill 1771, and clarifying legislation (Senate Bill 527) was passed in September 2001. The Ernest Orlando Lawrence Berkeley National Laboratory (Berkeley $\mathrm{Lab}$ ) has been asked to provide technical assistance to the California Energy Commission (CEC) in establishing methods for calculating average and marginal electricity emissions factors, both historic and current, as well as statewide and for sub-regions. This study is exploratory in nature. It illustrates the use of three possible approaches and is not a rigorous estimation of actual emissions factors. While the Registry will ultimately cover emissions of all greenhouse gases (GHGs), presently it is focusing on carbon dioxide $\left(\mathrm{CO}_{2}\right)$. Thus, this study only considers $\mathrm{CO}_{2}$, which is by far the largest GHG emitted in the power sector. ${ }^{1}$

Associating $\mathrm{CO}_{2}$ emissions with electricity consumption encounters three major complications. First, electricity can be generated from a number of different primary energy sources, many of which are large sources of $\mathrm{CO}_{2}$ emissions (e.g., coal combustion) while others result in virtually no $\mathrm{CO}_{2}$ emissions (e.g., hydro). Second, the mix of generation resources used to meet loads may vary at different times of day or in different seasons. Third, electrical energy is transported over long distances by complex transmission and distribution systems, so the generation sources related to electricity usage can be difficult to trace and may occur far from the jurisdiction in which that energy is consumed. In other words, the emissions resulting from electricity consumption vary considerably depending on when and where it is used since this affects the generation sources providing the power.

There is no practical way to identify where or how all the electricity used by a certain customer was generated, but by reviewing public sources of data the total emission burden of a customer's electricity supplier can be found and an average emissions factor (AEF) calculated. These are useful for assigning a net emission burden to a facility. In addition, marginal emissions factors (MEFs) for estimating the effect of changing levels of usage can be calculated. MEFs are needed because emission rates at the margin are likely to diverge from the average. ${ }^{2}$

\footnotetext{
${ }^{1}$ Note that while the gas emission are referred to as $\mathrm{CO}_{2}$, quantities of emissions are reported in mass of equivalent carbon, where $1 \mathrm{~kg} \mathrm{CO}_{2}=0.27 \mathrm{~kg} \mathrm{C}$.

${ }^{2}$ Note that this is not a life cycle analysis. These emissions factors are intended to estimate only the emissions that take place within the boundaries of generating stations. Emissions incurred by the construction of electricity generation facilities and delivery infrastructure; by the extraction (including coalbed methane release), processing, and delivery of fuels to the power plant; or by utilities' support services (e.g. office buildings and maintenance operations) are not included. Even so, transmission and distribution losses should be included for purposes of the Registry. As such, it is recommended that Registry participants multiply the emissions factors reported here by 1.085 to correct for an average transmission and distribution loss of approximately $8 \%$.
} 


\section{Objective of the Project}

The overall objective of this task is to develop methods for estimating AEFs and MEFs that can provide an estimate of the combined net $\mathrm{CO}_{2}$ emissions from all generating facilities that provide electricity to California electricity customers. The method covers the historic period from 1990 to the present, with 1990 and 1999 used as test years. The factors derived take into account the location and time of consumption, direct contracts for power which may have certain atypical characteristics (e.g., "green" electricity from renewable resources), resource mixes of electricity providers, import and export of electricity from utility owned and other sources, and electricity from cogeneration.

It is assumed that the factors developed in this way will diverge considerably from simple statewide AEF estimates based on standardized inventory estimates that use conventions inconsistent with the goals of this work. A notable example concerns the treatment of imports, which despite providing a significant share of California's electricity supply picture, are excluded from inventory estimates of emissions, which are based on geographical boundaries of the state.

\section{Approach}

The California electricity sector has undergone significant changes since 1990, and this poses daunting challenges for establishing a consistent method for estimating emissions factors over this period. In addition, publicly distributed data series have changed significantly over this decade. California is a particularly difficult state for calculating emissions factors for several reasons: California's fuel mix is among the most diverse in the nation; a large share of California's electricity is supplied by independent power producers, much of which is from combined heat and power $(\mathrm{CHP})^{3}$; several California utilities own shares of generating facilities in other states; California imports much of its electricity in addition to the power from these California owned out-of-state resources; and direct retail access was in effect from 1998 to 2001.

Berkeley Lab developed three methods for calculating California electricity emissions factors. The first uses the Elfin model to simulate plant operations and estimate emissions for 1990. The second is an accounting method that draws primarily from public data sources (PDS). The third, used for the 1999 test year, is a spreadsheet that applies a simplified load duration curve (LDC). Table EX-1 compares these approaches and summarizes what is included in each approach.

\footnotetext{
${ }^{3}$ Total fuel consumption is reported by combined heat and power units on the Energy Information Administration survey forms, and several methodologies exist for determining how fuel consumption should be split between the heat and electric outputs. The approach used in this study assigned a fixed conversion efficiency of fuel input to useful thermal output and allocated the remaining fuel to electricity production.
} 
Table EX-1. Comparison of Three Methods for Estimating Emissions Factors

\begin{tabular}{|c|c|c|c|c|c|c|c|}
\hline Method & Year & $\begin{array}{c}\text { Average } \\
\text { Emission } \\
\text { Factors }\end{array}$ & $\begin{array}{c}\text { Marginal } \\
\text { Emissions } \\
\text { Factors }\end{array}$ & $\begin{array}{l}\text { Includes } \\
\text { Imports }\end{array}$ & $\begin{array}{l}\text { Includes } \\
\text { Exports }\end{array}$ & $\begin{array}{c}\text { Includes } \\
\text { CA-Owned } \\
\text { Out-Of-State } \\
\text { Generation }\end{array}$ & $\begin{array}{l}\text { Excludes } \\
\text { Specific } \\
\text { Purchases }\end{array}$ \\
\hline Elfin Model & 1990 & Yes & Yes & Yes & No & Yes & N/A \\
\hline $\begin{array}{l}\text { Public Data } \\
\text { Sources }\end{array}$ & 1999 & Yes & No & Yes $^{\mathrm{b}}$ & No & Yes & Yes \\
\hline $\begin{array}{l}\text { Load Duration } \\
\text { Curve }\end{array}$ & 1999 & Yes & Yes & Yes $^{\mathrm{b}}$ & No & Yes & $\mathrm{Yes} / \mathrm{No}^{\mathrm{c}}$ \\
\hline
\end{tabular}

a "Specific Purchases" refers to purchases of electricity by retailers for use in green power products. Generation and associated emissions for these products should be separated from the resources providing power for the general pool of grid electricity to avoid double counting.

${ }^{b}$ Imports are net imports. Thus, exports are not treated explicitly but are subtracted from import totals.

c The LDC approach could be modified to exclude specific purchases; however, this was not done for this report due to time limitations.

The Elfin model was used to simulate plant operations and estimate emissions for 1990 . This model was a widely used forecasting tool for utility power systems during the 1980s and early 1990s, roughly until publication of the last biennial CEC Electricity Report in 1996. Fortunately, old data sets that were compiled and publicly scrutinized during this period are still available in the public domain and can be used to replicate historic conditions. Data sets for six electricity utility service territories were provided by CEC and all were run for 1990. Elfin has its own built-in algorithms for estimating emissions from cogeneration and imports. This model provides a great deal of versatility for determining emissions factors. In addition to providing annual AEFs and MEFs for the state and each power control area $(\mathrm{PCA})^{4}$, it also estimates emissions factors on a monthly basis as well as for other subperiods, such as for on- and off-peak hours.

The second approach for deriving AEFs is an accounting method that draws primarily from U.S. Energy Information Administration (EIA) reporting forms, with some supplemental information from the CEC and the Federal Energy Regulatory Commission (FERC). This method was used to estimate emissions and derive AEFs for the 1999 test year. ${ }^{5}$ Historical data on power plant generation and fuel consumption were used to determine plant-specific emissions. These were then aggregated into emission totals for each PCA as well as the entire state.

Due to data limitations, several assumptions were made in order to calculate and assign emissions. One critical decision was that electricity was assumed to serve the load of the PCA where it was generated, an assumption that may not be very accurate with the deregulation of generation. ${ }^{6}$ The shares of generation from out-of-state plants partially

\footnotetext{
${ }^{4}$ A power control area is defined as a grid region for which one utility controls the dispatch of electricity. Some smaller utilities are embedded in the power control areas of larger utilities.

${ }^{5}$ The absence of data on non-utility generation and monthly utility loads precluded the use of the PDS approach to calculate emissions factors for 1990 .

${ }^{6}$ By late 1999, California's CAISO utilities had divested most of their thermal power plants to independent power producers; therefore, the relatively fixed relationship between customer load and the plant available
} 
owned by California utilities were also assumed to serve these utilities' loads before other imports would be purchased. Another important assumption concerns the estimation of imports, which were calculated as the difference between PCA generation (including the out of state assets) and total loads. Emissions associated with the imported electricity were calculated by multiplying the quantity of imported electricity by the AEF of the region from which the electricity was assumed to originate.

Other important methodological steps were taken to avoid overestimating emissions from certain plants. In order to avoid allocating total emissions from CHP units, emissions were assigned to grid electricity using a method of deducting fuel input for heat based on a standard conversion efficiency of fuel to useful thermal output. Additionally, specific purchases of electricity for green power products and the associated emissions were subtracted from the totals of the PCA in which the electricity was generated. ${ }^{7}$

The third methodology, used for the 1999 test year, is a spreadsheet that utilizes a load duration curve (LDC), as many simulation models do (such as Elfin), albeit in a simplified form. The approach uses publicly available data from the National Energy Modeling System (NEMS) input files. The LDC model provides estimates of annual and monthly AEFs and MEFs by an approximation of the complex plant operation algorithms of more sophisticated models. In the LDC method, plants were placed in order of probable dispatch as follows: 1) nuclear plants, 2) non-thermal imports 3) renewables such as wind, geothermal, and biomass, 4) co-generation facilities, and 5) hydro. All remaining resources (thermal, non-cogeneration facilities) were then taken in order of their capacity factors, highest to lowest. The LDC model makes the same assumption as the PDS approach regarding electricity serving the load of the PCA in which it was generated, although some results for the combined load of the California Independent System Operator (CAISO) are also presented. This is equivalent to treating the three CAISO utilities - Pacific Gas \& Electric (PG\&E), Southern California Electric (SCE), and San Diego Gas \& Electric (SDG\&E) as one PCA. Specific purchases have not been separated from the generation totals, but the model can be adapted to do so. Cogeneration did not require additional assumptions as the NEMS data files contain plant-specific heat rates for calculating fuel consumption for electricity generation from CHP plants.

\section{Results}

The annual results of the three approaches for the entire state and the four major California utilities are shown in Table EX-2. In terms of total electricity-related $\mathrm{CO}_{2}$ emissions, the three methods produced similar results. The Elfin model methodology shows total $\mathrm{CO}_{2}$ emissions of $26.1 \mathrm{MtC}$ in 1990 . Since the total state electricity load in 1999 was about 10 percent higher than in 1990, the larger total emissions of $29.5 \mathrm{MtC}$ and 29.0 MtC yielded by the LDC and PDS methods, respectively, are to be expected.

to serve it no longer holds. For lack of precise sales data, a traditional fixed relationship is assumed in this report.

${ }^{7}$ Specific purchases are purchases of electricity by marketers or distribution companies for use in green power products, as defined in California Senate Bill 1305. 
This ratio holds roughly true for the state and all PCAs but PG\&E. The higher PG\&E emissions reported by Elfin for 1990 are due largely to the fact that 1990 was a dry year, and gas plants were operated at greater capacity factors to compensate for lower hydro generation. For 1999, the PDS and LDC methods generated remarkably similar estimates for both the entire state and each PCA.

Table EX-2. Comparison of Annual Results from Three Electricity Emissions Factors Calculation Methodologies

\begin{tabular}{|c|c|c|c|c|c|c|c|c|c|}
\hline & \multicolumn{3}{|c|}{1990 -Elfin } & \multicolumn{3}{|c|}{1999 -LDC } & \multicolumn{3}{|c|}{1999 - PDS } \\
\hline & $\begin{array}{c}\text { Emissions } \\
\text { (MtC) }\end{array}$ & $\begin{array}{c}\text { AEF } \\
(\mathrm{kgC} / \mathrm{kWh})\end{array}$ & $\begin{array}{c}\text { MEF } \\
(\mathrm{kgC/kWh})\end{array}$ & $\begin{array}{c}\text { Emissions } \\
\text { (MtC) }\end{array}$ & $\begin{array}{c}\text { AEF } \\
(\mathrm{kgC} / \mathrm{kWh})\end{array}$ & $\begin{array}{c}\text { MEF } \\
(\mathrm{kgC} / \mathrm{kWh})\end{array}$ & $\begin{array}{c}\text { Emissions } \\
\text { (MtC) }\end{array}$ & $\begin{array}{c}\mathrm{AEF} \\
(\mathrm{kgC} / \mathrm{kWh})\end{array}$ & $\begin{array}{c}\text { MEF } \\
(\mathrm{kgC} / \mathrm{kWh})\end{array}$ \\
\hline SCE & 11.8 & 0.132 & 0.165 & 12.9 & 0.131 & 0.215 & 12.9 & 0.132 & $\mathrm{~N} / \mathrm{A}$ \\
\hline SDG\&E & 2.2 & 0.132 & 0.201 & 2.8 & 0.146 & 0.181 & 2.6 & 0.140 & N/A \\
\hline LADWP & 4.7 & 0.195 & 0.191 & 5.2 & 0.207 & 0.199 & 5.0 & 0.192 & N/A \\
\hline$P G \& E^{a}$ & 7.3 & 0.070 & 0.153 & 7.0 & 0.063 & 0.140 & 7.0 & 0.064 & N/A \\
\hline State $^{b}$ & 26.1 & 0.110 & & 29.5 & 0.105 & & 29.0 & 0.108 & \\
\hline
\end{tabular}

A principal finding here is that the level of $\mathrm{CO}_{2}$ associated with electricity usage varies considerably among the PCAs, although it comes as no surprise that these values are lower for PG\&E than for the southern California companies. PG\&E has a large share of carbon-free generation, such as hydro, nuclear, and predominantly hydro imports from the Pacific Northwest.

The LDC and Elfin models produced quite divergent MEFs for all the PCAs except LADWP. (MEFs were not calculated using the PDS methodology). The difference in Elfin's 1990 and the LDC-derived 1999 MEFs for SCE is especially striking. The high 1999 MEF using the LDC method occurs because a large share of the gas-fired generation in this PCA is from cogeneration, which is assumed not to respond to changes in the load. Thus, the load-following resources consist largely of imports from the Southwest. The difference between the 1990 and 1999 MEFs is also large for PG\&E, which has the greatest share of nuclear and hydro generation, two resources that are generally never curtailed to follow load. With the exception of LADWP, the MEFs are significantly higher than the corresponding AEFs. Since the MEFs of the PCAs other than LADWP range from 25 to over 200 percent greater than the corresponding AEFs, using AEFs to estimate the $\mathrm{CO}_{2}$ savings from reducing electricity usage would significantly underestimate actual savings.

Table EX-3 disaggregates California electricity generation, $\mathrm{CO}_{2}$ emissions and average emissions factors in 1999 by their source based on the PDS results. In-state electricity generation accounts for $63 \%$ of total California electric use, while $14 \%$ is out-of-state production owned by California utilities and the remaining $23 \%$ is imported. Coal produces a negligible share of California's in-state electricity, but is by far the predominant source of energy in the Southwest U.S. Thus, imports from Californiaowned out-of-state coal plants and other utilities in the Southwest significantly increase California's $\mathrm{CO}_{2}$ emissions and the statewide AEF. The emissions associated with the electricity from California-owned out-of-state plants alone raises the AEF by a third. 
Thus, a simple inventory approach that only counts emissions within California's borders underestimates the $\mathrm{CO}_{2}$ emissions from electricity used by California consumers.

Table EX-3. Total 1999 California Electricity Generation, Electricity-Related $\mathrm{CO}_{2}$ Emissions, and Average Emissions Disaggregated by Source ${ }^{a}$

\begin{tabular}{l|c|c|c|c|c|c}
\hline & In-State & $\begin{array}{c}\text { CA } \\
\text { owned } \\
\text { Out-of- } \\
\text { State }^{\text {b }}\end{array}$ & $\begin{array}{c}\text { Total In-State } \\
\text { + CA owned } \\
\text { Out-of-State }\end{array}$ & $\begin{array}{c}\text { SW } \\
\text { Imports }\end{array}$ & $\begin{array}{c}\text { NW } \\
\text { Imports }^{\text {d }}\end{array}$ & $\begin{array}{c}\text { Total } \\
\text { CA }\end{array}$ \\
\hline Generation (TWh) & 170.14 & 37.16 & 207.30 & 42.80 & 19.76 & 269.86 \\
$\mathrm{CO}_{2}$ Emissions $(\mathrm{MtC})$ & 11.92 & 7.36 & 19.28 & 8.32 & 1.41 & 29.01 \\
\hline $\mathrm{AEF}(\mathrm{kgC} / \mathrm{kWh})$ & 0.070 & 0.198 & 0.093 & 0.194 & 0.071 & 0.108 \\
\hline
\end{tabular}

Calculated from public data sources as described in Section III of this report. These figures exclude specific purchases.

${ }^{b}$ This refers to the generation shares of out-of-state plants owned by California utilities.

c This represents imports from the Southwest, a region that for purposes of this study includes Arizona, Nevada, New Mexico, Utah, and Colorado. The assumed share of imports from the Southwest is high due to the assumption that southern California utilities receive all imports from this region. Precise sales data would permit allocation of a greater share of imports to the Northwest, which would lower the state total emissions. If the shares were the same as those reported in CEC's California Electricity Generation 19832000 (roughly 53\% from the Northwest) (CEC 2001b), total emissions would be about 5\% lower.

${ }^{\mathrm{d}}$ The Northwest region is composed of Montana, Wyoming, Idaho, Washington, and Oregon.

The large share of seasonally varying hydro generation in California combined with typically hot late summer weather implies that AEFs may be higher when increased output from thermal generating sources must compensate for diminished hydro output. Conversely, as more thermal generation is used, the share of natural gas is likely to increase relative to coal, pushing down the AEF of thermal generation. Table EX-4 shows the AEFs calculated for May and October, months that usually have relatively high and low hydro generation. PG\&E, the most hydro-dependent PCA, has by far the largest variation between the two months. This occurs both because more gas-fired generation is used within the PCA and more electricity is imported from the Northwest. The fall in hydro generation also causes the AEF of the imported power to increase, as more coalfired electricity is used to replace the decline in hydropower. PG\&E, being the largest PCA, is a large enough share of the statewide total load that the seasonal change in its resource mix significantly affects the statewide AEF. The variation in the other PCAs is much less pronounced and due as much to random changes in plant operations as to differences in hydro output. These results suggest that accounting for seasonal changes in resource mix, particularly for entities located in the PG\&E service area, is important to accurately estimate emissions throughout the year. 
Table EX-4. 1999 Seasonal Changes in AEFs

\begin{tabular}{|c|c|c|c|c|c|c|c|}
\hline \multirow[t]{2}{*}{ Utility } & \multicolumn{3}{|c|}{ May } & \multicolumn{3}{|c|}{ October } & \multirow{2}{*}{$\begin{array}{c}\text { Percent } \\
\text { Difference } \\
\text { Oct/May, } \\
\text { PDS Total }\end{array}$} \\
\hline & $\begin{array}{c}\text { CA } \\
\text { Generation, } \\
\text { LDC }^{\mathrm{a}}\end{array}$ & $\begin{array}{c}\text { CA } \\
\begin{array}{c}\text { Generation, } \\
\text { PDS }^{\mathbf{a}}\end{array} \\
\end{array}$ & $\begin{array}{c}\text { Total w/ } \\
\text { Imports, } \\
\text { PDS }\end{array}$ & $\begin{array}{c}\text { CA } \\
\text { Generation, } \\
\text { LDC }^{\mathrm{a}} \\
\end{array}$ & $\begin{array}{c}\text { CA } \\
\begin{array}{c}\text { Generation, } \\
\text { PDS }^{\mathbf{a}}\end{array} \\
\end{array}$ & $\begin{array}{c}\text { Total w/ } \\
\text { Imports, } \\
\text { PDS }\end{array}$ & \\
\hline PG\&E & 0.046 & 0.043 & 0.046 & 0.079 & 0.079 & 0.083 & $79 \%$ \\
\hline SCE & 0.086 & 0.083 & 0.122 & 0.111 & 0.105 & 0.132 & $8 \%$ \\
\hline SDG\&E & 0.091 & 0.096 & 0.150 & 0.105 & 0.089 & 0.134 & $-11 \%$ \\
\hline LADWP & 0.205 & 0.194 & 0.192 & 0.208 & 0.184 & 0.184 & $-5 \%$ \\
\hline $\mathbf{C A}^{\mathbf{b}}$ & 0.082 & 0.074 & 0.098 & 0.113 & 0.103 & 0.117 & $19 \%$ \\
\hline
\end{tabular}

${ }^{a}$ Includes the shares of out-of-state plants owned by CA utilities.

${ }^{\mathrm{b}}$ Includes only the PCAs listed in the table.

\section{Summary of Findings}

1. A statewide AEF could drastically misestimate an entity's emissions due to the large differences in generating resources among the service areas.

2. Differentiating between marginal and average emissions is essential to accurately estimate the $\mathrm{CO}_{2}$ savings from reducing electricity use.

3. Seasonal differences in AEFs due to fluctuations in hydro generation should be accounted for at the statewide level, and particularly for the PG\&E area.

4. A more careful effort should be undertaken to interpret and apply the Elfin files in a consistent fashion to obtain more accurate results than are derived here. This will require better matching of historic data, better checking and standardizing of emission data, and better modeling of imports, exports, and trades.

5. The LDC approach proved promising and should be explored further. This approach can also be modified to consider variations in emissions by time-of-day, which could be of interest. 
I. INTRODUCTION

A. California Climate Action Registry 1

B. Objective of this Work 1

C. Methods and Major Issues 3

1. Calculating Electricity Emissions Factors for the Early 1990s

2. Method for Calculating Electricity Emissions Factors For the Mid-1990s Forward _ 3

3. Calculating Marginal vs. Average Emissions Factors __ 4

4. Accounting for Electricity Imports and Exports 5

5. Including Emissions from Electricity Produced by Non-Utility Generation Facilities __ 5

6. Accounting for Specific Purchases 6

D. Comparison of Methods

E. Outline of this Report

II. STANDARDS FOR CALCULATING ELECTRICITY EMISSION FACTORS

A. Existing Standards for Calculating Electricity Emissions Factors ___

B. International Approaches __ 9

1. Intergovernmental Panel on Climate Change (IPCC) Revised Guidelines for National Greenhouse Gas Inventories

2. The GHG Indicator: UNEP Guidelines for Calculating Greenhouse Gas Emissions from Businesses and Non-Commercial Organizations

3. The International Council for Local Environmental Initiatives (ICLEI) __ 10

C. National Approaches__ 11

1. Australia-Greenhouse Challenge_ 11

2. Canada - Voluntary Challenge Registry _ 12

3. United States - National Greenhouse Gas Inventory 12

4. United States - Voluntary Reporting of Greenhouse Gases Program - 1605(b) __ 13

5. United States - Climate Leaders Program 13

D. State Approaches 13

1. Emission Inventory Improvement Program _ 13

2. State Greenhouse Gas Inventories ___ 14

E. Non-Governmental Organization Approaches ___ 16

1. Greenhouse Gas Protocol Initiative 16

2. Environmental Resources Trust 16

F. Published California Electricity Emissions Factors __ 17

G. Standards Adopted in this Study __ 23

III. CALCULATING ELECTRICITY EMISSION FACTORS USING PUBLIC DATA SOURCES

$\begin{array}{llr}\text { A. Description of Data Sources } & \mathbf{2 6} \\ \text { B. Database Development } & \mathbf{2 6} \\ \text { 1. Utility Data } & 26 \\ 2 . \quad \text { Non-Utility Data } & 28\end{array}$ 
3. System Loads and Net Imports

4. Specific Purchases: "Green Power" and Power Content Disclosure (SB 1305)__ 29

C. Methodology

1. Fuel Conversion Factors: Coal 29

2. Fuel Conversion Factors: Other Fuels _ 30

3. Non-Utility Self-Generation and Cogeneration __ 31

4. Accounting for Out-of-State Plants Partially Owned by California Utilities ___ 32

5. Estimating Imports and Associated $\mathrm{CO}_{2}$ Emissions ___ 33

6. Accounting for Specific Purchases __ 34

D. Prospects for Future Data

E. Results_ 35

IV. CALCULATING ELECTRICITY EMISSION FACTORS FOR THE EARLY 1990S: ELFIN SIMULATION

A. Strengths and Limitations of the Elfin Approach __ 39

B. Description of Elfin Data Sets __ 40

C. Modeling Assumptions

1. Eliminate plants installed between 1990 and 1993

2. Input actual 1990 electricity sales by utilities $\quad 42$

3. Input actual hydroelectricity production for $1990 \_43$

4. Correct Nuclear Generation for 1990 Conditions _ 44

D. Method for Determining Average and Marginal Electricity $\mathrm{CO}_{2}$ Emissions Factors

E. Results $\quad 47$

F. Prospects for the Elfin Model ___ 49

V. METHODOLOGY FOR CALCULATING ELECTRICITY EMISSIONS FACTORS FOR THE MID-1990S FORWARD: SIMPLE LOAD DURATION

CURVE APPROACH

A. Description of Method _ 51

B. Data Sources _ 54

C. Implementation

D. Results__ 58

E. Prospects for LDC Method ___ 63

VI. CONCLUSION

A. Comparison of Results

B. Lessons Learned from Developing Each Method _ 66

1. Public Data Sources 66

2. Elfin 67

3. Load Duration Curve _ 67

VII. ACKNOWLEDGMENTS AND FUNDING STATEMENT__ 69

VIII.GLOSSARY 70

IX. BIBLIOGRAPHY 


\section{List of Figures}

Figure 1. Electricity Generation Fuel Shares by PCA, without Imports 37

Figure 2. Total Annual Hydro Generation in CA, 1983-2000 and Long Run Average___ 44

Figure 3. Corrected 1990 Monthly Hydro Generation for PG\&E

Figure 4. 1990 Monthly Pattern of Nuclear Generation - Diablo Canyon Units 1 \& 2 44

Figure 5. Example Load Decrements and the Corresponding MEF Estimate for PG\&E 45

Figure 6. Shares of Electricity Generation and Emissions from Four Generation Types 46

Figure 7. Actual 1999 CAISO Load 49

Figure 9. Merit Order Dispatch

Figure 10. Estimating the Marginal Emissions Factor 


\section{List of Tables}

Table 1. Comparison of Characteristics of Electricity Emissions Factor Calculation Methods 7

Table 2. Characteristics of Greenhouse Gas Inventories, Registries, and Protocols 18

Table 3. Comparison of Published Average Annual Electricity $\mathrm{CO}_{2}$ Emissions Factors for California 21

Table 4. Federal and California State Data Sources Used to Calculate Average Emissions Factors 27 Table 5: 1999 Coal Heat Content Factors for States in the Western Systems Coordinating Council, $\overline{M J / k g}$

Table 6. $1999 \mathrm{CO}_{2}$ Emissions Factors of Coal Consumed by Electric Utilities, $\mathrm{kgC/GJ}$

Table 7. 1999 Heat and Carbon Conversion Factors and Sources__ 31

Table 8. CA utility ownership shares of out-of-state plants____ 33

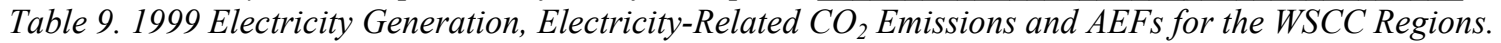

Table 10. 1999 California Electricity Generation, CO2 Emissions, and AEFs by Source 34

Table 11. 1999 Electricity Generation, CO2 Emissions and AEFs by Power Control Area 35

Table 12. 1999 PCA and Statewide Emissions Factors In-State And With Imports, May \& October 36

Table 13. Elfin Default Simulation and Base Years for California Utilities

Table 14. Variability of AEFs for 1993 data and different run years. 37

42

Table 15. 1990 Total Electricity Generation, Emissions, AEF, and $\overline{M E F \text { by UDC }} 47$

Table 16. Emissions from Out of State Power Plants, Imports, and Exports __ 48

Table 17. California Electricity Emissions Factors under Two Approaches

Table 18. Fuel Cost and Carbon Content Values by NEMS Fuel Code _ 56

Table 19. Calculation of Net Imports by Region__ 57

Table 20. Fuel Mixes of California Utilities (including utility-owned out-of-state plants)__ 59

Table 21. Generation by Fuel Type as Reported by the California Energy Commission, for $1999 \_59$

Table 22. Average Carbon Emissions Factors for California Utilities, $\mathrm{kg} \mathrm{C/kWh}$

Table 23. Monthly Average Carbon Emissions Factors for $1999 \mathrm{in} \mathrm{kgC/kWh}$, Excluding Imports_ 60

Table 24. Marginal Carbon Emissions Factors for 1999, in $\mathrm{kgC/kWh} \_61$

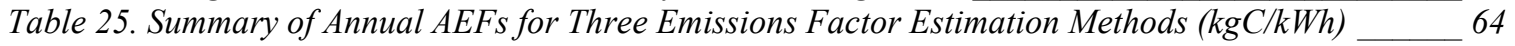

Table 26. Comparison of Annual MEFs from Two Electricity Emissions Factor Calculation Methods ${ }^{a}$ $(\mathrm{kgC/} / \mathrm{Wh})$ 64

Table 27. 1999 Seasonal Changes in Average Emissions Factors (kgC/kWh) 65 


\section{INTRODUCTION}

\section{A. CALIFornia Climate ACtion Registry}

The California Climate Action Registry ("Registry") was initially established in 2000 under Senate Bill 1771, and clarifying legislation (Senate Bill 527) was passed in September 2001 (CA Climate Action Registry, 2002). Initially, the Registry's voluntary participants need only report carbon dioxide $\left(\mathrm{CO}_{2}\right)$ emissions; other Kyoto greenhouse gases (GHGs) will be added later. Participants report $\mathrm{CO}_{2}$ emissions back to 1990, if possible, in order to establish their historical baseline. Thereafter and into the future, Registry participants will calculate both their direct and indirect emissions of GHGs and report them to the registry annually. Direct emissions include emissions from on-site combustion and from vehicle fleets. GHG release related to electricity use is considered indirect because its associated emissions virtually all take place at the location of power generation or upstream of it in the fuel supply chain and not at the location of electricity consumption.

SB 527 requires development of guidance to the Registry on "[e]stablishing entities' electricity usage and assigning $\mathrm{CO}_{2}$ emissions with that usage." The Ernest Orlando Lawrence Berkeley National Laboratory ("Berkeley Lab") has been asked to provide technical assistance to the California Energy Commission (CEC) in establishing methods for calculation of average and marginal electricity-related emissions factors, both historic and current, as well as statewide and for sub-regions. This study is intended as an exploration of alternative methods. Given the scope of the report, the results derived are not meant to serve as rigorous calculations of actual emissions factors. Based on the findings presented here and other considerations, the CEC will ultimately make recommendations to the Registry as to which approach or combination of approaches should be used.

\section{B. OBJECTIVE OF THIS WORK}

The purpose of this project is to explore various approaches to estimating average emissions factors (AEFs) and marginal emissions factors (MEFs) that can translate the electricity use of California consumers into a net $\mathrm{CO}_{2}$ emissions responsibility. ${ }^{8}$ In other words, these factors should, given a typical customer electricity bill and no other information, produce a reasonable estimate of the net mass of carbon emissions that the

\footnotetext{
${ }^{8}$ Note that this is not a life cycle analysis. These emissions factors are intended to estimate only the emissions that take place within the boundaries of generating stations. Emissions incurred by the construction of electricity generation facilities and delivery infrastructure; by the extraction (including coalbed methane release), processing, and delivery of fuels to the power plant; or by utilities' support services (e.g. office buildings and maintenance operations) are not included. Even so, transmission and distribution losses should be included for purposes of the Registry. As such, it is recommended that Registry participants multiply the emissions factors reported here by 1.085 to correct for an average transmission and distribution loss of approximately $8 \%$ (see also A.D. Little, 2002).
} 
customer is responsible for over the period covered by the bill. The factors should also enable estimation of the net changes in emissions as customer usage patterns change. ${ }^{9}$

The methods for calculating electricity emissions factors cover the historic period from 1990 to the present, with 1990 and 1999 used as test years. ${ }^{10}$ One goal of the work was to develop a method capable of routinely calculating electricity emissions factors with future years' data, as it becomes available, such that reliable and consistent electricity emissions factors can be created and maintained.

Associating $\mathrm{CO}_{2}$ emissions with electricity consumption encounters three major complications. First, electricity can be generated from a number of different primary energy sources, many of which are major sources of $\mathrm{CO}_{2}$ emissions (e.g. coal combustion) while others result in virtually no $\mathrm{CO}_{2}$ emissions (e.g. hydro). Second, since electricity cannot be readily stored and must be generated at the instant of consumption, the mix of generation resources used to meet loads may vary at different times of day or in different seasons since increasing demand may be met by resources that differ from the average. Third, electrical energy is transported over huge distances by a highly complex transmission and distribution system so the emissions related to electricity usage can occur far from the jurisdiction in which that energy is consumed. In other words, the carbon emissions resulting from electricity consumption vary considerably depending on how it is produced and when and where it is used.

California is a particularly challenging state for calculating emissions factors for several reasons: California's fuel mix is among the most diverse in the nation; a large share of California's electricity is supplied by independent power producers, much of which is from combined heat and power $(\mathrm{CHP})^{11}$; several California utilities own shares of generating facilities in other states; California imports much of its electricity in addition to the power from these California owned out-of-state resources; and direct retail access was in effect from 1998 to 2001.

Berkeley Lab developed three methods for calculating California electricity emissions factors. The first uses the Elfin model to simulate plant operations and estimate emissions for 1990. The second is an accounting method that draws primarily from public data sources (PDS). The third, used for the 1999 test year, is a spreadsheet that applies a simplified load duration curve (LDC).

\footnotetext{
${ }^{9}$ While the Registry will ultimately include all six major GHGs, carbon dioxide $\left(\mathrm{CO}_{2}\right)$ is by far the most important GHG associated with power generation, and the Registry legislation requires all emissions to be expressed carbon equivalents. This analysis examines $\mathrm{CO}_{2}$ emissions, reported in units of carbon (C).

${ }^{10} 1999$ was chosen due to the availability of monthly non-utility generation data beginning in that year.

${ }^{11}$ Total fuel consumption is reported by combined heat and power units on the U.S. Energy Information Administration survey forms, and several methodologies exist for determining how fuel consumption should be split between the heat and electric outputs. The approach used in this study assigned a fixed conversion efficiency of fuel input to useful thermal output and allocated the remaining fuel to electricity production.
} 


\section{METHODS AND MAJOR ISSUES}

\section{Calculating Electricity Emissions Factors for the Early 1990s}

The first method for calculating statewide average as well as service area AEFs and MEFs for the early 1990s is based on running the Elfin (from Electrical-Financial) model using Biennial Resource Plan Update (BRPU) datasets. These datasets roughly cover the 1992-1996 period; Berkeley Lab developed a method to replicate 1990. While simulation models such as Elfin are most frequently used for forecasting, they may also be used to simulate historic periods of operation. The importance of obtaining robust estimates of emissions for the base year of 1990 led Berkeley Lab to focus on Elfin modeling for this period.

The CEC provided Berkeley Lab with historic data sets from the Electricity Report 96 (ER96) proceeding and some output from the ER92 proceeding. Additional information is available from the ERs themselves and their supporting Electricity Supply Planning Assumption Report (ESPAR) materials, which are appendices to the ERs (CEC, 1990; CEC, 1993; CEC, 1995). These data sets were used to produce baseline estimates of 1990 emissions and can also serve as a basis for comparison with other data sources. The data sets embedded in Elfin BRPU input files are particularly valuable for several reasons: first, they were collected during the early 1990s, when relatively few other public sources of carbon emissions data were available; second, they were publicly reviewed and contested; third, they are in a form that allows translation into carbon emissions and that potentially allows updating; and finally, they were constructed with the participation of multiple parties, including the utilities that then owned most generating stations in the state. Berkeley Lab tested the Elfin method for 1990 and verified the results with state and service-area averages based on primary data from the U.S. Energy Information Administration (EIA) and the Federal Energy Regulatory Commission (FERC).

\section{Method for Calculating Electricity Emissions Factors For the Mid-1990s Forward}

The second approach for deriving AEFs is an accounting method that draws primarily from EIA reporting forms, with some supplemental information from the CEC and FERC. This method was used to estimate emissions and derive AEFs for the 1999 test year. ${ }^{12}$ Historical data on power plant generation and fuel consumption were used to determine plant-specific emissions. These were then aggregated into emission totals for each power control area (PCA) ${ }^{13}$ as well as the entire state.

Emissions from CHP units were assigned using a method of deducting fuel input for heat based on a standard conversion efficiency of fuel to useful thermal output. Electricity was

\footnotetext{
${ }^{12}$ The absence of data on non-utility generation and monthly utility loads precluded the use of the PDS approach to calculate emissions factors for 1990 .

${ }^{13}$ A power control area is defined as a grid region for which one utility controls the dispatch of electricity. Some smaller utilities are embedded in the power control areas of larger utilities.
} 
assumed to serve the load of the PCA where it was generated, and data on PCA generation and loads were used to estimate electricity imports. ${ }^{14}$ The shares of generation from out-of-state plants partially owned by California utilities were also assumed to serve these utilities' loads before other imports would be purchased.

Out-of-state emissions associated with imported electricity were calculated by multiplying the quantity of imported electricity by the AEF of the region from which the electricity was assumed to originate. Specific purchases of electricity for green power products and the associated emissions were subtracted from the totals of the PCA in which the electricity was generated (see footnote 7 ).

The third methodology, used for the 1999 test year, is a spreadsheet that utilizes a load duration curve (LDC), as many simulation models do (such as Elfin), albeit in a simplified form. The approach uses publicly available data from the National Energy Modeling System (NEMS) input files. The LDC model provides estimates of annual and monthly AEFs and MEFs by an approximation of the complex plant operation algorithms of more sophisticated models. In the LDC method, plants were placed in order of probable dispatch as follows: 1) nuclear plants, 2) non-thermal imports 3) renewables such as wind, geothermal, and biomass, 4) co-generation facilities, and 5) hydro. All remaining resources (thermal, non-cogeneration facilities) were then taken in order of their capacity factors, highest to lowest. The LDC model makes the same assumption as the PDS approach regarding electricity serving the load of the PCA in which it was generated, although some results for the combined load of the California Independent System Operator (CAISO) are also presented. This is equivalent to treating the three CAISO utilities - Pacific Gas \& Electric (PG\&E), Southern California Electric (SCE), and San Diego Gas \& Electric (SDG\&E) as one PCA. Specific purchases have not been separated from the generation totals, but the model can be adapted to do so. Cogeneration did not require additional assumptions as the NEMS data files contain plant-specific heat rates for calculating fuel consumption for electricity generation from CHP plants.

\section{Calculating Marginal vs. Average Emissions Factors}

Most power generating systems use multiple fuels to produce electricity: coal, nuclear, natural gas, and hydro and other renewables. California differs substantially from the U.S. norm in that it has much larger shares of natural gas generation, "eligible" renewables (small hydro, geothermal, solar, biomass, wind, etc.), ${ }^{15}$ and imported

\footnotetext{
${ }^{14}$ By late 1999, California's CAISO utilities had divested most of their thermal power plants to independent power producers; therefore, the relatively fixed relationship between customer load and the plant available to serve it no longer holds. For lack of precise sales data, a traditional fixed relationship is assumed in this report.

${ }^{15}$ The actual in-state fuel mix for 1999 was $43 \%$ natural gas, 22\% large (>30 MW) hydro, $2 \%$ coal, 20\% nuclear, $12 \%$ renewables, and 1\% fuel oil (calculated using EIA form 759 and $860 \mathrm{~B}$ forms). This does not account for imports or California-owned out-of-state electricity generation. The 1999 CEC calculation of Net System Power in California, including imports, was made up of $19.8 \%$ coal, $20.1 \%$ large hydro, 31.0\% natural gas, $16.2 \%$ nuclear, $12.2 \%$ eligible renewables, and $0.6 \%$ other (CEC, 2001a).
} 
electricity. ${ }^{16}$ Unfortunately, the emissions factors of these fuels vary enormously. Since economic efficiency requires that the least expensive combination of resources be used to meet the load at a given moment, the marginal generator that varies its output to meet changing load must be the most expensive one on line. Here most expensive means specifically the one with highest variable operating cost, i.e. the one that can deliver the highest reduction in total cost by reducing its output. Depending on what type of plant serves as the marginal generator, the marginal emissions factor could vary from zero to the high values associated with coal-fired generation. ${ }^{17}$ Therefore, using an AEF, whether annual or monthly, may provide a poorer estimate of the impact of a customer's electricity usage reduction on actual emissions than a MEF.

In the case of California, natural gas is often the fuel offset by reduced demand. Conventional wisdom is that as a first approximation, single cycle natural gas generation emissions provide a reasonable estimate of the marginal emission rate. Berkeley Lab adapted a load duration curve model to the California power mix in part to test this belief.

\section{Accounting for Electricity Imports and Exports}

Since California relies on such a large share of imported electricity to meet its energy needs, accounting for the emissions from this electricity is crucial to obtaining accurate electricity emissions factors. While the Elfin datasets contain information that permits a rudimentary simulation of purchases of imported electricity, the LDC and PDS methods draw on information from primary sources. At the statewide level, net annual imports from the Southwest and Northwest regions are available from the CEC, while monthly and annual imports for each PCA were calculated as the difference between load and PCA generation.

\section{Including Emissions from Electricity Produced by Non-Utility Generation Facilities}

EIA data for all non-utility power producers is confidential prior to 1998, which hinders PDS calculations for previous years. An additional concern is that, in California, combined heat and power plants (CHP or cogenerators) provide a large share of the state's electricity. ${ }^{18}$ This creates a substantial practical problem because it is not clear what share of the GHG emissions produced by the combustion of fossil fuels at these plants should be allocated to the electricity-generating sector. This problem can be sidestepped in estimation of MEFs because output from CHP can reasonably be assumed

\footnotetext{
${ }^{16}$ In 1999 , imported electricity was $18 \%$ according to CEC data (CEC, 2001b), but this counts power from out-of-state plants owned by California utilities as in-state generation (Pan, 2001). This differs from our calculations of import shares (Table EX-3) because CEC shows a higher total of in-state generation.

${ }^{17}$ For example, the Mohave coal station emits approximately $0.266 \mathrm{kgC} / \mathrm{kWh}$ vs. zero emissions from noncarbon fuels. This emissions factor was calculated using data from EIA Form 759 with coal heat factors from the 1999 State Energy Data Report (U.S. DOE/EIA, 2001c) and coal carbon/heat conversion factors from U.S. DOE/EIA, 2000.

${ }^{18}$ In 1999, according to calculations from the EIA Forms 759 and 860B, about 23 percent of the electricity generated for the California grid by in-state sources was from cogenerators.
} 
to never be curtailed. This assumption is based on the notion that CHP operations are primarily determined by the non-electricity heat requirements, making the electricity output insensitive to changing conditions in the short run.

\section{Accounting for Specific Purchases}

With the advent of retail competition in 1998, energy service providers (ESPs) began offering green power products whose generation resources differed from the average California mix. The specific purchases of electricity for these products need to be accounted for and separated from the general power pool to avoid double counting. ${ }^{19}$ Under the provisions of SB 1305, which regulates green power sales in California, electricity retailers must report detailed information on their purchases to the CEC in order to distinguish their green power products from the general California power mix. The information from the specific purchase reports can be used to exclude the associated generation and emissions, but it may not capture all power purchased under direct contracts (e.g. contracts between large industrial facilities and energy service providers).

\section{COMPARISON OF METHODS}

Table 1 provides a comparison of the various electricity generation facilities included in the three methods presented in this report as well as those included in the CEC GHG emissions inventory for California (CEC, 1998). As shown, Elfin was used to generate electricity emissions factors for the test year 1990 while the LDC model and PDS database were used to generate electricity emissions factors for the test year 1999.

The two models and the PDS database all provide average annual and monthly electricity AEFs at the state level and by utility service district. The two models also provide annual and monthly MEFs at the state level and by utility service district. All three include imported electricity, utility-owned in-state generation, utility-owned out-of-state generation, and non-utility generation while excluding exports from the state. ${ }^{20}$ Specific purchases can be excluded from the load duration curve and database methods, but have only been actually accounted for in the PDS method since the 1999 specific purchase data were obtained and analyzed late in the study.

In contrast, the inventory of California GHG emissions (which covers 1990-1994 and was not intended to provide a calculation of electricity emissions factors) provides data that allows calculation of a state-wide AEF, but that factor only includes in-state emissions while excluding emissions from imports and utility-owned out-of-state generation.

\footnotetext{
${ }^{19}$ According to CEC data from the Power Source Disclosure Program, the amount of power claimed under specific purchases in 1999 was below three percent of all power sold in California that year (CEC, 2001d; CEC, 2001b).

${ }^{20}$ The LDC and PDS methods calculate net imports by taking the annual or monthly loads and subtracting the intra-PCA generation, assuming the difference must equal net imports. Exports are not treated explicitly.
} 
Table 1. Comparison of Characteristics of Electricity Emissions Factor Calculation Methods

\begin{tabular}{|c|c|c|c|c|}
\hline Method & Elfin Model & $\begin{array}{l}\text { Load Duration } \\
\text { Curve }\end{array}$ & $\begin{array}{l}\text { Public Data } \\
\text { Source }\end{array}$ & $\begin{array}{c}\text { CA } \\
\text { Inventory }\end{array}$ \\
\hline Year & 1990 & 1999 & 1999 & 1990-1994 \\
\hline Average Emission Factor & Yes & Yes & Yes & Yes \\
\hline Marginal Emissions Factor & Yes & Yes & No & No \\
\hline Includes Imports & Yes & Yes & Yes $^{\mathrm{b}}$ & No \\
\hline Includes Exports & No & No & No & Yes \\
\hline $\begin{array}{l}\text { Includes Utility-Owned In-State } \\
\text { Generation }\end{array}$ & Yes & Yes & Yes & Yes \\
\hline $\begin{array}{l}\text { Includes Utility-Owned Out-Of- } \\
\text { State Generation }\end{array}$ & Yes & Yes & Yes & No \\
\hline Includes Non-Utility Generation & Yes & Yes & Yes & Yes \\
\hline Includes Specific Purchases & N/A & $\mathrm{Yes} / \mathrm{No}^{\mathrm{a}}$ & Yes & No \\
\hline
\end{tabular}

\section{E. OUTLINE OF THIS REPORT}

Section II of this report provides an overview of other efforts to calculate electricity emissions factors and discusses some of the standards they have adopted for estimation of indirect $\mathrm{CO}_{2}$ emissions by electricity customers.

Section III covers the PDS estimation of AEFs from plant-level generation and fuel consumption data. These factors are estimated by relying on public data sources, including data released by major public agencies such as the Energy Information Administration of the U.S. Department of Energy, the U.S. Environmental Protection Agency, the Federal Energy Regulatory Commission, and the CEC. In cases where the necessary data were not available, assumptions are made and described.

Section IV covers the use of the Elfin model to estimate 1990 electricity emissions factors. The Elfin electricity utility production cost simulation model was used in formal CEC proceedings during the early to mid-1990's but was subsequently abandoned. The section describes the process by which the Elfin input files used in early 1990s Biennial Resource Planning Update (BRPU) process are recovered, reinstalled, and modified to match 1990 conditions. Key to this process is the development of cases for each utility distribution company (UDC). ${ }^{21}$

${ }^{21}$ Use of the term Utility Distribution Company (UDC) came about during the restructuring of California's electricity market when the prior vertically integrated companies divested much of their generating assets and relinquished control of high voltage transmission lines to CAISO. Since their remaining business was dominated by the medium and low voltage distribution system, they became known as UDCs. However, since divestiture remains incomplete and retail electricity competition was abandoned, the current 
Section V describes the LDC model, which is based on the use of a simple load duration curve using public domain data to estimate emissions factors. This method, like Elfin, provides both MEFs and AEFs.

Section VI provides a common comparison of the results obtained by the three methods covered in sections III-V. The three methods are different enough that the results are not always directly comparable, as the different years covered alone clearly attests, but in this section, comparisons are made and conclusions are drawn.

Finally, the Conclusion presents a comparison of the major findings from each of the three methods and reviews some of the lessons learned in developing them.

electricity companies are hybrids between traditional vertically integrated, territorially defined utilities as existed in 1990, and the UDCs that the restructuring plan envisaged. Because the regulatory and/or management structure of the organizations is not important in this work, UDC is applied loosely to all electricity utilities, including the municipally owned ones, primarily SMUD and LADWP. 


\section{STANDARDS FOR CALCULATING ELECTRICITY EMISSION FACTORS}

\section{A. EXISTING STANDARDS FOR CALCULATING ELECTRICITY EMISSIONS FACTORS}

There are a number of approaches to calculating $\mathrm{CO}_{2}$ emissions from electricity consumption. This section reviews how such calculations are made in international, national, state, and non-governmental efforts to document GHG emissions. These efforts quantify emissions at either the project level or at the entity-wide level, where entities are defined as countries, states, municipalities, or businesses. In many of the efforts reviewed, emissions were calculated using default emissions factors rather than calculating entity-specific values. These default values are usually national, state, or provincial-level AEFs provided by government agencies. In some cases, businesses are given the option of developing their own company-specific electricity emissions factors based on local utility electricity $\mathrm{CO}_{2}$ emissions factors and accounting for on-site cogeneration of electricity.

Table 2 (page 18) provides a summary of some characteristics of these GHG inventories, protocols, and registries. First, the scope of the effort is defined in terms of whether direct emissions from fuels, indirect emissions from electricity production and other sources, and carbon sinks are included. Next, whether the effort is focused at the project or the entity-wide level (e.g., country, state, province, municipality, business) is noted. The method for calculating the electricity EF is briefly described and the level of participation is indicated if known. Note that none of the major protocols reviewed here provide MEFs or a methodology to calculate them.

\section{B. INTERNATIONAL APPROACHES}

\section{Intergovernmental Panel on Climate Change (IPCC) Revised Guidelines for National Greenhouse Gas Inventories}

The IPCC guidelines provide a method for countries to estimate GHG emissions from each major sector of the economy, such as energy, industrial processes, agriculture, land use change and forestry, and waste, as well as GHG removal by sinks. These guidelines form the basis of national GHG accounting under the United Nations Framework Convention on Climate Change and as such are a widely accepted international standard (IPCC 1996). The IPCC guidelines are used by countries to calculate GHG inventories for their National Communications. To date, 35 Annex I and 51 non-Annex I countries have submitted National Communication reports (UN, 2001).

Since the IPCC guidelines are designed to account for emissions at the national level, emissions calculations are made for primary energy sources only. GHG emissions from utilities are thus assigned to the energy transformation sector and no method for calculating emissions factors for purchased electricity is given. 


\section{The GHG Indicator: UNEP Guidelines for Calculating Greenhouse Gas Emissions from Businesses and Non-Commercial Organizations}

The United Nations Environment Programme (UNEP) GHG Indicator was initiated by a report by the Centre for Environmental Technology at London's Imperial College published in 1997 that discussed establishing a standardized method for measuring a company's GHG emissions. Some of the partner organizations include the World Resources Institute, the World Business Council for Sustainable Development, the International Energy Agency, the European Bank for Reconstruction and Development, and Blue Circle Industries. The GHG Indicator has been developed to be most useful for companies and as such can be applied to individual sites, specific lines of the business, or to the entire parent company. The GHG Indicator provides GHG emissions factors for fuel consumption, electricity use, transport, and process-related emissions and provides a process for calculating an annual "Total GHG" indicator for a company. Carbon offset and sequestration options are not included.

$\mathrm{CO}_{2}$ emissions from electricity for most countries for 1990 and 1996 are calculated using data from the International Energy Agency (IEA) and the resulting emissions factors are similar to those reported in most Annex 1 country National Communications. Even so, the UNEP guidelines recommend using national factors if known. The method for calculating national average factors from IEA data is explained as follows:

"The factors have been calculated by taking $\mathrm{CO}_{2}$ emissions from public electricity and heat production which incorporate emissions from public electricity generation, public combined heat and power generation and public heat plants. Total emissions are then divided by total electricity production, including electricity from nuclear power and renewables, which are assumed to have zero $\mathrm{CO}_{2}$ emissions, to arrive at an emissions factor of tonnes of $\mathrm{CO}_{2}$ per $\mathrm{kWh}$ of electricity produced."

Emissions factors for electricity produced using combined heat and power (CHP) systems are calculated separately and are based on whether the entity imports or exports electricity from the CHP-based system. The Protocol provides a worksheet for the entity to use to calculate these emissions, accounting for the fuels used in the CHP unit and the amount of electricity it produces, in order to derive a value for imported or exported $\mathrm{CO}_{2}$ to add or subtract to the entity total (Thomas et al., 2000).

\section{The International Council for Local Environmental Initiatives (ICLEI)}

The ICLEI analytical framework for urban greenhouse gas emissions and emissions reductions is designed as a tool for local government energy and emissions analysis. The framework was developed through ICLEI's Urban $\mathrm{CO}_{2}$ Reduction Project and ten years of collaboration with cities from around the world to develop a standardized approach to emissions analysis. The framework tracks $\mathrm{CO}_{2}$ emissions from fuels, electricity, and waste (ICLEI and Torrie Smith Associates, 1999). The framework is supported by two 
software tools: 1) Cities for Climate Protection: Greenhouse Gas Emissions Software and 2) e-Mission: Greenhouse Gas Strategy Software.

\section{Cities for Climate Protection - Greenhouse Gas Emissions Software}

The Cities for Climate Protection (CCP) software has two packages: one for businesses and local governments to make their own inventories and another to assess community plans for reducing GHG emissions. The CCP software provides default national-level emissions factors for 1990 through 1998 for electricity. Location-specific electricity $\mathrm{CO}_{2}$ emissions factors for the inventories can be calculated using local utility bills and records. The CCP software has been distributed to over 300 cities in Australia, Canada, the UK, and the U.S. and there are currently about 200 active users. The software will soon be available in a Spanish version, possibly available in a Portuguese version, and will soon be distributed in South Africa, Indonesia, the Philippines, and Latin America (Torrie, 2001; Torrie Smith Associates, 2001a).

\section{e-Mission: Greenhouse Gas Strategy Software}

The e-Mission software was developed to provide a more robust method for businesses and communities to calculate inventories and track their GHG emissions. This tool provides a simple method for inputting a business's energy consumption and then uses default electricity and fuel $\mathrm{CO}_{2}$ emissions factors. The software tool designates default electricity coefficients for 1990-1997 based on modifications to the EIA state-level emissions factors for each state. Businesses can also insert their own electricity coefficients using local utility information. On-site cogeneration is treated as a fuelswitching measure in the software that typically saves grid electricity but adds emissions from the fuel used for cogeneration. Also, when making the inventory, businesses input annual kWh for "electricity" and for "green electricity" separately. This software has only recently been distributed and there are currently between 10 and 20 businesses using it (Torrie, 2001; Torrie Smith Associates, 2001b).

\section{NATIONAL APPROACHES}

\section{Australia-Greenhouse Challenge}

In 1995, Australia established the Greenhouse Challenge under the administration of the Australian Greenhouse Office. The Greenhouse Challenge is a voluntary initiative between the national government and industry to reduce, monitor and report direct and indirect GHG emissions. The program is flexible in that it allows industry to develop methods to reduce GHGs while the government provides technical support.

The Greenhouse Challenge Factors and Methods workbook offers participants useful formulas and factors to estimate emissions from a wide variety of sources, including use of purchased electricity. The Australian approach uses an annual AEF differentiated by state or territory. There is no attempt to adjust for variation in generation sources by season or time of day. A method for calculating electricity $\mathrm{CO}_{2}$ emissions for generation 
of electricity for public/private usage is included. This method provides a full fuel cycle EF by state or territory (AGO, 2000; AGO, 2001).

\section{Canada - Voluntary Challenge Registry}

Canada's Voluntary Challenge Registry was established in 1995 as part of the National Action Program on Climate Change. The registry works with the private and public sector to report both direct and indirect greenhouse gas emissions. In 1997 the Registry became an independent organization and now receives two-thirds of its funding from the private sector and the remainder from the government. Companies are encouraged to report entity-wide emissions, and can decide to report emissions of "individual subsidiaries, business units, facilities or even projects" (VCR-MRV, Inc., 1999). Although there is some flexibility on the base year, the preferred base year is 1990. The reporting system also encourages reporting of business-as-usual projections, targets, and measures to achieve targets, which can include forestry and land use activities that sequester carbon.

Emissions factors for electricity based on average annual net generation emissions factors for each province are provided by the Registry. However, companies may also use custom $\mathrm{CO}_{2}$ emissions factors based on utility emissions factors, as provided annually by the Canadian electric utilities. Companies are free to choose whether to use average or marginal electricity emissions factors; the Registry will review each company's reported values, but will not challenge this choice. Finally, companies can also account for electricity generated by on-site cogeneration. This includes calculating the emissions factor for the cogenerated electricity based on the fuel used as well as excluding exports of self-generated electricity (Rawson, 2001).

\section{United States - National Greenhouse Gas Inventory}

The U.S. Environmental Protection Agency prepares a national inventory of GHGs annually to comply with its commitment under the UN Framework Convention on Climate Change to submit annual National Communications (U.S. EPA, 2001a). The inventory calculates GHG emissions using methods consistent with those recommended by the IPCC (IPCC, 1996), but also expands upon the default emissions factors.

$\mathrm{CO}_{2}$ emissions from electricity are calculated using national utility fuel use information and carbon coefficients "derived by EIA from detailed fuel information" that are "similar to the carbon content coefficients contained in the IPCC's default method, with modifications reflecting fuel qualities specific to the United States." These emissions from electric utilities are then distributed to the end-use sectors based on their annual electricity consumption. This type of distribution can overestimate or underestimate sectoral emissions due to differences in average utility fuel mix carbon content. Nonutility generators of electricity (e.g., independent power producers and cogenerators) are not included in the electricity sector in the U.S. inventory, but rather are categorized as part of the industrial sector. Emissions from these electricity generators are estimated separately by the U.S. Department of Energy and the U.S. Environmental Protection 
Agency. This report provides emissions from utility and non-utility electric generators by Census regions (U.S. DOE and U.S. EPA, 2000).

\section{United States - Voluntary Reporting of Greenhouse Gases Program - 1605(b)}

The Voluntary Reporting of Greenhouse Gases Program (VRGGP) was created under Title XVI, Section 1605(b) of the Energy Policy Act of 1992 to register and report the results of voluntary activities to "reduce, avoid, or sequester greenhouse gas emissions." The program is administered by the Energy Information Administration (EIA) of the U.S. Department of Energy. Emission reductions can be made on an entity level and a project level, including carbon sequestration projects. Entity-level reporting is encouraged. In 1999, 201 companies reported project-level emissions representing 226 million metric tons of $\mathrm{CO}_{2}$ equivalent. That same year 78 companies reported entity-level emissions representing 1.5 billion metric tons (U.S. DOE, EIA, 2001b).

Participants are required to report $\mathrm{CO}_{2}$ emissions from purchased electricity. In order to calculate these emissions, a state level AEF is provided. However, this factor does not include emissions from power produced by non-utility generators. The Program characterizes these state level emissions factors as "reasonably accurate default values" but also notes that reporters should only use these state-level factors if utility-specific or power-pool specific emissions factors are not available (U.S. DOE/EIA, 2001b).

\section{United States - Climate Leaders Program}

The Climate Leaders Program is a new EPA initiative to promote voluntary corporatewide GHG reductions. EPA aims to create a "credible and verifiable" system that can be used as a standard model by all state registries. Companies are required to report all direct emissions as well as indirect emissions related to electricity use. Emissions from all domestic facilities are required; however, companies can also include emissions and reductions from international facilities. Additionally, companies can claim reductions from transportation programs and carbon sequestration measures. The program is in the pilot phase and is being tested by seven companies (U.S. EPA 2001b).

EPA encourages participants to obtain electricity emissions factor information directly from the electricity provider. If this information is not available, electricity emissions factors can be calculated using the state default emissions factor from the E-GRID database. In the future, the E-GRID database will be able to give emissions factors based on a sub-NERC region. When this information is available, the Program will recommend that companies use these values instead of the state averages (U.S. EPA, 2001c).

\section{STATE APPROACHES}

\section{Emission Inventory Improvement Program}

Emission Inventory Improvement Program (EIIP), an effort designed to determine standard methodologies for performing air emissions inventories, sponsored in part by the 
U.S. EPA and the State and Territorial Air Pollution Program Administrators/Association of Local Air Pollution Control Officials (STAPPA/ALAPCO). The goal of the program is to "provide cost effective, reliable inventories by improving the quality of emissions information and developing systems for collecting, calculating, and reporting emissions data" (U.S. EPA, 2001d). Estimating Greenhouse Gas Emissions (EIIP 1999) is an EIIP report that includes a method for calculating GHG emissions and builds on EPA's earlier method outlined in the State Workbook: Methods for Estimating Greenhouse Gas Emissions. The EIIP method developed to identify and estimate GHGs is adapted from the IPCC Guidelines (IPCC, 1996).

Following EIIP guidelines, two approaches can be used to determine emissions from electricity use. States can estimate fuel consumption from the electric generation sector or estimate electricity consumption by the major fuel-consuming sectors (residential, commercial, industrial, transportation). If specific information is unavailable, default values of the percentage of electricity consumed by the major sectors can be found in the State Energy Data Report, an EIA publication. It is suggested that states utilize state- or region-specific emissions factors or "take on-site emission measurements at various sources." Methods used for calculating emissions factors must be clearly identified.

Regarding electricity exported from one state to another, the EIIP method directs that "each state should count the $\mathrm{CO}_{2}$ emissions from all electricity generation in the state, regardless of where the electricity is ultimately used." Even so, the EIIP includes a method for calculating emissions from net imports of electricity using a national average emission rate or a state-specific emission rate that accounts for electricity imported and exported from the state. The state-specific EF assumes that electricity imports represent an average mix of electricity fuel sources from the exporting state. According to this report, as of 1999, no method has yet been developed to accurately calculate marginal emission rates (EIIP, 1999).

\section{State Greenhouse Gas Inventories}

The State and Local Outreach Program of the U.S. EPA works with states to develop GHG inventories and action plans using the methods outlined by the EIIP as described above. Thirty-four states and Puerto Rico have completed inventories; another two states have inventories in progress. Each inventory identifies the major sources of GHG emissions and presents annual emissions of GHGs by sector (e.g., energy, agriculture, waste), by source (e.g., transportation emissions, manure management), and by gas (e.g., carbon dioxide, methane). GHG emissions are estimated as a function of (a) activity data (e.g., electricity usage, cement production, fertilizer consumption, etc.) and (b) activityand gas-specific emissions factors (U.S. EPA, 2001e). The California inventory is described in more detail below.

California - Historical and Forecasted Greenhouse Gas Emissions Inventories for California

The CEC has published a state level GHG inventory that covers the period 1990 to 1994 (CEC 1998). A forthcoming revision will update the inventory to 1999 (CEC, 2001c). 
The emissions are calculated according to the EPA guidelines articulated in the State Workbook: Methods for Estimating Greenhouse Gas Emissions, except where more precise methods or specific data were available. Total California GHG emissions for 1990 were in excess of 456 million tons of $\mathrm{CO}_{2}$ equivalent and increased slightly to 458 million tons by 1994 . Of this, $\mathrm{CO}_{2}$ accounted for approximately 400 million tons with electricity generation responsible for about $16 \%$. This percentage is much lower than the national average due to the lower carbon fuel mix of California electricity and low per capita electricity consumption (EEI 1999).

Emissions associated with fossil fuel combustion are calculated according to fuel mix and carbon content of fuels. The CEC inventory includes emissions from both utility and nonutility electric generating plants. GHG emissions from electricity imports are not counted as part of the in-state GHG emission inventory, which is in agreement with EPA guidelines. However, the CEC inventory reported the carbon dioxide emissions associated with production from out-of-state power plants serving California in 1990. These emissions levels were higher than the emissions associated with in-state power plants.

\section{Wisconsin}

Wisconsin's greenhouse gas registry legislation was passed in May of 2000 (Senate Bill 287 Section 285.78) (Mosher 2001; Wisconsin Senate 1999). The registry, maintained by the Department of Natural Resources, will account for GHG emissions as well as toxic pollutants including mercury and lead. The rules governing Wisconsin's registry are based on the federal 1605(b) GHG guidelines so the EFs used are drawn from the VRGGP.

\section{New Jersey}

Initially established by the Department of Environmental Protection to reduce toxic air emissions, the Open Market Emissions Trading Program (OMET) was revised in June 2000 (under Amendment N.J.A.C 7:27-30) to include greenhouse gas emissions. New Jersey's registry is voluntary and project-based in accordance with the federal $1605(\mathrm{~b})$ legislation. New Jersey does not currently have official guidance on calculating emissions factors. However, the New Jersey Department of Environmental Protection is planning on using E-GRID or other publicly available information to determine the state's average emission rates and fuel mix to calculate an emissions factor (Chen 2001).

\section{New Hampshire}

New Hampshire passed legislation to establish a GHG registry in 1999. This bill aims to form "a registry for voluntary greenhouse gas emission reductions in order to create an incentive for and reward those greenhouse gas sources which voluntarily reduce such emissions before required to do so." (NHGC, 1999) This registry is also based on the federal 1605(b) guidelines, and EFs are likely to be calculated from the state's average emissions rates and fuel mix (Colburn, 2001). 


\section{E. NON-GOVERNMENTAL ORGANIZATION APPROACHES}

\section{Greenhouse Gas Protocol Initiative}

The Greenhouse Gas Protocol Initiative (GHGPI), a joint project of the World Resources Institute and World Business Council for Sustainable Development, is a collaborative effort to develop a standard GHG reporting method for emissions from business entities. This protocol is being developed in association with UNEP's indicator described above in section II.B.1. Current participants in the "road test" phase of the protocol include DuPont, British Petroleum, Ford Motor Company, and IBM among others. The EPA's Climate Leaders program has also chosen the GHGPI guidelines as a model for several reasons. The method is compatible with IPCC guidelines, has received input from both the public and private sector, and has been reviewed by experts and stakeholders. Moreover, the method is relatively simple and standardized (GHGPI, 2000; GHGPI, 2001).

The GHGPI protocol consists of three main modules with each covering a different scope of emissions. The first module, the corporate inventory module, is the one most relevant to emissions from electricity. It allows for three levels of reporting. The first level, Scope 1 , requires reporting of all direct (on-site) GHG emissions. Scope 2 encompasses Scope 1 as well as GHG emissions from imports of electricity, heat, or steam. Scope 3 includes other indirect GHG emissions such as employee business travel, transportation of products, materials, and waste, outsourced activities, contract manufacturing, etc. Scope 2 instructions do not provide an electricity emissions factor method. Instead, companies are encouraged to use an average emissions factor $\left(\mathrm{CO}_{2} / \mathrm{kWh}\right)$ provided by the electricity supplier or to work with suppliers to develop a custom emissions factor associated with the company's usage. Where this is not feasible, companies are encouraged to use a government-published default emissions factor for the region, state, or nation (GHGPI 2001).

\section{Environmental Resources Trust}

Environmental Resources Trust, founded in 1996 by Environmental Defense, has created a GHG registry program for project-level corporate emissions (ERT 2001). The goal of the program is to build an infrastructure for a carbon market and to encourage early action by companies. However, ERT's registry tracks only direct emissions, with no accounting for emissions associated with electricity use. Instead, these emissions are allocated to the electricity generators, who can then trade credits from reductions as part of ERT's registry. ERT plans to eventually link the direct emissions in their database with state registries. In order to be compatible with state registries, ERT has adopted standard measurement protocols such as the guidelines for Scope 1 in the GHGPI report. 


\section{F. Published CALIfornia Electricity EMissions FaCtors}

A number of the GHG inventories, registries, and protocols discussed above provide annual average electricity emissions factors for California. ${ }^{22}$ These values, and a tabulation of what is and is not included in the calculations, are provided in Table 3. As shown, the reported AEFs vary significantly due not only to different reporting years, but also to whether imports, exports, out-of-state generation and non-utility generation are included. These electricity emissions factors are the only factors currently available to quantify $\mathrm{CO}_{2}$ emissions associated with electricity generation.

\footnotetext{
${ }^{22}$ None of the published sources provide marginal electricity emissions factors, factors for utility service districts, or monthly emissions factors.
} 
Table 2. Characteristics of Greenhouse Gas Inventories, Registries, and Protocols

\begin{tabular}{|c|c|c|c|c|c|}
\hline Name & $\begin{array}{l}\text { Scope of Emissions } \\
\text { Sources }{ }^{1} \text { and Sinks }{ }^{2} \\
\end{array}$ & $\begin{array}{l}\text { Reporting } \\
\text { Scope }^{3}\end{array}$ & Electricity Emissions Factor & Participation Rate & Comments \\
\hline \multicolumn{6}{|l|}{ INTERNATIONAL } \\
\hline $\begin{array}{l}\text { IPCC Guidelines for } \\
\text { National GHG Inventories } \\
\text { (IPCC }, 1996)\end{array}$ & $\begin{array}{l}\text { Direct emissions } \\
\text { Indirect emissions } \\
\text { Sinks }\end{array}$ & National & $\begin{array}{l}\text { Default global EFs provided } \\
\text { for all fuel types, no specific } \\
\text { electricity EFs. }\end{array}$ & $\begin{array}{l}\text { National } \\
\text { Communications: } \\
35 \text { Annex I } \\
\text { countries } 51 \text { non- } \\
\text { Annex I countries } \\
\end{array}$ & $\begin{array}{l}\text { Internationally } \\
\text { accepted, but does } \\
\text { not provide } \\
\text { electricity EFs }\end{array}$ \\
\hline $\begin{array}{l}\text { UNEP GHG Indicator } \\
\text { (Thomas et al., 2000) }\end{array}$ & $\begin{array}{l}\text { Direct emissions } \\
\text { Indirect emissions }\end{array}$ & Business & $\begin{array}{l}\text { Default national EFs for } \\
\text { electricity for } 1990 \text { and } 1996 \\
\text { based on IEA data. Users are } \\
\text { recommended to use national } \\
\text { EFs if known. EFs for CHP- } \\
\text { generated electricity included. }\end{array}$ & $\begin{array}{l}\text { Being used as a } \\
\text { part of many } \\
\text { national and } \\
\text { international efforts } \\
\text { (e.g. } \\
\text { WRI/WBCSD, } \\
\text { EBRD, Blue Circle } \\
\text { Industries) }\end{array}$ & $\begin{array}{l}\text { Deals with imports } \\
\text { and exports of } \\
\text { CHP-produced } \\
\text { electricity. }\end{array}$ \\
\hline $\begin{array}{l}\text { International Council for } \\
\text { Local Environmental } \\
\text { Initiatives - Cities for } \\
\text { Climate Protection } \\
\text { (Torrie Smith Associates, } \\
\text { 2001a) }\end{array}$ & $\begin{array}{l}\text { Direct emissions } \\
\text { Indirect emissions }\end{array}$ & Municipal & $\begin{array}{l}\text { Default national and state EFs } \\
\text { or users calculate EFs based } \\
\text { on local utility information }\end{array}$ & $\sim 200$ cities & \\
\hline $\begin{array}{l}\text { International Council for } \\
\text { Local Environmental } \\
\text { Initiatives - } \\
\text { e-Mission: Greenhouse } \\
\text { Gas Strategy Software } \\
\text { (Torrie Smith Associates, } \\
\text { 2001b) }\end{array}$ & $\begin{array}{l}\text { Direct emissions } \\
\text { Indirect emissions }\end{array}$ & Business & $\begin{array}{l}\text { Default national and state EFs } \\
\text { or users calculate EFs based } \\
\text { on local utility information. } \\
\text { CHP-generated electricity } \\
\text { included. }\end{array}$ & 10-20 businesses & $\begin{array}{l}\text { Relatively new } \\
\text { software. }\end{array}$ \\
\hline \multicolumn{6}{|l|}{ NATIONAL } \\
\hline $\begin{array}{l}\text { Australia - Greenhouse } \\
\text { Challenge } \\
(A G O, 2001)\end{array}$ & $\begin{array}{l}\text { Direct emissions } \\
\text { Indirect emissions } \\
\text { Sinks }\end{array}$ & Business & $\begin{array}{l}\text { Default annual average EF } \\
\text { differentiated by state or } \\
\text { territory. }\end{array}$ & $\begin{array}{l}\text { Electricity } \\
\text { generators and } \\
\text { more than } 500 \\
\text { members. }\end{array}$ & \\
\hline
\end{tabular}




\begin{tabular}{|c|c|c|c|c|c|}
\hline Name & $\begin{array}{l}\text { Scope of Emissions } \\
\text { Sources }^{1} \text { and Sinks } \\
\end{array}$ & $\begin{array}{l}\text { Reporting } \\
\text { Scope }^{3} \\
\end{array}$ & Electricity Emissions Factor & Participation Rate & Comments \\
\hline $\begin{array}{l}\text { Canada - Voluntary } \\
\text { Challenge and Registry, } \\
\text { Inc. } \\
\text { (VCR-MRV, Inc., 1999) }\end{array}$ & $\begin{array}{l}\text { Direct emissions } \\
\text { Indirect emissions }\end{array}$ & $\begin{array}{l}\text { Business } \\
\text { Project }\end{array}$ & $\begin{array}{l}\text { Default EFs based on average } \\
\text { annual net generation for each } \\
\text { province are provided by the } \\
\text { Registry. Companies may } \\
\text { also generate custom } \\
\text { emissions factors using local } \\
\text { utility information. CHP- } \\
\text { generated electricity included. }\end{array}$ & $\begin{array}{l}775 \text { companies } \\
\text { have reported. }\end{array}$ & \\
\hline $\begin{array}{l}\text { United States - National } \\
\text { Greenhouse Gas } \\
\text { Inventory } \\
\text { (U.S. EPA, 2001a) }\end{array}$ & $\begin{array}{l}\text { Direct emissions } \\
\text { Indirect emissions }\end{array}$ & National & $\begin{array}{l}\text { EFs derived by EIA from } \\
\text { detailed fuel information, but } \\
\text { calculated only by census } \\
\text { region. }\end{array}$ & & $\begin{array}{l}\text { Emissions from } \\
\text { non-utility } \\
\text { generation are } \\
\text { reported in the } \\
\text { industrial sector. }\end{array}$ \\
\hline $\begin{array}{l}\text { United States - Voluntary } \\
\text { Reporting of Greenhouse } \\
\text { Gases Program - 1605(b) } \\
\text { (U.S. DOE/EIA, 2001a) }\end{array}$ & $\begin{array}{l}\text { Direct emissions } \\
\text { Indirect emissions } \\
\text { Sinks }\end{array}$ & $\begin{array}{l}\text { Business } \\
\text { Project }\end{array}$ & $\begin{array}{l}\text { State-level default EFs } \\
\text { provided. Utility-specific or } \\
\text { power pool-specific EFs } \\
\text { preferred. }\end{array}$ & $\begin{array}{l}201 \text { companies in } \\
1999 .\end{array}$ & $\begin{array}{l}\text { Emissions from } \\
\text { non-utility } \\
\text { generators not } \\
\text { included. }\end{array}$ \\
\hline $\begin{array}{l}\text { United States - Climate } \\
\text { Challenge } \\
\text { (U.S. DOE, 1996) }\end{array}$ & $\begin{array}{l}\text { Direct emissions } \\
\text { Indirect emissions } \\
\text { Sinks } \\
\end{array}$ & $\begin{array}{l}\text { Business } \\
\text { Project }\end{array}$ & & $\begin{array}{l}\text { Participation of } \\
\text { over } 650 \text { utilities. }\end{array}$ & $\begin{array}{l}\text { Only includes } \\
\text { utilities. }\end{array}$ \\
\hline $\begin{array}{l}\text { United States - Climate } \\
\text { Leaders Program } \\
\text { (U.S. EPA, 2001b) }\end{array}$ & $\begin{array}{l}\text { Direct emissions } \\
\text { Indirect emissions } \\
\text { Sinks }\end{array}$ & Business & $\begin{array}{l}\text { EFs from utility-specific } \\
\text { information preferred or use } \\
\text { E-GRID database state-level } \\
\text { defaults. }\end{array}$ & $\begin{array}{l}\text { Pilot phase with } 7 \\
\text { companies. }\end{array}$ & $\begin{array}{l}\text { Will use sub-NERC } \\
\text { regions from E- } \\
\text { GRID as defaults in } \\
\text { the future. }\end{array}$ \\
\hline \multicolumn{6}{|l|}{ STATE } \\
\hline $\begin{array}{l}\text { Emission Inventory } \\
\text { Improvement Program } \\
\text { (EIIP, 1999) } \\
\text { State Greenhouse Gas } \\
\text { Inventories } \\
\text { (U.S. EPA, 2001e) }\end{array}$ & $\begin{array}{l}\text { Direct emissions } \\
\text { Indirect emissions }\end{array}$ & State & $\begin{array}{l}\text { State- or region-specific } \\
\text { emissions factors } \\
\text { recommended or use on-site } \\
\text { emissions measurements. }\end{array}$ & $\begin{array}{l}34 \text { states and } \\
\text { Puerto Rico have } \\
\text { inventories; } 2 \text { states } \\
\text { have inventories in } \\
\text { progress. }\end{array}$ & $\begin{array}{l}\text { Provides method to } \\
\text { account for imports } \\
\text { and exports. }\end{array}$ \\
\hline
\end{tabular}




\begin{tabular}{|c|c|c|c|c|c|}
\hline Name & $\begin{array}{l}\text { Scope of Emissions } \\
\text { Sources }{ }^{1} \text { and Sinks }{ }^{2}\end{array}$ & $\begin{array}{l}\text { Reporting } \\
\text { Scope }^{3}\end{array}$ & Electricity Emissions Factor & Participation Rate & Comments \\
\hline $\begin{array}{l}\text { California Inventory of } \\
\text { Greenhouse Gas } \\
\text { Emissions } \\
(\mathrm{CEC}, 1998)\end{array}$ & $\begin{array}{l}\text { Direct emissions } \\
\text { Indirect emissions }\end{array}$ & State & $\begin{array}{l}\text { Based on EPA State } \\
\text { Greenhouse Gas Inventories } \\
\text { methods. }\end{array}$ & & $\begin{array}{l}\text { Includes emissions } \\
\text { from non-utility } \\
\text { generators. Does } \\
\text { not include } \\
\text { electricity imports. }\end{array}$ \\
\hline $\begin{array}{l}\text { Wisconsin } \\
\text { (Mosher, 2001) }\end{array}$ & $\begin{array}{l}\text { Direct emissions } \\
\text { Indirect emissions } \\
\text { Sinks }\end{array}$ & $\begin{array}{l}\text { Business } \\
\text { Project }\end{array}$ & State-level EFs from EIA. & Not yet established. & $\begin{array}{l}\text { Based on federal } \\
1605(b) \text { program. }\end{array}$ \\
\hline $\begin{array}{l}\text { New Jersey } \\
\text { (Chen, 2001) }\end{array}$ & $\begin{array}{l}\text { Direct emissions } \\
\text { Indirect emissions }\end{array}$ & Project & $\begin{array}{l}\text { No official EFs provided. In } \\
\text { future will calculate EFs } \\
\text { using E-GRID or other } \\
\text { publicly available information } \\
\text { to determine a state average } \\
\text { EF. }\end{array}$ & & $\begin{array}{l}\text { Based on federal } \\
1605 \text { (b) program. }\end{array}$ \\
\hline $\begin{array}{l}\text { New Hampshire } \\
\text { (Colburn, 2001) }\end{array}$ & $\begin{array}{l}\text { Direct emissions } \\
\text { Indirect emissions }\end{array}$ & Project & $\begin{array}{l}\text { State-level EFs to be } \\
\text { calculated from state average } \\
\text { emissions rates and fuel mix. }\end{array}$ & Not yet established. & $\begin{array}{l}\text { Based on federal } \\
1605 \text { (b) program. }\end{array}$ \\
\hline \multicolumn{6}{|l|}{ NON-GOVERNMENTAL } \\
\hline $\begin{array}{l}\text { Greenhouse Gas Protocol } \\
\text { Initiative } \\
\text { (GHGPI, 2001) }\end{array}$ & $\begin{array}{l}\text { Direct emissions } \\
\text { Indirect emissions } \\
\text { Sinks }\end{array}$ & $\begin{array}{l}\text { Business } \\
\text { Project }\end{array}$ & $\begin{array}{l}\text { Users encouraged to calculate } \\
\text { average EF from electricity } \\
\text { supplier information or work } \\
\text { with supplier to develop } \\
\text { custom EF. } \\
\text { Users may also use default } \\
\text { EF for region, state, nation. }\end{array}$ & $\begin{array}{l}30 \text { pilot phase } \\
\text { "road test" } \\
\text { participants. }\end{array}$ & $\begin{array}{l}\text { Final guidelines } \\
\text { issued 10/01. }\end{array}$ \\
\hline $\begin{array}{l}\text { Environmental Resources } \\
\text { Trust } \\
\text { (ERT, 2001) }\end{array}$ & Direct emissions & $\begin{array}{l}\text { Business } \\
\text { Project }\end{array}$ & $\begin{array}{l}\text { Indirect emissions not } \\
\text { reported. }\end{array}$ & $\begin{array}{l}>100 \mathrm{MtCO}_{2} \\
\text { equivalent under } \\
\text { management. }\end{array}$ & \\
\hline
\end{tabular}

${ }^{1}$ Sources $=$ Direct emissions (fuels, process-related) and indirect emissions (electricity).

2 Sinks $=$ Carbon offsets and sequestration.

3 Reporting scope can be at the national, state, municipal, business (includes non-commercial organizations such as universities), or project level. 
Table 3. Comparison of Published Average Annual Electricity $\mathrm{CO}_{2}$ Emissions Factors for California

\begin{tabular}{|c|c|c|c|c|c|c|c|c|c|}
\hline Source & Year(s) & $\begin{array}{c}\text { Average } \\
\text { Emission } \\
\text { Factor } \\
(\mathbf{k g C} / \mathbf{k W h})\end{array}$ & $\begin{array}{c}\text { Includes } \\
\text { Utility-Owned } \\
\text { In-State } \\
\text { Generation }\end{array}$ & $\begin{array}{c}\text { Includes } \\
\text { Utility-Owned } \\
\text { Out-Of-State } \\
\text { Generation }\end{array}$ & $\begin{array}{c}\text { Includes } \\
\text { Non-Utility } \\
\text { Generation }\end{array}$ & $\begin{array}{l}\text { Includes } \\
\text { Imports }\end{array}$ & $\begin{array}{l}\text { Includes } \\
\text { Exports }\end{array}$ & $\begin{array}{c}\text { Excludes } \\
\text { Specific } \\
\text { Purchases }\end{array}$ & Comments \\
\hline $\begin{array}{l}\text { Voluntary } \\
\text { Reporting of } \\
\text { GHGs }-1605(\mathrm{~b})^{1}\end{array}$ & $1997-99$ & 0.037 & $\mathrm{Y}$ & $\mathrm{N}$ & $\mathrm{N}$ & $\mathrm{N}$ & $\mathrm{N}$ & $\mathrm{N}$ & \\
\hline $\begin{array}{l}\text { Voluntary } \\
\text { Reporting of } \\
\text { GHGs }-1605(b) \\
1\end{array}$ & 1992 & 0.094 & $\mathrm{Y}$ & $\mathrm{N}$ & $\mathrm{Y}$ & $\mathrm{N}$ & $\mathrm{N}$ & N/A & $\begin{array}{l}\text { Might include non- } \\
\text { utility and/or imports } \\
\text { - documentation } \\
\text { unclear }\end{array}$ \\
\hline $\begin{array}{l}\text { ICLEI - e- } \\
\text { Mission: GHG } \\
\text { Strategy } \\
\text { Software }^{2}\end{array}$ & 1998 & 0.125 & $\mathrm{Y}$ & $\mathrm{N}$ & $\mathrm{N}$ & $\mathrm{Y}$ & $\mathrm{N}$ & $\mathrm{N}$ & $\begin{array}{l}\text { Data drawn from } \\
\text { DOE's State Energy } \\
\text { Data Report; } \\
\text { emissions from } \\
\text { imports calculated } \\
\text { using U.S. average } \\
\text { EF }\end{array}$ \\
\hline $\begin{array}{l}\text { U.S. EPA } \\
\text { National GHG } \\
\text { Inventory }^{3}\end{array}$ & 1998 & 0.052 & $\mathrm{Y}$ & $\mathrm{N}$ & $\mathrm{Y}$ & $\mathrm{N}$ & $\mathrm{N}$ & $\mathrm{N}$ & $\begin{array}{l}\text { EF is for the Pacific } \\
\text { Contiguous Census } \\
\text { Division which } \\
\text { includes Washington } \\
\text { and Oregon }\end{array}$ \\
\hline $\begin{array}{l}\text { Emissions } \\
\text { Inventory } \\
\text { Improvement } \\
\text { Program } \\
\end{array}$ & 1995 & 0.114 & $\mathrm{Y}$ & $\mathrm{Y}$ & $\bar{Y}$ & $\mathrm{Y}$ & $\mathrm{N}$ & $\mathrm{N} / \mathrm{A}$ & \\
\hline $\begin{array}{l}\text { California } \\
\text { Inventory of } \\
\text { GHG Emissions } \\
\end{array}$ & 1994 & 0.093 & $\mathrm{Y}$ & $\mathrm{N}$ & $\mathrm{Y}$ & $\mathrm{N}$ & $\mathrm{N}$ & N/A & \\
\hline E-GRID $^{6}$ & 1998 & 0.059 & $\mathrm{Y}$ & $\mathrm{N}$ & $\mathrm{Y}$ & $\mathrm{N}$ & $\mathrm{N}$ & $\mathrm{N}$ & \\
\hline
\end{tabular}


http://www.eia.doe.gov/cneaf/electricity/page/co2_report/co2report.html

4 U.S. EPA. 1999. Estimating Greenhouse Gas Emissions. Vol. VIII: Chapter 1 "Methods for Estimating Carbon Dioxide Emissions from Combustion of Fossil Fuels." http://www.epa.gov/ttnchie1/eiip/ techreport/volume08/index.html

5 California Energy Commission. 1998. 1997 Global Climate Change: Greenhouse Gas Emissions Reduction Strategies for California. Appendix A: Historical and Forecasted GHG Emissions Inventories for California. Sacramento, CA: California Energy Commission

6 LBNL calculation using EPA's E-GRID plant-level data on $\mathrm{CO}_{2}$ emissions and net generation. See U.S. EPA 2001c. E-GRID 2000.

http://www.epa.gov/airmarkets/egrid/index.html 


\section{G. STANDARDS ADOPTED IN THIS STUDY}

As stated in section I.B, the purpose of this project is to explore various approaches to estimating AEFs and MEFs that can translate the electricity use of California consumers into a net $\mathrm{CO}_{2}$ emissions responsibility. Thus, standards used in inventories, where the boundary of emissions accounting is geographically defined, will differ from standards used here. For example, the current Greenhouse Gas Emissions Inventories for California (CEC, 2001c) follows the EPA Guidelines (U.S. EPA, 1999). In this section, we review some of the key differences between this work and inventory approaches. Standards specific to one of the three methods are described in the subsequent sections treating those approaches.

One major difference between the standards used for this report and the EPA Guidelines (U.S. EPA, 1999) concerns the treatment of exported and imported power. Since these guidelines concern a geographic inventory, they focus on accounting for in-state emissions. Additionally, they cite the daunting problem of tracing electricity consumed to where it was generated, by what fuel, and at what efficiency, they conclude that estimating GHG emissions at the point of generation is the most accurate approach (U.S. EPA, 1999). The only adjustment suggested by the EPA for interstate trade of electricity is based on the average annual U.S. $\mathrm{CO}_{2}$ emissions rate for power generation. Note that the 1998 inventory of GHG emissions in California only treats emissions from generation of electricity within California state borders (CEC, 1998), whereas the goal here is to estimate the $\mathrm{CO}_{2}$ emissions burden of end-use customers. ${ }^{23}$

In order to do this for California, it is critical to account for imported electricity. California imports far more electricity than it exports, and much of the imported electricity comes from the Southwest, a region that relies heavily on coal-fired generation. Thus, while imports accounted for about one third of electricity consumption in California, the imported electricity was responsible for over half of the emissions. ${ }^{24}$ The preponderance of coal as the fuel for electricity imported into California also stems from the fact some of California's UDCs own coal burning generating stations outside of state borders, for example the Mohave station in Nevada, which is partially owned and operated by SCE. Overall, it is estimated that almost $20 \%$ of electricity consumed in California in 1999 was generated from coal-fired power plants (CEC, 2001a).

\footnotetext{
${ }^{23}$ The goal of this exercise is to associate emissions at the power plant with consumption at the outlet, making the best available ratio: emissions at the plant per $\mathrm{kWh}$ measured at the customer meter. Unfortunately, the definitions of sales that are used in various sources are not consistent. For example, Elfin data files include energy that is not delivered to ultimate customers but to other distributors. For fear of introducing an unnecessary inaccuracy into our calculations, generation has been used rather than sales as our denominator. Generation data is much more clearly and consistently defined and readily available. The difference between the two is the losses that occur in T\&D. In general, these losses are about $8 \%$ of generation (CEC, 2000) and this adjustment could be readily made to results, as a simple adjustment pending a closer review of sales information.

${ }^{24}$ This figure is from calculations performed in this report based on data from the EIA Forms 759 and 860B. See section III.E and Table 10 in particular.
} 
In this study, Berkeley Lab has also derived EFs for individual UDCs since the generation mixes of California's UDCs vary significantly. PG\&E has a relatively carbonfree resource mix. It controls considerable hydro resources in northern California (about 60 percent of the state total), owns and operates a large nuclear station, and imports significant hydro generated electricity from the Pacific Northwest. The net result of these factors leads to a significantly lower coal share in PG\&E's fuel mix and a lower average carbon emissions factor. In contrast, LADWP imports most of its electricity from coalfired stations in the Southwest that it partially owns, as well as from other Southwest power providers. By the estimates of the Elfin approach the AEF for LADWP in 1990 was $0.195 \mathrm{kgC} / \mathrm{kWh}$, while the equivalent for PG\&E was only $0.070 \mathrm{kgC} / \mathrm{kWh}$. Due to the range of emissions factors among California's UDCs, considerable effort is made to estimate emissions factors by electricity utility, which is rarely the case for emissions inventories.

Since load data (particularly the hourly load data required for the LDC model) were only available for entire PCAs, calculations include the smaller utilities (generally munis) that are embedded in the PCAs of larger distribution companies. Moreover, without detailed sales information, it is impossible to differentiate the sources of the embedded utilities' power from those sources feeding the entire PCA.

No attempt is made in this work to account for upstream emissions related to power generation. Extraction and delivery of fossil fuels causes significant emissions of combustion products, notably $\mathrm{CO}_{2}$, that emerge in myriad ways such as from extraction and cleaning of fuel, combustion in trains and trucks that deliver fuels, operations and accidental fires at mines, etc. One estimate is that the carbon emissions upstream are equivalent to $5.2 \%$ of combustion emissions for coal, and $17.8 \%$ for natural gas (DeLucchi, 1997).

While the goal of the Registry is to track all GHG emissions, or at the least the six gases identified in the Kyoto Protocol, GHG emissions from the power sector are dominated by $\mathrm{CO}_{2}$. We focus on emissions of $\mathrm{CO}_{2}$ since emissions of the other GHGs from utilities are comparatively negligible. In 1999, U.S. electric utilities released approximately 532.6 million metric tons of carbon (MtC) but only $2.3 \mathrm{MtC}$ equivalent (Eq.) of nitrous oxide $\left(\mathrm{N}_{2} \mathrm{O}\right)$ and less than $0.1 \mathrm{MtC}$ Eq. of methane $\left(\mathrm{CH}_{4}\right) \cdot{ }^{25}$ Additionally, fugitive emissions of sulfur hexafluoride $\left(\mathrm{SF}_{6}\right)$ are released from substations and circuit breakers in the electrical transmission and distribution system. These emissions equaled approximately 7 MtC Eq. (U.S. EPA 2001a). In addition, it is difficult to estimate these emissions on the basis of generation or fuel consumption data.

In keeping with standard practice, all emissions of carbon are counted as kilograms of equivalent carbon $(\mathrm{kgC})$. The convention adopted here is to report all total emissions in $\mathrm{MtC}$, where one metric ton equals $1000 \mathrm{~kg}$, equivalent to $1.102311 \mathrm{U} . \mathrm{S}$. short tons (or

\footnotetext{
${ }^{25}$ Equivalents are based on the global warming potential (GWP) of a GHG, which is the ratio of radiative forcing (both direct and indirect) from one kilogram of GHG to one kilogram of $\mathrm{CO}_{2}$ over a period of time, in this case 100 years (U.S. DOE/EIA, 1997; IPCC, 1996).
} 
$2000 \mathrm{lbs}$.). Emissions factors are all reported in kilograms of equivalent carbon emitted at the generating station per kilowatt-hour of electricity generated $(\mathrm{kgC} / \mathrm{kWh})$. Electricity generation is reported in terawatthours (TWh), or billions of kilowatthours. All $\mathrm{CO}_{2}$ emissions incurred to generate electricity for California consumers are divided by the total state load, so that the resulting factor can estimate the actual $\mathrm{CO}_{2}$ emitted to the atmosphere as carbon equivalent at the power plant. If emissions are in $\mathrm{MtC}$ and generation in TWh, then the ratio of the two is $\mathrm{kgC} / \mathrm{kWh}$.

Since electricity customers' bills report usage at the meter, the factors reported here should be corrected to reflect the loss of power during transmission and distribution. Load data were used to more accurately estimate the total imports needed to meet demand and to provide greater consistency between the LDC and PDS methods. An adjustment can be made by dividing the EFs reported here by the average share of electricity in the load that reaches final consumers. For example, if average transmission and distribution losses are 8 percent, the factors would be adjusted by dividing them by 0.92 . 


\section{III.CALCULATING ELECTRICITY EMISSION FACTORS USING PUBLIC DATA SOURCES}

Berkeley Lab analyzed primary data from public sources to estimate AEFs. In this approach, federal and state data on electricity production, fuel consumption, and loads were used to estimate AEFs for both the entire state and individual PCAs. Each PCA's generation was summed from plant-level data, and data on fuel consumption were used to estimate $\mathrm{CO}_{2}$ emissions originating in the PCA. Each PCA's generation was subtracted from its load to approximate net imports. Regional AEFs were calculated for the Northwest and Southwest, and the $\mathrm{CO}_{2}$ emissions from imports were estimated using these factors.

\section{A. DESCRIPTION OF DATA SOURCES}

Drawing on the data sources described in Table 4, monthly and annual AEFs were estimated for the four largest PCAs (PG\&E, SCE, LADWP, and SDG\&E) as well as for the entire state. Berkeley Lab has developed an Excel spreadsheet to manage the large amounts of annual and monthly data from public sources relevant to calculating the AEFs from public domain data. Berkeley Lab assembled EIA and FERC data pertaining to electricity generation and fuel consumption for both the 1990 and 1999 test years, annual statewide generation and import data from the CEC, the Power Source Disclosure program's data on sales of green power, and monthly load data for 1999 from CAISO.

In addition to these data sources, the U.S. EPA has its own program to consolidate various sources of information regarding the power sector, the Emissions and Generations Resource Integrated Database (E-GRID). This database provides a comprehensive source of data on the environmental characteristics of all electric power generated in the United States (US EPA, 2001c). It integrates twenty-three different federal data sources and provides information on a wide range of power plant characteristics and operations, including air pollutant emissions and fuel consumption. Currently E-GRID covers the years 1996 to 1998. The 1999 version is scheduled for release in the summer of 2002. While this database is useful for calculations of annual inventories, it does not provide any monthly data and the current version does not contain any transmission information.

\section{B. DATABASE DEVELOPMENT}

\section{Utility Data}

Utility data were taken from Form 759 (US DOE/EIA, 2001f), monthly and annual databases, which provide plant-level detail on net generation and fuel consumption. For facilities using more than one fuel, the data are reported separately for each fuel. Plants operated by smaller utilities were matched to their respective PCAs using data from Form 861 (US DOE/EIA, 2001g). 
Table 4. Federal and California State Data Sources Used to Calculate Average Emissions Factors

\begin{tabular}{|c|c|c|}
\hline $\begin{array}{l}\text { Agency and } \\
\text { Form Number }\end{array}$ & Name of Data Source and Data Description & $\begin{array}{l}\text { Years Data } \\
\text { Available }\end{array}$ \\
\hline EIA Form 412 & $\begin{array}{l}\text { Annual Report of Public Electric Utilities } \\
\text { income statements, balance sheets, sales and purchases, } \\
\text { and transmission line data }\end{array}$ & $1990-2000$ \\
\hline EIA Form 759 & $\begin{array}{l}\text { Monthly Power Plant Report } \\
\text { net generation, fuel consumption, fuel stocks, prime } \\
\text { mover and fuel type }\end{array}$ & $1990-2000$ \\
\hline EIA Form 767 & $\begin{array}{l}\text { Steam-Electric Plant Operation and Design Report } \\
\text { plant operations and equipment design as well as data on } \\
\mathrm{SO}_{2}, \mathrm{NO}_{\mathrm{x}} \text {, and } \mathrm{CO}_{2} \text { emissions }\end{array}$ & $1996-2000$ \\
\hline EIA Form 860B & $\begin{array}{l}\text { Annual Electric Generator Report - Nonutility } \\
\text { facility nameplate capacity, unit type, prime mover, } \\
\text { energy source, fuel consumption, heat content, facility } \\
\text { generation, purchases, sales to utility, facility use, and } \\
\text { on-line date }\end{array}$ & $1998-1999$ \\
\hline EIA Form 861 & $\begin{array}{l}\text { Annual Electric Utility Report } \\
\text { peak load, generation, electric purchases, sales, and } \\
\text { revenues }\end{array}$ & $1990-2000$ \\
\hline EIA Form 900 & $\begin{array}{l}\text { Monthly Nonutility Power Plant Report } \\
\text { net generation, fuel consumption, prime mover, and fuel } \\
\text { type }\end{array}$ & $1999-2000$ \\
\hline EIA & $\begin{array}{l}\text { Wholesale Electric Trade Database } \\
\text { power purchases, sales for resale, wheeling, and } \\
\text { transmission data by utility }\end{array}$ & $1991-1995$ \\
\hline FERC Form 423 & $\begin{array}{l}\text { Monthly Report of Cost and Quality of Fuels for } \\
\text { Electric Plants } \\
\text { fuel type, fuel origin, fuel quantity, and fuel quality }\end{array}$ & $1990-2000$ \\
\hline FERC Form 714 & $\begin{array}{l}\text { Annual Electric Control and Planning Area Report } \\
\text { hourly load data, generation data, and hours connected } \\
\text { to load }\end{array}$ & $1993-2000$ \\
\hline $\mathrm{CEC}^{\mathrm{a}}$ & $\begin{array}{l}\text { Power Source Disclosure } \\
\text { plant and retailer-level data on energy traded under } \\
\text { specific purchases - may include green energy products } \\
\text { as well as energy sold by municipal power agencies }\end{array}$ & $1998-2000$ \\
\hline CEC & $\begin{array}{l}\text { California Electricity Generation } \\
\text { annual fuel specific generation by fuel type and net } \\
\text { imports }\end{array}$ & $1983-2000$ \\
\hline $\mathrm{CAISO}^{\mathrm{b}}$ & $\begin{array}{l}\text { power flow data } \\
\text { Hourly loads and monthly net imports from outside the } \\
\text { CAISO area for the three CAISO controlled utility } \\
\text { areas. }\end{array}$ & $1999-2000$ \\
\hline
\end{tabular}




\section{Non-Utility Data}

Data for non-utility generators were taken from two sources: annual data provided in Form 860B (US DOE/EIA, 2001h) and monthly data from Form 900 (US DOE/EIA, 2001i). Since non-utility generators frequently use some or most of the power generated on-site, all of the emissions from fuel consumption cannot be allocated to the grid. Form 860B provides considerable detail on non-utility operations, reporting not only the total electricity generated but also the amount used on-site and the amount delivered to the grid. (Direct sales to end-users are also reported, but these figures are not explicitly provided in the $860 \mathrm{~B}$ datasets.) Additionally, CHP units provide information on their useful thermal output.

There was some confusion in the 1999 reports over whether sales to resellers should be counted as sales to utilities or sales to end-users. Thus, some large stations reported very little power being sold to utilities although nearly all of their output was sold to an affiliated reseller. Since this sales information is confidential, it is not possible to know with any certainty how much of this power was sold under direct contracts and how much was sold to CAISO or in the CalPX markets. For example, three of California's larger non-utility generating stations, Moss Landing, Morro Bay, and Pittsburg, report little or no power delivered to utilities on Form 860B. These stations are among the larger gasfired stations in the state and are large enough to significantly affect the results. Given the amount of power generated at these stations, it is not likely that sales under direct contract account for a large share of their output. For this study, it was assumed that all of the power reported as sold to end users was actually delivered to the general power pool.

Another problem with the non-utility data is that Form 900 does not include data on plants of less than $50 \mathrm{MW}$ capacity. In California alone, there are over 300 such gridconnected plants, which in 1999 delivered over $21 \mathrm{TWh}$ to the grid (about a quarter of all non-utility generation to the grid). ${ }^{26}$ Since the monthly calculations are based on data from Form 900, this led to large inconsistencies at the statewide level and particularly for the PCAs with large shares of non-utility generation: PG\&E and SCE. In order to correct for this, the total annual net generation and emissions for all plants less than $50 \mathrm{MW}$ were tallied both for the state and each California PCA. We assumed that these small plants, on average, operated at relatively consistent capacity factors throughout the year and consequently divided the total emissions and generation by 12 and created a dummy plant for each PCA with this average monthly generation and emissions. A handful of plants with a capacity of less than $50 \mathrm{MW}$ did report on Form 900, but the resulting doublecounting does not significantly affect the results.

Prior to 1998, non-utility data were regarded as confidential. Thus, there are no 1990 data on non-utility generators available from the EIA. For this reason, 1990 AEFs were not calculated using the PDS method.

${ }^{26}$ Calculated from EIA Form 860B: US DOE/EIA, 2001h 


\section{System Loads and Net Imports}

System load data for the CAISO-controlled utility areas were taken from the CAISO website (CAISO, 2001), while load data for LADWP were taken from the FERC Form 714 (FERC, 2001). The net imports needed for each system to meet its load were calculated simply as the difference between its load and the sum of generation within the PCA and the output shares of any out-of-state plants owned by the utility.

\section{Specific Purchases: “Green Power" and Power Content Disclosure (SB 1305)}

With the opening of the California electricity market to retail competition in 1998, electricity retailers were able to offer "green power" products to customers. Retailers distinguish these products from the general pool power based on the energy sources used to generate the power. Senate Bill 1305 established a system for estimating the shares of energy sources used to generate both green power products and the average for the state power pool (California State Senate, 1997). This system tracks retailers' specific purchases of electricity by plant for use in their green power products and subtracts these purchases from the net system power used by average customers in the state. Specific purchases of power for use in a green power product are defined as "[auditable] electricity transactions which are traceable to specific generation sources." In 1999, specific purchases did not play a large role in total state power sales, totaling approximately $6.5 \mathrm{TWh}$ of power sold.

\section{METHODOLOGY}

\section{Fuel Conversion Factors: Coal}

The EIA data on fuel consumption by electricity generators are given in physical quantities, such as tons of coal or cubic feet of natural gas. The conversion of these data from mass of fuel to mass of $\mathrm{CO}_{2}$ released requires a two-step transformation of the physical data, first into heat content consumed and then into $\mathrm{CO}_{2}$ released. This is due to the fact that fuel quality varies, with coal or oil from some sources having higher shares of moisture and noncombustible material.

This variation in fuel quality is particularly important for coal, which varies substantially both among grades (e.g., anthracite, bituminous, lignite) and within grades, from one region to another. Since the amount of $\mathrm{CO}_{2}$ released depends heavily on the heat content, the $\mathrm{CO}_{2}$ per unit mass of coal can show large differences. The EIA provides a national utility average coal heat content in the Annual Energy Review (AER) (US DOE/EIA 2001c). The figure provided in the AER 2000 lists $23.73 \mathrm{MJ} / \mathrm{kg}$ as the average for 1999, but this national average hides the disparities in coal quality among the coal producing regions.

State specific coal heat content factors are provided in the State Energy Data Report (SEDR) (US DOE/EIA 2001a). These factors aggregate both bituminous grades of coal and lignite into one factor, but this does not affect plants located in the Western Systems 
Coordinating Council (WSCC) since no lignite is used in this region. In order to cross check the factors in SEDR, data reported in the 1999 FERC Form 423 were also used to derive a separate factor for bituminous grades. State coal factors were derived from Form 423 by taking the consumption-weighted average of the coal quality data for bituminous and sub-bituminous grades of coal reported by each plant. These figures are compared in Table 5 below. Since negligible amounts of coal are consumed in both California and Idaho, no state coal factors are provided for these states. Given the small differences between the two sets of factors, the SEDR figures were used since they come from a public source and will be updated on an annual basis.

Table 5: 1999 Coal Heat Content Factors for States in the Western Systems Coordinating Council, $\mathrm{MJ} / \mathrm{kg}$

\begin{tabular}{l|c|c|c|c|c|c|c|c|c}
\hline & AZ & CO & MT & NV & NM & OR & UT & WA & WY \\
\hline FERC 423 $^{\text {a }}$ & 23.83 & 22.92 & 19.86 & 27.09 & 21.39 & 20.72 & 27.30 & 19.63 & 20.04 \\
SEDR 1999 $^{\mathrm{b}}$ & 23.85 & 22.68 & 19.62 & 26.18 & 21.24 & 20.84 & 27.03 & 19.13 & 20.43 \\
\hline
\end{tabular}

a Weighted average of all bituminous and sub-bituminous coal consumed by utilities as reported in the 1999 FERC Form 423.

b Adapted from Table C13 in the State Energy Data Report 1999 (US DOE/EIA 2001a). These are the weighted average of bituminous coal and lignite. http://eia.doe.gov/pub/state.data/pdf/pend-c.pdf

Differences in the $\mathrm{CO}_{2}$ emitted per mass of coal burned depend much more on differences in the heat contents per mass than the carbon per heat ratio. Table 6 lists the $\mathrm{CO}_{2}$ emissions factors from SEDR 1999. The difference between the highest and lowest figures is about 2 percent - much less than the difference between the heat contents, which is about 40 percent. Given the small degree of variation in the coal factors, the national coal electric factor of $24.42 \mathrm{kgC} / \mathrm{GJ}$ from the EIA's Emissions of Greenhouse Gases in the United States 1999 (US DOE/EIA 2000A) was used.

Table 6. $1999 \mathrm{CO}_{2}$ Emissions Factors of Coal Consumed by Electric Utilities, $\operatorname{kgC} / \mathbf{G J}^{27}$

\begin{tabular}{l|l|l|l|l|l|l|l|l|l}
\hline & AZ & CO & MT & NV & NM & OR & UT & WA & WY \\
\hline SEDR 1999 & 24.12 & 24.01 & 24.18 & 24.05 & 24.16 & 23.69 & 23.70 & 24.16 & 24.14 \\
\hline a & $\begin{array}{l}\text { Adapted from Table F4 in the State Energy } \\
\text { http://eia.doe.gov/pub/state.data/pdf/pend-f.pdf }\end{array}$
\end{tabular}

\section{Fuel Conversion Factors: Other Fuels}

For most other fuels, both the heat content factors and carbon coefficients were adapted from EIA's Emissions of Greenhouse Gases in the United States 1999 (U.S. DOE/EIA 2000A). However, the EIA Form 860B lists plant-specific heat factors for each fuel so these values were used for the non-utility generators. The EIA does not provide carbon coefficients for all of the numerous fuel types used by non-utilities. Therefore, some fuels from the EIA Form 860B were assigned the carbon coefficients of similar fuels:

\footnotetext{
${ }^{27}$ The carbon factors shown may be divided by 100 for a back-of-the-envelope approximation of the fuelspecific emissions factor for coal with an assumed heat rate of $10 \mathrm{MJ} / \mathrm{kWh}$.
} 
petroleum consumption was converted to carbon using the carbon factor for residual fuel oil, "other gas" was assumed to be refinery gas ${ }^{28}$, and diesel was converted using the factor for distillate fuel oil. Since the EIA report does not provide carbon coefficients for propane gas or refinery gas, those coefficients were adapted from the IPCC (IPCC, 1996). Other fuels were either assumed to produce zero net emissions (e.g. agricultural byproducts, municipal waste, and wood waste) or were ignored due to the small shares of electricity generated from them (e.g. butane, bituminous gob). The conversion factors and their sources are summarized in Table 7.

\section{Table 7. 1999 Heat and Carbon Conversion Factors and Sources}

\begin{tabular}{|c|c|c|c|c|c|c|}
\hline $\begin{array}{l}\text { EIA } \\
\text { Fuel } \\
\text { Code }\end{array}$ & Fuel Name & $\begin{array}{c}\text { GJ per } \\
\text { Physical } \\
\text { Unit }\end{array}$ & $\begin{array}{c}\text { Physical } \\
\text { Unit }\end{array}$ & Source & $\mathrm{kgC/GJ}$ & Source \\
\hline FO2 & Distillate Fuel Oil & 0.0516 & liter & AER 2000 & 18.91 & U.S. DOE/EIA 2000a \\
\hline FO6 & Residual Fuel Oil & 0.0557 & liter & AER 2000 & 20.18 & U.S. DOE/EIA 2000a \\
\hline $\mathrm{PC}$ & Petroleum Coke & 0.0533 & liter & AER 2000 & 26.40 & U.S. DOE/EIA 2000a \\
\hline BIT & Bituminous Coal & Varies & Metric ton & SEDR 1999 & 24.42 & U.S. DOE/EIA 2000a \\
\hline LIG & Lignite & 15.12 & Metric ton & AER 2000 & 25.67 & $\begin{array}{l}\text { Adapted from IPCC, } \\
1996\end{array}$ \\
\hline NG & Natural Gas & 38.37 & $1000 \mathrm{~m} 3$ & AER 2000 & 13.71 & U.S. DOE/EIA 2000a \\
\hline OG & Other Gas & Varies & $1000 \mathrm{~m} 3$ & $860 \mathrm{~B}$ & 17.25 & $\begin{array}{l}\text { Adapted from IPCC, } \\
1996\end{array}$ \\
\hline
\end{tabular}

\section{Non-Utility Self-Generation and Cogeneration}

Assigning emissions from non-utility sources is considerably more complicated than for utility sources. Utility-owned generators use a limited set of fuels (coal and natural gas account for the bulk of thermal generation), and the emissions from all of these fuels can be assigned to pool power of the grid. This is because utilities generally do not enter into direct contracts with end-users that specify electricity from particular stations. Non-utility generators, however, use a much greater variety of fuels, they may use some or most of the power generated for on-site consumption, some are cogenerating stations that produce process heat in addition to electricity, and some stations sell most of their power to resellers, who may sell some power directly to end users and some to the general pool.

One analytical challenge is that non-utility generators are frequently not dedicated providers to the grid; much of the power produced may be used on-site or sold directly to other end users. However, the EIA forms report total fuel consumption. To correct for this, the emissions from fuel combustion were allocated to the grid by the ratio of net electricity delivered to the grid to total generation (i.e., $\mathrm{E}_{n} / \mathrm{E}_{t}$ ). Since the monthly Form 900 permits generators to report either gross or net generation, the $\mathrm{E}_{n} / \mathrm{E}_{t}$ ratio was also used to correct electricity output for plants reporting gross generation.

\footnotetext{
${ }^{28}$ Six of the eight facilities listed as using "other gas" in 1999 are associated with refineries.
} 
Another complication is that many non-utility generators are cogenerators, and for these facilities, the total amount of fuel consumed must be corrected not only for on-site electricity consumption and deliveries to end users, but also for the useful heat produced. With the large number of CHP units in California, this is no trivial concern. Of the 433 non-utility owned stations in California in the 1999 860B, 118 report both delivery of some electricity to utilities and the production of useful thermal output. These stations delivered more than $27 \mathrm{TWh}$ of electricity to the grid. Assigning the emissions of total fuel consumption would overestimate the $\mathrm{CO}_{2}$ emissions arising from final consumers' energy use, but there is no universally accepted standard of allocating fuel consumption to the heat and electricity outputs.

Phylipsen, Blok, and Worrell (1998) provide an overview of six methods that have been used to split CHP fuel consumption. Method 1 is to simply split the fuel on the basis of the ratios of energy output. The electricity output is converted to its thermal equivalent and the fuel allocated would be the ratio of electricity generated to the sum of electricity and useful thermal output. Method 2 uses the same approach but reduces the fuel allocation to heat output since it is a lower quality energy source. The ratio used in Method 3 splits the fuels based on the economic value of heat and steam. Method 4 allocates all of the energy saved energy to the electricity generation, while Method 5 allocates the savings to heat production. Method 6 shares the savings between heat and electricity.

The approach used here was a variation of Method 4. The useful thermal energy was divided by $\eta=0.95$ to represent the conversion of fuel heat content to useful energy at high efficiency. This is a somewhat arbitrary value and alternatives could be considered, if more specific information were available. The rest of the heat content in the fuel was allocated to electricity generation, and this was corrected for share of electricity delivered to the grid. This relationship is shown below in Equation 1 where

$\mathrm{F}_{\mathrm{en}}=$ heat content of fuel allocated to net (grid) electricity production (joules)

$\mathrm{E}_{\mathrm{n}}=$ net electricity delivered to the grid $(\mathrm{kWh})$

$\mathrm{E}_{\mathrm{t}}=$ total electricity generation $(\mathrm{kWh})$

$\mathrm{F}_{\mathrm{t}}=$ heat content of total fuel input (joules)

$\mathrm{H}=$ useful heat output (joules)

$\eta=$ efficiency of energy conversion for heat $(\%)$.

\section{Equation 1. Allocation of CHP Fuel Input to Grid Delivered Electricity}

$$
F e n=\frac{E n}{E t} \times\left(F t-\frac{H}{\eta}\right)
$$

\section{Accounting for Out-of-State Plants Partially Owned by California Utilities}

One complication in the case of California is that several CA utilities own some generation resources outside the state. Table 8 lists the plants in other WSCC states with some share of California utility ownership. By CEC convention, these plants (or shares of plants) are considered in-state plants for purposes of determining annual gross system 
power sources and net imports. This convention has a large effect on the generation and emissions for the state and particularly for LADWP and SCE. LADWP also has a contractual arrangement with the other member utilities of the Intermountain Power Agency to buy the excess power they do not need. In 1999, LADWP's actual share of generation from Intermountain was 62.785\% (Tharp 2002). Assuming that California utilities take power from these plants before importing power from other sources, the generation and emissions from their shares of the output from these plants were assigned to their PCAs before meeting the load with other imports.

Table 8. CA Utility Ownership Shares of Out-of-State Plants

\begin{tabular}{l|c|c|r|c|c|c|c|c}
\hline Plant & State & $\begin{array}{c}\text { Primary } \\
\text { Fuel }\end{array}$ & $\begin{array}{c}\text { Capacity, } \\
\text { MW }\end{array}$ & SCE & LADWP & Other & IID $^{\mathbf{a}}$ & CDWR $^{\mathbf{b}}$ \\
\hline Four Corners & NM & Coal & 2,270 & $35 \%$ & $0 \%$ & $0 \%$ & $0 \%$ & $0 \%$ \\
Intermountain & UT & Coal & 1,640 & $0 \%$ & $45 \%$ & $30 \%$ & $0 \%$ & $0 \%$ \\
Mohave & NV & Coal & 1,636 & $56 \%$ & $20 \%$ & $0 \%$ & $0 \%$ & $0 \%$ \\
Navajo & AZ & Coal & 2,409 & $0 \%$ & $21 \%$ & $0 \%$ & $0 \%$ & $0 \%$ \\
Palo Verde & AZ & Nuclear & 4,210 & $16 \%$ & $6 \%$ & $6 \%$ & $0 \%$ & $0 \%$ \\
Reid Gardner & NV & Coal & 612 & $0 \%$ & $0 \%$ & $0 \%$ & $0 \%$ & $30 \%$ \\
San Juan & NM & Coal & 1,779 & $0 \%$ & $0 \%$ & $0 \%$ & $6 \%$ & $0 \%$ \\
Yucca & AZ & Gas & 279 & $0 \%$ & $0 \%$ & $0 \%$ & $31 \%$ & $0 \%$ \\
\hline
\end{tabular}

${ }^{a}$ Imperial Irrigation District

${ }^{\mathrm{b}}$ California Department of Water and Resources

Sources: U.S. EPA (2001c) and Intermountain Power Agency (2002)

\section{Estimating Imports and Associated $\mathrm{CO}_{2}$ Emissions}

Once the in-state and PCA generation and emissions have been determined, emissions and generation from imports need to be calculated. Net imports were determined by first summing monthly and annual loads from hourly load data for each of the four major PCAs. Then, the intra-PCA generation and output shares from the utilities' out-of-state plants were subtracted from the load totals. Finally, an emissions factor was applied to the imported electricity and the resulting emissions added to the total from within each PCA.

Since the power entering the state must cross the transmission lines at either the California-Oregon border or the southeastern portion of the state, the WSCC was divided into two regions, the Southwest (Arizona, Nevada, New Mexico, Utah, and Colorado) and the Northwest (Idaho, Washington, Oregon, Montana, and Wyoming). For each of these two regions, the total generation and emissions were calculated from the EIA annual Forms 759 and 860B, using the fuel heat and carbon conversion factors described above. Imports were assumed to be representative of the average fuel mix of their region. The regional AEFs shown in Table 9 were multiplied by the quantities of electricity imported to estimate the $\mathrm{CO}_{2}$ emissions due to Californians' consumption of this electricity. As a simplifying assumption, imports into PG\&E were assumed to come from the Northwest, while imports into the other PCAs were assumed to originate in the Southwest. 
Table 9. 1999 Electricity Generation, Electricity-Related $\mathrm{CO}_{2}$ Emissions and AEFs for the WSCC Regions.

\begin{tabular}{r|c|c|c|c|c|c}
\hline & \multicolumn{2}{|c|}{ Annual $^{\mathrm{a}}$} & \multicolumn{2}{c|}{ May } & \multicolumn{2}{c}{ October } \\
\cline { 2 - 7 } & Southwest $^{\mathrm{a}}$ & Northwest & Southwest & Northwest & Southwest & Northwest \\
\hline $\begin{array}{r}\text { Generation } \\
(\mathrm{TWh})\end{array}$ & 184.1 & 247.4 & 14.7 & 19.2 & 15.3 & 16.3 \\
$\mathrm{CO} 2$ Emissions & 36.0 & 17.7 & 2.8 & 1.2 & 3.1 & 1.5 \\
$\begin{array}{r}(\mathrm{MtC}) \\
\text { Emissions }\end{array}$ & 0.196 & 0.072 & 0.187 & 0.063 & 0.203 & 0.095 \\
$\begin{array}{r}\text { Factor } \\
(\mathrm{kgC} / \mathrm{kWh})\end{array}$ & & & & & & \\
\hline
\end{tabular}

${ }^{\mathrm{a}}$ California utilities shares of emissions and generation have been deducted from the Southwest totals.

\section{Accounting for Specific Purchases}

In order to improve the accuracy of the emissions factors, emissions from the net system power should be estimated for each PCA as well as the entire state. Customers subscribed to a green power product will calculate their actual or avoided emissions estimates based on documentation pertaining to the sources of their product. Separating green power from the net system power avoids double counting of the emissions and generations of the specific purchases for green power products. Using data provided by the CEC, net sales of power for specific purchases were identified by plant. Matching these plants to EIA generation data, the shares of specific purchase sales were calculated as a percentage of total net generation. Then the specific purchases as well as the corresponding shares of each plant's emissions were removed from the grid power calculations.

Analysis of the specific purchase data furnished by CEC reveals that for 1999, the amount of generation diverted into green power products amounted to less than three percent of the total state load. Although excluding specific purchases does not significantly affect AEFs for the state or any particular PCA, this was done to test the method for possible future use. Total specific purchases were a little over 6.5 TWh (CEC 2001d). About a third of the power used for specific purchases was generated out of state. The 4.5 TWh of specific purchases generated in-state did not have much impact on PCA AEFs since they represented less than three percent of PG\&E's load and well less than one percent in the other PCAs. Since these purchases were such a small share of the total load, the PDS results below remain comparable to those produced by the LDC method in Section V.

\section{PRospects For FUtURE DATA}

One strength of this approach is the reliability of the data sources. EIA will continue to receive and publish information on electricity generation and fuel consumption for the foreseeable future. Data for non-utility generation should continue to improve. Beginning with the 2001 reporting year, there are no longer separate forms for utility and non-utility generators. Forms 759 and 900 have been superseded by Form 906, "Power Plant Report" and Forms 860A and 860B have become Form 860, "Annual Electric Generator Report." With this change the fuel codes and units and will be consistent for utility and 
non-utility sources. Moreover, Form 906 now requires some non-utility units of less than $50 \mathrm{MW}$ to report, but this varies by fuel type.

The key problem that has limited the accuracy of the PDS approach is the tracking of power flows. A better, easier-to-understand source of net flows between PCAs is needed, which would allow analysts to more easily assign responsibility for the emissions. The confidentiality of energy traders' purchases and sales will exacerbate this problem in deregulated markets. While some CEC and EIA data do provide information on annual net imports and other transmission data, monthly data are generally not in the public domain. If CAISO and other system operators were required to furnish monthly aggregates on inter-PCA flows, this would greatly facilitate the estimation of monthly emissions factors.

\section{E. RESULTS}

In order to reveal the importance of California's in-state generation, out-of-state generation, and imports on the statewide AEF, the generation and emissions are decomposed by their sources in Table 10. Due to the large preponderance of hydro, nuclear, and natural gas in the state's resource mix, California emits very little $\mathrm{CO}_{2}$ relative to the amount of generation in the state. As Table 10 shows, less than half of the emissions from Californians' electricity consumption is from generation facilities within the state boundaries. The sizable out-of-state capacity owned by California utilities has a major effect on the state's generating profile. About three-fourths of California's share of the electricity generated by these plants is coal-fired, whereas negligible amounts of coal are burned by in-state generators. It is interesting to note that the AEF for out-of-state plants closely matches that of general Southwest imports. The California out-of-state generation has a slightly higher share of coal-fired generation, but the rest is nuclear. This offsets the shares of natural gas and hydro embedded in the Southwest averages. Thus, for the state as a whole, whether these emissions are accounted for separately or aggregated with other Southwest emissions will not substantially alter the estimates of indirect emissions outside of California. The final column in Table 10 sums the generation and emissions from all sources and provides the resulting weighted AEF of $0.106 \mathrm{kgC} / \mathrm{kWh}$.

Table 10. 1999 California Electricity Generation, CO2 Emissions, and AEFs by Source

\begin{tabular}{r|c|c|c|c|c|c}
\hline & $\begin{array}{c}\text { In- } \\
\text { State }\end{array}$ & $\begin{array}{c}\text { Out-of- } \\
\text { State }\end{array}$ & $\begin{array}{c}\text { In-State }+ \\
\text { Out-of-State }\end{array}$ & $\begin{array}{c}\text { SW } \\
\text { Imports }\end{array}$ & $\begin{array}{c}\text { NW } \\
\text { Imports }\end{array}$ & Total CA \\
\hline Generation $(\mathrm{TWh})$ & 170.14 & 37.16 & 207.30 & 41.87 & 19.77 & 268.94 \\
CO2 Emissions & 11.92 & 7.36 & 19.28 & 8.16 & 1.41 & 28.86 \\
$(\mathrm{MtC})$ & & & & & & \\
$\mathrm{AEF}(\mathrm{kgC} / \mathrm{kWh})$ & 0.070 & 0.198 & 0.093 & 0.194 & 0.071 & 0.107 \\
\hline
\end{tabular}

Table 11 shows the same breakdown in generation and emissions, disaggregated by PCA. Together these PCAs capture the greater part of all electricity production in the state, 
accounting for almost 95\% of all generation. Additionally, LADWP and SCE account for more than three-fourths of out-of-state generation owned by California utilities. Since PG\&E and SDG\&E do not own generating resources out of state, this category is not shown for these utilities.

Table 11. 1999 Electricity Generation, CO2 Emissions and AEFs by Power Control Area

\begin{tabular}{|c|c|c|c|c|c|c|c|c|c|c|}
\hline \multirow[t]{2}{*}{ Utility } & \multicolumn{2}{|c|}{ PG\&E } & \multicolumn{3}{|c|}{ SCE } & \multicolumn{2}{|c|}{ SDG\&E } & \multicolumn{3}{|c|}{ LADWP } \\
\hline & In-State & $\begin{array}{c}\text { Total, } \\
\text { w/ } \\
\text { Imports }\end{array}$ & In-State & $\begin{array}{c}\text { In-State } \\
+ \text { Out- } \\
\text { of-State }\end{array}$ & $\begin{array}{c}\text { Total, } \\
\text { w/ } \\
\text { Imports }\end{array}$ & In-State & $\begin{array}{c}\text { Total, } \\
\text { w/ } \\
\text { Imports }\end{array}$ & In-State & $\begin{array}{c}\text { In-State } \\
+ \text { Out- } \\
\text { of-State }\end{array}$ & $\begin{array}{c}\text { Total, } \\
\text { w/ } \\
\text { Imports }\end{array}$ \\
\hline Generation (TWh) & 90.64 & 110.41 & 52.22 & 67.72 & 98.06 & 11.41 & 18.82 & 6.48 & 20.95 & 25.07 \\
\hline $\begin{array}{r}\mathrm{CO}_{2} \text { Emissions } \\
(\mathrm{MtC})\end{array}$ & 5.62 & 7.04 & 4.12 & 7.00 & 12.92 & 1.20 & 2.64 & 0.89 & 4.02 & 4.82 \\
\hline $\mathrm{AEF}(\mathrm{kgC} / \mathrm{kWh})$ & 0.062 & 0.064 & 0.079 & 0.103 & 0.132 & 0.105 & 0.140 & 0.138 & 0.192 & 0.192 \\
\hline
\end{tabular}

For the calculations in Table 11, the shares of generation and emissions from in-state and CA-owned out-of-state plants were assumed to be the first sources to meet each PCA's load. Then net inflow data from CAISO (for the CAISO PCAs) and the EIA Form 861 (for LADWP) were used to meet the remaining load deficit. The results demonstrate that significant differences in the amount of $\mathrm{CO}_{2}$ released per $\mathrm{kWh}$ consumed exist among California's PCAs even when out-of-state resources are not considered. This is due to the fact that nuclear, hydro, and other zero-emission energy sources provide a much greater share of some utilities' power. Figure 1 depicts the fuel breakdown of each PCA's generating resources by 1999 production. For LADWP and SCE this is shown both for in-state plants only and for the in-state plants with the shares of out-of-state plants. Large shares of nuclear, hydro, and renewables hold down emissions in the PG\&E and SCE areas, while SDG\&E and LADWP depend more heavily on natural gas. These differences are exacerbated by the shares of coal-fired plants owned by LADWP and SCE. The variation in the AEFs shown in Table 11 suggests that accounting for differences among the PCAs will be important to accurately estimate end-users' $\mathrm{CO}_{2}$ emissions. 


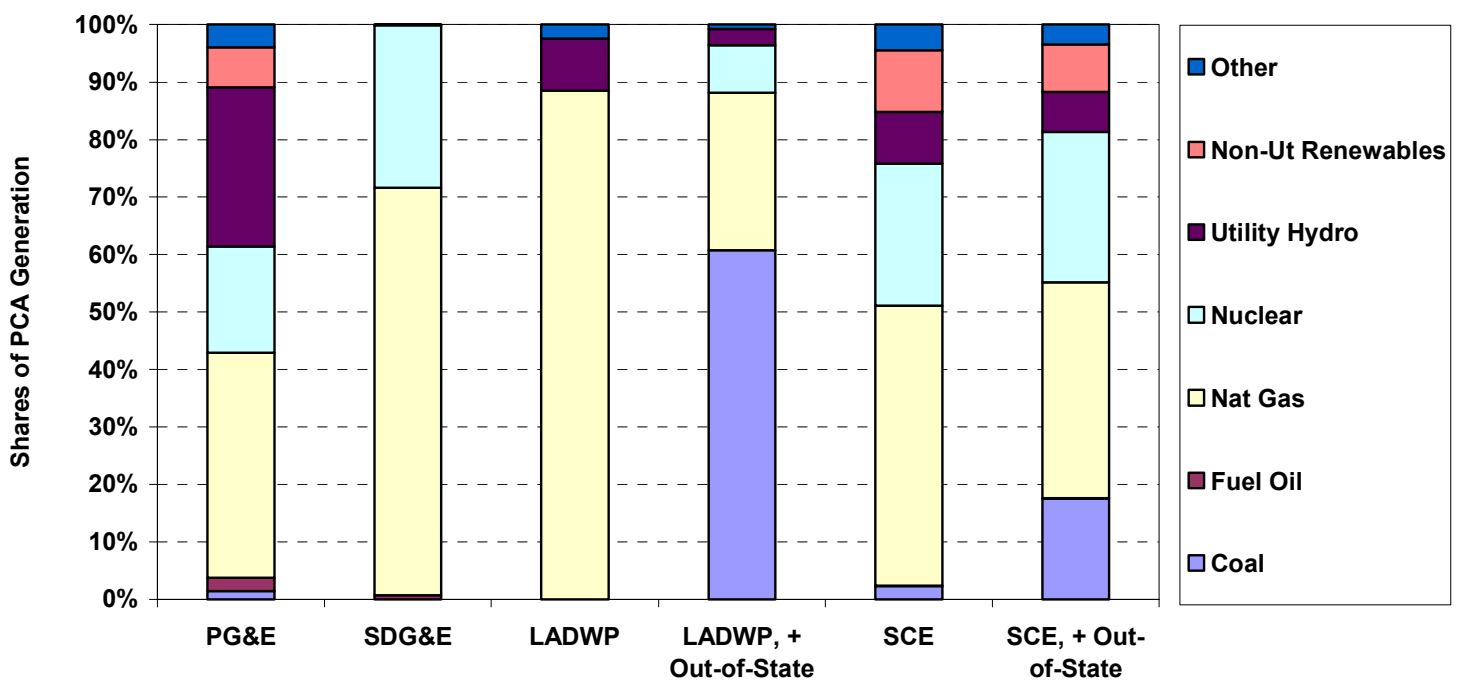

Figure 1. Electricity Generation Fuel Shares by PCA, without Imports

In addition to examining the differences in the AEFs among PCAs, Berkeley Lab also used monthly data to explore the effect of seasonal variation in precipitation and snowmelt on PCA and statewide AEFs. To do this, May and October were selected as representative months since they are months with relatively high and low levels of hydro generation, respectively. The AEFs from in-state, in-state plus out-of-state, and total generation and emissions are shown in Table 12. The final column in Table 12 reports the percent difference in total AEFs. PG\&E, the most hydro dependent PCA, has by far the largest variation between the two months. This occurs both because more gas-fired generation is used within PG\&E to compensate for declining hydro production and more electricity is imported from the Northwest. In other months, the power from the Northwest would have a very low AEF, but the fall in hydro generation also affects this region, where more coal-fired electricity is used to replace the loss of hydroelectricity (Table 9).

Table 12. 1999 PCA and Statewide Emissions Factors In-State And With Imports, May \& October

\begin{tabular}{|c|c|c|c|c|c|c|c|}
\hline \multirow[t]{2}{*}{ Utility } & \multicolumn{3}{|c|}{ May } & \multicolumn{3}{|c|}{ October } & \multirow{2}{*}{$\begin{array}{c}\text { Percent } \\
\text { Difference } \\
\text { Oct/May }\end{array}$} \\
\hline & $\begin{array}{c}\text { In-State } \\
\text { Only }\end{array}$ & $\begin{array}{c}\text { In-State }+ \\
\text { Out-of-State }\end{array}$ & $\begin{array}{l}\text { Total, w/ } \\
\text { Imports }\end{array}$ & $\begin{array}{c}\text { In-State } \\
\text { Only }\end{array}$ & \begin{tabular}{|c|} 
In-State + \\
Out-of-State
\end{tabular} & $\begin{array}{l}\text { Total, w/ } \\
\text { Imports }\end{array}$ & \\
\hline PG\&E & 0.043 & 0.043 & 0.046 & 0.079 & 0.079 & 0.083 & $79 \%$ \\
\hline SCE & 0.058 & 0.083 & 0.122 & 0.084 & 0.105 & 0.132 & $8 \%$ \\
\hline SDG\&E & 0.096 & 0.096 & 0.150 & 0.089 & 0.089 & 0.134 & $-11 \%$ \\
\hline LADWP & 0.144 & 0.194 & 0.192 & 0.143 & 0.184 & 0.184 & $-5 \%$ \\
\hline $\mathbf{C A}^{\mathbf{a}}$ & 0.053 & 0.074 & 0.098 & 0.086 & 0.103 & 0.117 & $19 \%$ \\
\hline
\end{tabular}

${ }^{a}$ Includes only the four PCAs shown in Table 12.

For the other utility areas, the seasonal difference is much less pronounced. However, the impact of the hydro cycle on PG\&E's emissions has an appreciable effect on the statewide average, which jumps 19\% overall. 
In all, these findings point to two clear conclusions. First, the regional power systems in California are supplied by very different resource mixes. These differences are too large to be ignored, as each $\mathrm{kWh}$ of electricity used in Los Angeles may release nearly three times as much $\mathrm{CO}_{2}$ as a $\mathrm{kWh}$ used in San Jose. Accurate estimation of indirect $\mathrm{CO}_{2}$ releases by Registry participants must consider these regional differences. Second, variation in the hydro cycle leads to significant changes in the AEF of California electricity - particularly for PG\&E. This may not matter for participants whose electricity consumption remains stable over the year, but in cases where consumption fluctuates (e.g. higher use to cool offices in summer) one annual emissions factor may also result in substantial inaccuracies. 


\section{CALCULATING ELECTRICITY EMISSION FACTORS FOR THE EARLY 1990S: ELFIN SIMULATION}

The Elfin model was used to simulate plant operations and estimate emissions for 1990. This model was a widely used forecasting tool for California utility power systems during the 1980s and early 1990s, roughly until publication of the last biennial CEC Electricity Report for 1996. Fortunately, old data sets that were compiled and publicly scrutinized during this period are still available in the public domain and can be used to replicate historic conditions. Data sets for six electricity utility service territories were provided by CEC and all were run for 1990. Elfin has its own built-in plant and contract data for modeling emissions from cogeneration and imports. This model provides a great deal of versatility for determining emissions factors. In addition to providing annual AEFs and MEFs for the state and each PCA, it can also estimate emissions factors on a monthly basis as well as for other sub-periods, such as for on- and off-peak hours (CEC, 1990; CEC, 1993).

\section{A. STRENGTHS AND LIMITATIONS OF THE ELFIN APPROACH}

Elfin is an electricity production cost and capacity expansion model that was developed over many years by Environmental Defense. Elfin, like many electricity production simulation models uses an approach based on the same load duration curve principles described in section V.A. Many models use the LDC framework but modify it with sophisticated mathematics to produce more accurate results. One important piece of mathematics used by Elfin and most load duration curve models is convolution that is used to represent the effect of uncertain plant failures on outcomes. In addition to convolution, the use of multiple LDCs for time variation is probably an important enhancement over simple LDC models. Elfin not only simulates system operations year by year, but it can develop an expansion plan for the system. This can be done using the Iterative Cost Effectiveness Method model (ICEM) and/or the Iterative Test of Resource Effectiveness (ITRE). These two algorithms were quasi-official California methods before electric industry restructuring. Use of Elfin was widespread among California utilities in the 1980s because passage of AB-475 in 1975 required public access and consistency of models used in public proceedings. Since Elfin was widely used in regulatory arenas, it slowly became a de facto standard. Most of California's UDCs and the larger municipal utilities were required to submit Elfin input files during the Biennial Resource Plan Update (BRPU) proceeding, which followed the same cycle as the CEC's Electricity Reports.

The Elfin files provide a rich vein of information that can be used to address the task of establishing electricity emissions factors for the early 1990s. However, Environmental Defense no longer actively supports Elfin, and the files would have to be updated to work on more recent versions of the model. The data sets themselves are not in a conveniently consistent format that makes them easily comparable. Rather, each UDC has adopted its own conventions and formats and learning to interpret any one of the files is a major undertaking. 
The last BRPU covered the 1996 test year, in conjunction with the ER96. After ER96, due to the imminent restructuring of the state's power sector and adverse rulings by FERC on the acceptability of BRPU, the process and the data sets it spawned disappeared. Since the proceedings that led to the ER96 were conducted during 1995, the data in the Elfin input files developed at that time are based on approximately 1994 conditions, although these files were in fact built over a number of years. The ER96 utility files entered the public domain as a result of the BRPU process. Collectively, these files offer a comprehensive source of data covering the California electricity industry, possibly more complete than will ever again be available. These files, therefore, provide a uniquely detailed snapshot of California's power sector, circa 1994. Their value stems not only from their completeness, but also from the fact that the sources for the most part are the utilities themselves, and that these files were carefully reviewed in a lengthy workshop process in which they were subjected to scrutiny by a range of analysts working in the industry.

\section{B. DESCRIPTION OF ELFIN DATA SETS}

In addition to the data provided directly by the utilities, the Elfin files are based on the CEC's Electricity Reports and the ESPAR reports that support them. These provide useful support information such as, utility-specific annual generation by fuel type (CEC, 1990; CEC, 1993; CEC, 1995). Thus, we used ESPAR as our main data source, although 1990 data from EIA were also available. One advantage of using data from EIA forms is that some information is reported monthly, but the drawback is that the definition of various parameters (e.g. sales) and the methods of aggregating generating stations differ from those used in ESPAR. Since adequate information required for resolving the discrepancies between EIA forms and Elfin files is not available, the ESPAR data were used and modified as necessary.

The CEC has Elfin files available for six major California electricity utilities: Southern California Edison (SCE), Pacific Gas \& Electric Company (PG\&E), Los Angeles Department of Water and Power (LADWP), San Diego Gas \& Electric Company (SDG\&E), Sacramento Municipal Utility District (SMUD), and the Imperial Irrigation District (IID). In 1990, the total electrical energy consumed by California end-users, excluding out of state exports and transmissions and distribution (T\&D) losses was 252 TWh (CEC 2001b). The utilities modeled in the Elfin files provide $239 \mathrm{TWh}$ or about $95 \%$, of these requirements (CEC, 1993). Table 13 provides details of the Elfin files for the six utilities.

The base year of the dataset is defined by the user and is, in principle, the year for which each utility's generation and load data were actually compiled. The default simulation year is the first possible forecast year. The load is divided into twelve one-month periods represented by typical weeks and subperiods. These subperiods usually represent weekday and weekend variation as well as time-of-day variation (e.g. sub period "super off peak" represents the time period from 1 am to $4 \mathrm{am}$ ), but the subperiods can be redefined by the user. For the purposes of this study, the default definitions are retained. The capacity to redefine the subperiods enables users to estimate AEFs or MEFs for a variety of scenarios such as on-peak vs. off-peak or weekday vs. weekend. 
Table 13. Elfin Default Simulation and Base Years for California Utilities

\begin{tabular}{l|l|l}
\hline Company & Base Year & $\begin{array}{l}\text { Default } \\
\text { Simulation Year }\end{array}$ \\
\hline Southern California Edison & 1991 & 1996 \\
Pacific Gas \& Electric Company & 1990 & 1996 \\
LA Department of Water and Power & 1991 & 1994 \\
San Diego Gas \& Electric Company & 1991 & 1996 \\
Sacramento Municipal Utility District & 1991 & 1996 \\
Imperial Irrigation District & 1992 & 1994 \\
\hline
\end{tabular}

Source: CEC, 1993.

\section{Modeling ASSUMPTIONS}

Elfin is designed primarily as a forecasting model. Beginning at its base year, it takes annual steps forward through time, simulating each typical week of each month and reporting summaries for the entire year. The goal of this study, however, is not to forecast but to replicate 1990 conditions as closely as possible. Elfin cannot be run for its base year or before, and the base years of the existing files range from 1990 to 1992, as shown in Table 13. Changing the base years of all six UDC files would be a task well beyond the resources available because the base year is pervasive throughout the data sets. Instead, some important 1993 parameters were replaced with actual 1990 data. Essentially, the goal is to trick Elfin to simulate 1990 conditions, by entering data and constraints so that the 1993 model run resembles 1990 as closely as possible. One of the problems with this approach is that while many aspects of the 1993 data can be changed, inevitably many cannot, leaving the possibility for significant inaccuracies.

The validity of our approach was tested by constraining Elfin to hold several important parameters constant at 1993 values and then running Elfin for each of the three following years. The goal was to identify the most important parameters that, when held constant, would produce nearly identical emissions and emissions rates for all years. SCE and PG\&E were chosen as test utilities since they are the two largest. Replacing the total sales and peak loads was critical since these parameters have such a significant impact on Elfin results. To further reduce the variability, fuel prices, and nuclear and hydro generation were also reset to 1993 levels. The simulation runs generated the total emissions and AEFs shown in Table 14. The variability in the emissions factors represents the effect of numerous other parameters that changed during the period 1993 to 1996, e.g., the operating characteristics of some plants may have differed, or some contractual arrangements might have varied. 
Table 14. Variability of AEFs for 1993 data and different run years.

\begin{tabular}{l|c|c|c|c}
\hline Utility & Run Year & $\begin{array}{l}\text { Electricity } \\
\text { (TWh) }\end{array}$ & $\begin{array}{l}\text { Emissions } \\
\text { (MtC) }\end{array}$ & $\begin{array}{l}\text { Emissions } \\
\text { Factor } \\
\text { (kgC/kWh) }\end{array}$ \\
\hline SCE & 1993 & 86.385 & 11.9 & 0.138 \\
& 1994 & 86.385 & 12.1 & 0.140 \\
& 1995 & 86.385 & 11.9 & 0.137 \\
& 1996 & 86.385 & 11.7 & 0.135 \\
\hline PG\&E & 1993 & 88.164 & 7.26 & 0.082 \\
& 1994 & 88.164 & 7.38 & 0.084 \\
& 1995 & 88.164 & 7.35 & 0.083 \\
& 1996 & 88.164 & 7.26 & 0.082 \\
\hline
\end{tabular}

The maximum observed difference in the test emissions factors is about $4 \%$. This suggests that controlling for the factors identified in the test runs, captures most of the variability in results from one year to the next. Therefore, it is assumed that errors in the 1990 results from uncorrected parameters in the input files may be in the same range, although a major discontinuity may have occurred that has not be identified. Note particularly that any forecast year is assumed to have typical plant outages, whereas actual conditions in any year could diverge quite significantly from the expected values, if, for example, a major plant failure occurred. Since the variability in the emissions factors is acceptably low, the approach described was pursued. Below, the steps taken to simulate 1990 are described in more detail.

\section{Eliminate plants installed between 1990 and 1993}

For the actual 1990 simulation, the first step is to reverse any changes in the physical plant capacity that occurred between the target year (1990) and the forecasted year (1993). The capacity additions that took place in California in the period between 1990 and 1993 were identified from EIA data. These plants are few in number and were all combined heat and power (CHP) plants, so the total CHP capacity in 1993 was reduced to match the 1990 capacity.

\section{Input actual 1990 electricity sales by utilities}

Elfin, being primarily a forecasting model, attempts to predict expected (or average) conditions for each year of its forecast. The nature of the problem here differs, however, in that many of the key outcomes of 1990, such as actual sales by UDC, are easily known. Therefore, Elfin was instructed to replicate 1990 sales and peak load. The peak load was estimated from the sales value and the load factor implicit in Elfin input load shapes was maintained.

ESPAR 92 provides data on utility total electricity consumed by California end users, out-of-state exports, and transmission and distribution (T\&D) losses (CEC, 1993). The Elfin files do not include commitments for exports in modeling energy requirements directly, rather exports are modeled in the form of negative sales. To arrive at the energy requirements for 1990, exports are excluded from ESPAR. In other words, an adjustment 
is made so that Elfin models the total ESPAR energy sales correctly. Analysis of the time series data of exports in the Elfin files show that exports remain fairly constant so 1990 exports were assumed to be the same as in other years.

\section{Input actual hydroelectricity production for 1990}

In reality, the actual hourly operation of all the generating plants could be input for 1990 thereby fully constraining the simulation, but these data are not available in the public domain and constraining all plants would be a huge undertaking. Elfin would then no longer be conducting any simulation, and it would most likely not be able to meet all of the imposed constraints. However, it is crucial that the output of the two main carbon-free generating sources, hydro and nuclear, be corrected to 1990 conditions because they have such a dominant effect on emissions results. Note that hydro and nuclear, in addition to being carbon-free and a significant share of the fuel mix for some UDCs, notably PG\&E, vary year-to-year with rainfall, plant outages, and refueling cycles. ESPAR gives utilityspecific annual hydro and nuclear generation for the year 1990 (CEC, 1993) and Elfin's available hydro and nuclear generation were fixed at these 1990 levels as described below.

Figure 2 shows historical hydro generation in California from 1983 to 2000, showing that 1990 was a comparatively dry year. However, Elfin models an average year representing the average hydro conditions in the state. Thus, a downward correction was made to the hydro generation (using ESPAR data) so that Elfin reproduced the actual 1990 hydro generation. The total annual hydro generation in the Elfin files was matched with actual generation (as given in the ESPAR report) by changing the monthly hydro generation specified in the Elfin file by an appropriate value. This value is calculated so the pattern of monthly hydro generation retains that in the original Elfin files. The following steps were taken in making this adjustment:

a) Determined the difference between the annual hydro generation in ESPAR and Elfin. Elfin was run for 1993 to find the monthly and annual hydro generation by utility. This value represents average hydro conditions. Annual generation obtained from the Elfin run was compared with actual 1990 generation as given by ESPAR. The ratio of the two figures was used as a correction factor in the data files.

b) Reduced Elfin default hydro generation to match 1990 actual

Monthly hydro generation is typically segregated separately for different hydro plant categories, most importantly separating pondage and run-of-the-river. Pondage generation is the dispatchable component of the hydro generation while run-of-theriver is a fixed component that must be accepted whenever the generation is available. The default values for these categories were all adjusted down by the ratio described above. By using the same ratio, the monthly generation profiles and plant category shares were maintained. Maintaining the plant categories is critical because they affect the dispatch of thermal generation differently. The annual hydro generation by each utility is simply the sum of monthly generation by all the plant categories. Figure 3 illustrates the corrected monthly generation for PG\&E. 


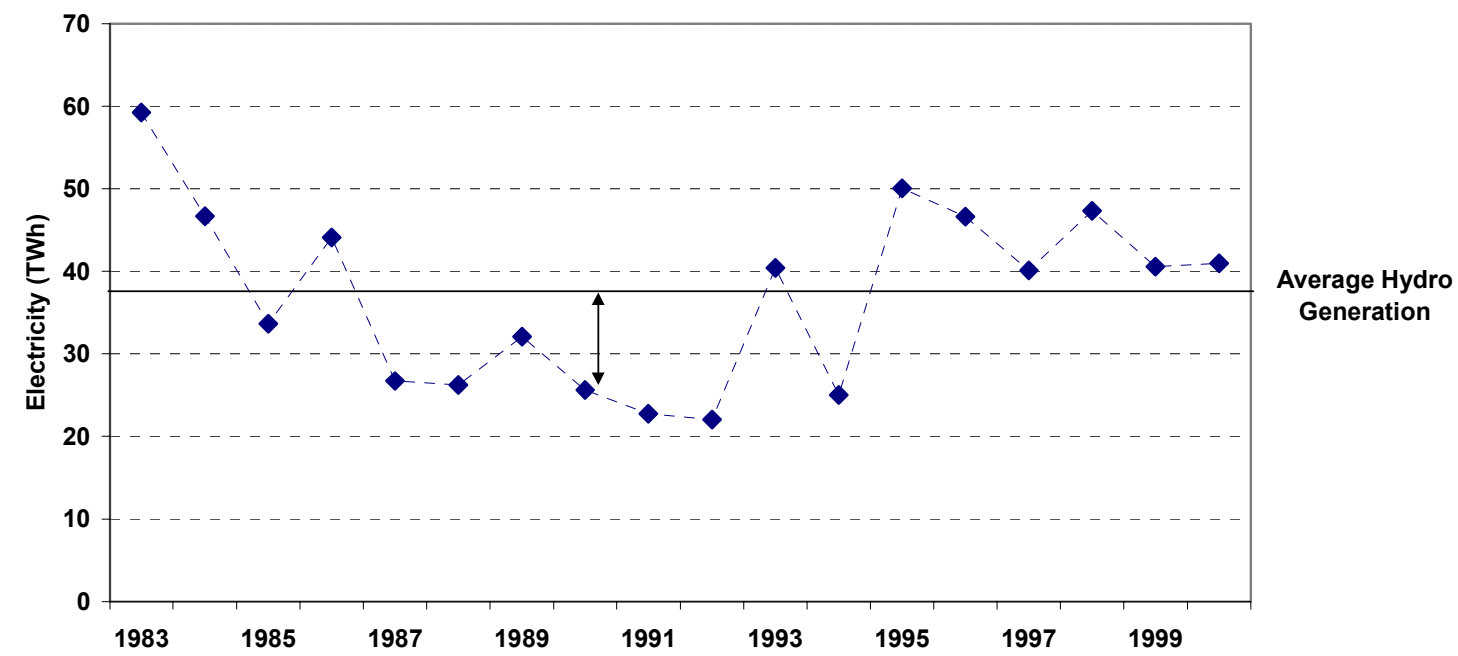

Figure 2. Total Annual Hydro Generation in CA, 1983-2000 and Long Run Average

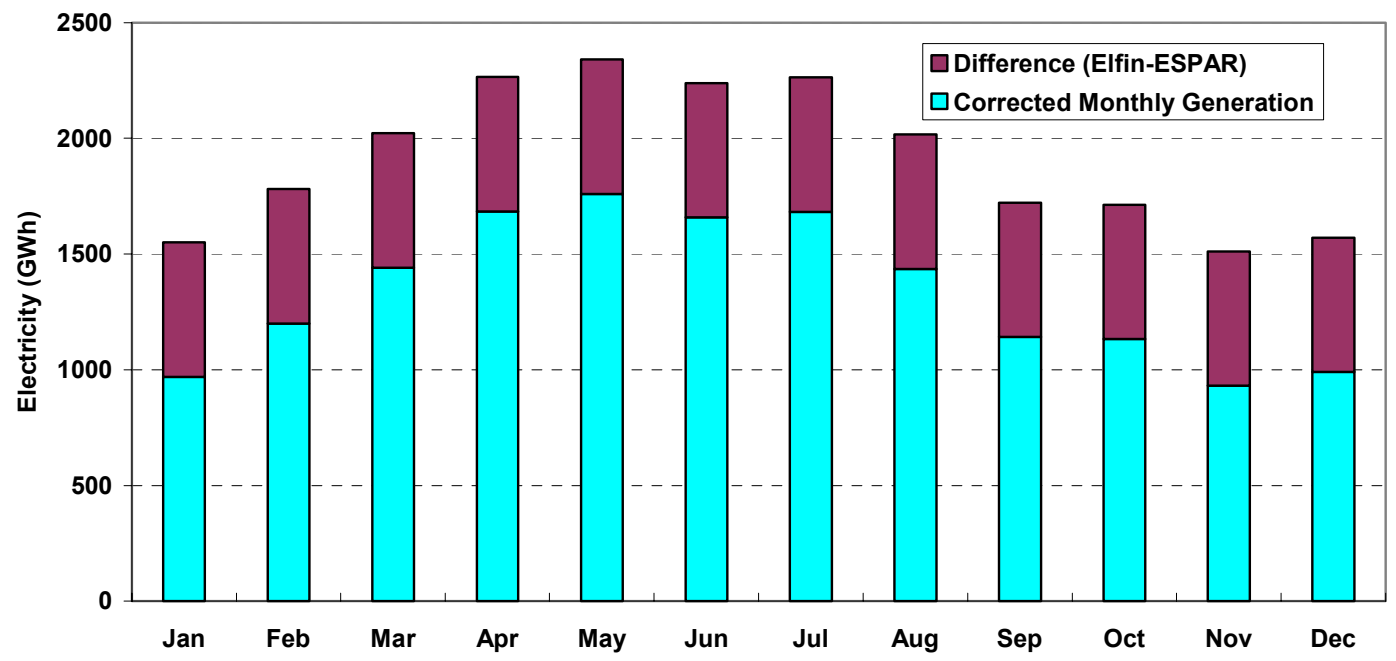

Figure 3. Corrected 1990 Monthly Hydro Generation for PG\&E

\section{Correct Nuclear Generation for 1990 Conditions}

With a method similar to that used to adjust hydro generation, ESPAR 92 data on utility annual nuclear generation for 1990 were used to adjust Elfin's forecast for nuclear energy (CEC, 1993). The nuclear generation data in the Elfin files were matched to these figures. The monthly patterns of the generation (e.g. refueling schedule) were left the same but the annual figures were matched. 
a) Identified the nuclear refueling schedule and back-cast for 1990.

In the Elfin files, the refueling schedule for the nuclear power plants is not available for the year 1990, but this schedule can be inferred by observing the pattern of the refueling schedule in years for which the data are available. Refueling generally occurs every 16 to 20 months and lasts for three or four consecutive months, during which the unit is off-line. This pattern of refueling cycle was identified for each plant and the refueling schedule was inferred for the year 1990.

b) Matched the annual generation in Elfin with actual generation in the year 1990.

The annual generation of nuclear plants is determined by three parameters: plant capacity, forced outage rate, and maintenance outage rate (MOR). Plant capacity is a fixed parameter while MOR is determined by the refueling schedule. Thus, the final step in adjusting the annual nuclear generation was matching the forced outage rate of the nuclear plants. Figure 4 illustrates the resulting 1990 pattern of monthly generation for Diablo Canyon Units 1 \& 2 .

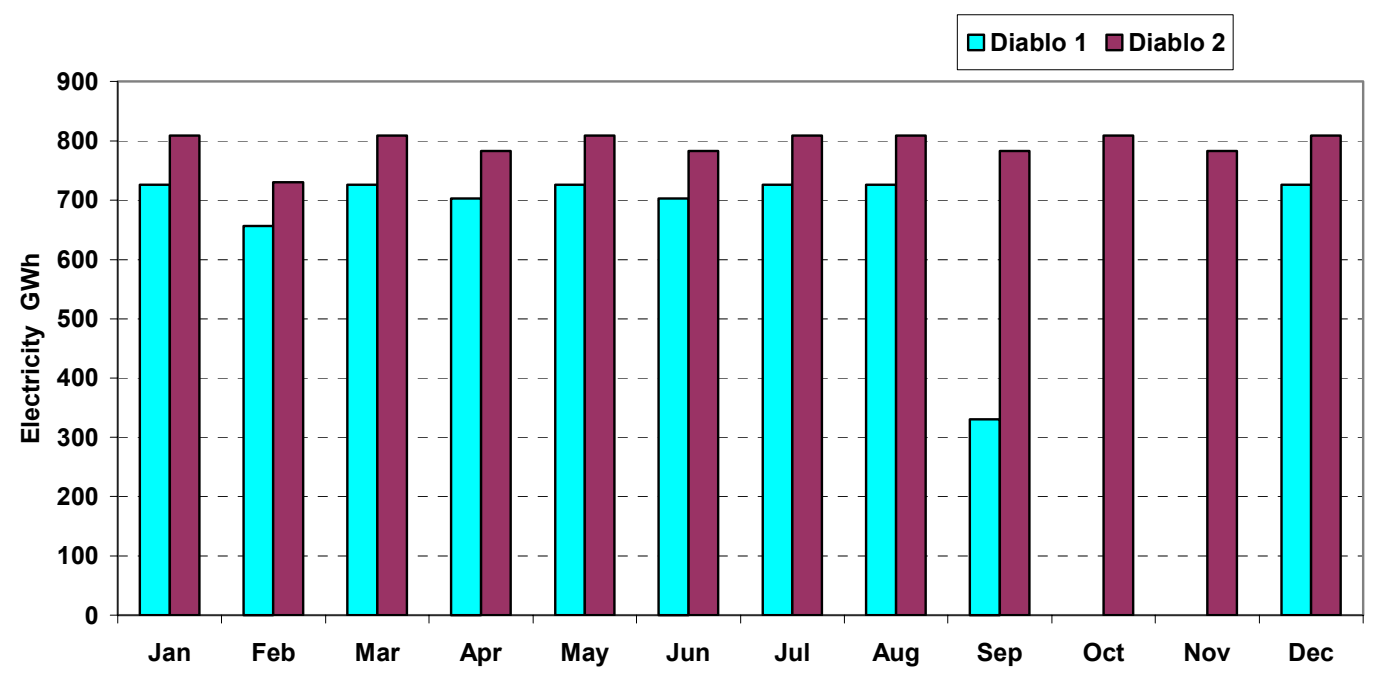

Figure 4. 1990 Monthly Pattern of Nuclear Generation - Diablo Canyon Units $1 \& 2$

The data indicate that there was no planned outage for Diablo Canyon Unit 2 and the variation in the monthly generation is due to unexpected outages. It was also inferred that Diablo Canyon Unit 1 was refueled in the months of September, October, and November. As seen in the above figure, Elfin captures the effect both of the planned and unexpected outages.

\section{Correcting Actual Natural Gas Prices for 1990}

Natural gas prices for electric utilities were obtained from the EIA (U.S. DOE/EIA, 2001e) and were used in all Elfin files. It was important to correct for this because a large difference in natural gas prices will affect the marginal costs of generators using gas and may thus lead to higher or lower demand for gas-fired generation. 


\section{METHOD FOR DETERMINING AVERAGE AND MARGINAL ELECTRICITY CO $\mathrm{O}_{2}$ EMISSIONS FACTORS}

AEFs are readily calculated from Elfin outputs. Total emissions are reported and can be simply divided by total generation. Calculating the MEF, however, presents more of a challenge. The MEF is the weighted sum of the AEFs of the plants that run on the margin, i.e., the plants dispatched to follow the load. For the calculation of MEFs, an appropriate load decrement needs to be imposed, and dividing the change in total emissions by the change in total generation yields the MEF. The appropriate load decrement should only capture the effect of the plants running on the margin. The load decrement should be small, but if an adjustment is too small, it could yield statistically noisy results. The appropriate value was determined by undertaking a sensitivity analysis of MEF with respect to various load decrements. Figure 5 illustrates this sensitivity analysis for PG\&E. The MEF result was surprisingly stable up to a load decrement of around $5 \%$, so a test load decrement of $3 \%$ was chosen.

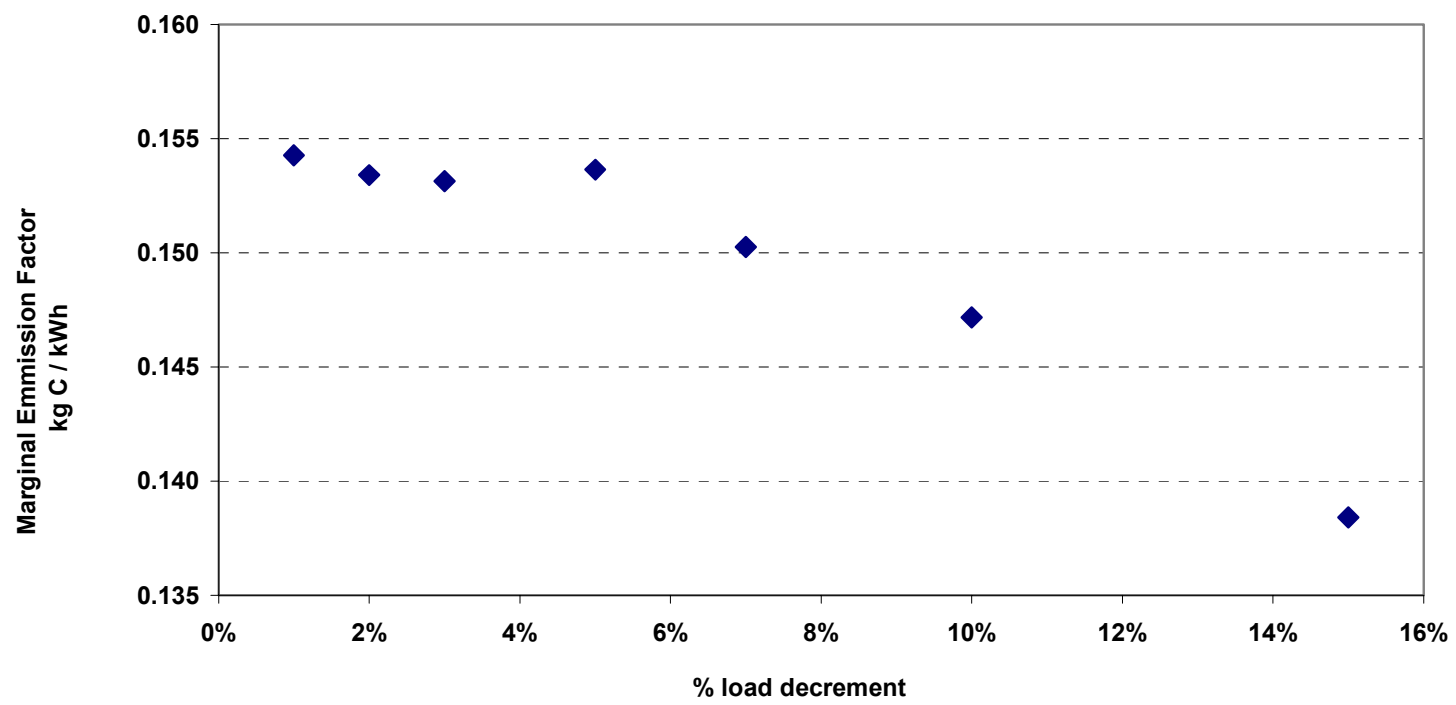

Figure 5. Example Load Decrements and the Corresponding MEF Estimate for PG\&E

Generation from various sources can be defined to fall into the following categories.

A: Generation from in-state plants owned by California utilities and non-utility generators

B: Generation from out-of-state plants owned by California utilities

C: Imports from out-of-state

D: Exports to other states

Emissions from all plants from each category mentioned above were identified after running Elfin files for the year 1990, and the value for $A+B+C$ calculated for the purposes of estimating AEFs and MEFs. ESPAR gives utility-specific annual values for "electrical energy consumed by California end users, out-of-state exports, and T\&D losses". In other words, the ESPAR values include all in-state generation as well as that 
out-of-state plants owned by California utilities and other imports. Therefore, Elfin results include emissions from exports, and a method was devised to extract them.

In-state only emissions were also calculated to provide comparisons to inventories. These were calculated as follows:

Emissions produced in-state $=$ Total emissions associated with generation modeled in Elfin $(\mathrm{A}+\mathrm{B}+\mathrm{C}+\mathrm{D})-$ Emissions associated with imports $(\mathrm{C})-$ emissions associated with out of state plants owned by CA utilities $(B)=A+D$.

\section{E. RESULTS}

Elfin runs were conducted for the following California electric utilities: SCE, PG\&E, LADWP, SDG\&E, SMUD, and the IID. The annual results are shown in Table 15. SCE emitted by far the most carbon and had a high marginal emissions rate of 0.165 $\mathrm{kgC} / \mathrm{kWh}$, but SDG\&E and LADWP had higher rates at $0.201 \mathrm{kgC} / \mathrm{kWh}$ and 0.191 $\mathrm{kgC} / \mathrm{kWh}$ respectively. The result for SMUD is not credible, probably because the embedded emissions factors are inaccurate or missing. Since SMUD provides a relatively small share of California's electricity, this was not investigated further. While the range in MEFs is not huge, 0.153 to $0.201 \mathrm{kgC} / \mathrm{kWh}$ among the four largest utilities, the high rates for LADWP and SDG\&E do suggest that coal plants become marginal at some times.

The differences between the AEFs and MEFs are interesting. The greatest gap occurs for PG\&E, a UDC with a large share of hydro and nuclear in the baseload, but predominantly gas on the margin. Given that PG\&E represents such a large share of total state emissions, the possible inaccuracies of using AEF to estimate $\mathrm{CO}_{2}$ savings from reduced electricity consumption are clear. LADWP is the only UDC to have an MEF lower than the AEF, but the results are close, making it the only case in which using AEF would be a reasonable estimate of MEF. One piece of conventional wisdom that is often mentioned is that the EF of an older, somewhat inefficient natural gas plant could serve a reasonable proxy for the MEF of California UDCs because this type of plant is prevalent and will often be marginal. Taking the Pittsburg facility as an example, its AEF (not counting any T\&D losses) is approximately $0.148 \mathrm{kgC} / \mathrm{kWh}$, a close approximation to the MEF of PG\&E and a reasonable estimate of SCE's. However, this simplified approach would not yield a robust estimate for the other utility areas.

Table 15. 1990 Total Electricity Generation, Emissions, AEF, and MEF by UDC

\begin{tabular}{l|c|c|c|c|c|c}
\hline & $\begin{array}{c}\text { Electricity } \\
\text { (TWh) }\end{array}$ & $\begin{array}{c}\text { Pct of } \\
\text { Electricity }\end{array}$ & $\begin{array}{c}\text { Emissions } \\
\text { (MtC) }\end{array}$ & $\begin{array}{c}\text { Emissions } \\
(\mathbf{\%})\end{array}$ & $\begin{array}{c}\text { AEF } \\
\text { (kg C/kWh) }\end{array}$ & $\begin{array}{c}\text { MEF } \\
(\mathbf{k g} \text { C/kWh) }\end{array}$ \\
\hline PG\&E & 101.8 & $43 \%$ & 7.16 & $27 \%$ & 0.070 & 0.153 \\
SCE & 89.2 & $37 \%$ & 11.79 & $45 \%$ & 0.132 & 0.165 \\
LADWP & 24.3 & $10 \%$ & 4.73 & $18 \%$ & 0.195 & 0.191 \\
SDG\&E & 16.7 & $7 \%$ & 2.21 & $8 \%$ & 0.132 & 0.201 \\
SMUD & 4.0 & $2 \%$ & 0.09 & $0.4 \%$ & 0.024 & 0.002 \\
IID & 2.4 & $1 \%$ & 0.15 & $1 \%$ & 0.062 & 0.123 \\
\hline Total & $\mathbf{2 3 8 . 4}$ & & $\mathbf{2 6 . 1 3}$ & & $\mathbf{0 . 1 1 0}$ & \\
\hline
\end{tabular}

Generation and emissions associated with out-of-state power plants, imports, and exports were estimated separately for 1990 and results appear in Table 16. The second column 
presents the results for the total generation modeled in Elfin files, while the other columns separately list the generation and emissions associated with imports, out-of-state power plants, and exports. These values were determined by looking at details of plantby-plant generation in the Elfin files.

\section{Table 16. Emissions from Out of State Power Plants, Imports, and Exports}

\begin{tabular}{l|c|c|c|c|c|c}
\hline \multirow{2}{*}{ Utility } & \multicolumn{2}{|c|}{ Out-of-State Power Plants } & \multicolumn{2}{|c|}{ Imports $^{\mathrm{a}}$} & \multicolumn{2}{c}{ Exports $^{\mathbf{b}}$} \\
\cline { 2 - 7 } & $\begin{array}{c}\text { Electricity } \\
\mathrm{TWh}\end{array}$ & $\begin{array}{c}\text { Emissions } \\
\mathrm{MtC}\end{array}$ & $\begin{array}{c}\text { Electricity } \\
\mathrm{TWh}\end{array}$ & $\begin{array}{c}\text { Emissions } \\
\mathrm{MtC}\end{array}$ & $\begin{array}{c}\text { Electricity } \\
\mathrm{TWh}\end{array}$ & $\begin{array}{c}\text { Emissions } \\
\mathrm{MtC}\end{array}$ \\
\hline PG\&E & $\mathrm{n} / \mathrm{a}$ & $\mathrm{n} / \mathrm{a}$ & 12.21 & 0.88 & - & - \\
SCE & 14.43 & 2.92 & 4.15 & 0.29 & 0.78 & 0.12 \\
LADWP & 14.15 & 3.50 & 4.29 & 0.34 & -- & - \\
SDG\&E & $\mathrm{n} / \mathrm{a}$ & $\mathrm{n} / \mathrm{a}$ & 7.07 & 1.03 & - & - \\
SMUD & $\mathrm{n} / \mathrm{a}$ & $\mathrm{n} / \mathrm{a}$ & 1.57 & 0.08 & - & - \\
IID & 0.28 & 0.08 & -- & - & - & - \\
\hline Total & $\mathbf{2 8 . 8 6}$ & $\mathbf{6 . 5 2}$ & $\mathbf{2 9 . 2 8}$ & $\mathbf{2 . 6 5}$ & $\mathbf{0 . 7 8}$ & $\mathbf{0 . 1 2}$ \\
\hline
\end{tabular}

${ }^{a}$ Elfin reported negligible imports from other states for IID.

b Elfin reported negligible exports to out-of-state utilities for all UDCs except SCE.

Figure 6 shows the shares of electricity and emissions coming from the four generation types. Coal plants owned by California UDCs outside the state have a dramatic effect on the pattern of emissions. These plants contribute $25 \%$ of the carbon emissions, while supplying only $12 \%$ of the energy. Exports are negligible and do not have a discernable impact on the total emissions or the emissions factors. Elfin does not provide emissions factors for exports. However, the MEF of a utility may reasonably be used as a proxy for the EF of its exports because the costliest electricity (electricity generated by the plants running at the margin) is generally used for exports. In this era of utility regulation, resources were generally applied to meet native requirements first, and exports were only considered if excess capacity was available.

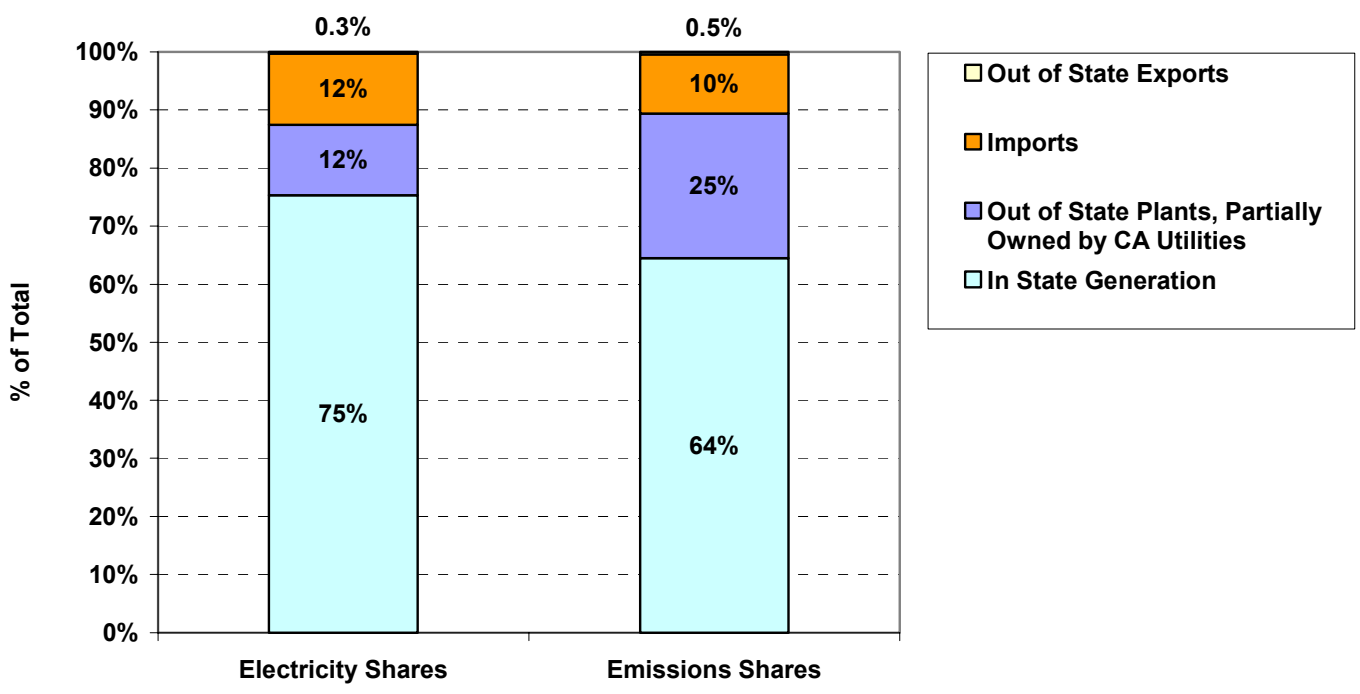


Figure 6. Shares of Electricity Generation and Emissions from Four Generation Types

Statewide results are obtained by aggregating the results obtained for all the six utilities, shown in the last rows of Table 15 and Table 16. Table 17 shows the statewide results for California consumers' carbon responsibility. It also represents the total emissions generated in the state.

Table 17. California Electricity Emissions Factors under Two Approaches

\begin{tabular}{l|c|c|c}
\hline Method & $\begin{array}{c}\text { Electricity } \\
\text { (TWh) }\end{array}$ & $\begin{array}{c}\text { Emissions } \\
\text { (MtC) }\end{array}$ & $\begin{array}{c}\text { AEF } \\
\text { (kgC/kWh) }\end{array}$ \\
\hline Allocation Based on End Use* & 237.7 & 26.0 & 0.109 \\
In-State Only** & 180.0 & 17.0 & 0.094 \\
\hline * Elfin Total (A+B+C+D) - Out-of-state Exports (D) $=\mathrm{A}+\mathrm{B}+\mathrm{C}$ \\
** Elfin Total (A+B+C+D) - Out of state power plants (B) - Imports (C)=A+D
\end{tabular}

The emissions factor for California electricity end-use is considerably higher than the emissions factor for electricity actually generated in the state. This is primarily because imports and generation from out-of-state power plants (owned by CA utilities) provide a significant portion of California consumers' demand, and this electricity is largely generated by coal. However, the higher embedded carbon content of this electricity is offset to some degree by relatively low-carbon power from the Northwest.

\section{F. PROSPECTS FOR THE ELFIN MODEL}

The findings calculated from Elfin simulations clearly demonstrate the importance of using models that can provide utility-specific AEFs and MEFs. Elfin estimates MEFs more accurately than the LDC method because it actually performs a simulation of dispatch of power plants considering a load duration curve, taking care of unit failures and variations in seasonal and sub-period conditions. Since the difference in AEF and MEF is significant in the case of most California utilities, the AEF cannot generally be used as an approximation for the MEF. More accurate estimation of the MEF is critical, which demonstrates the need for using models like Elfin, especially in the case of utilities that have many different types of plants running at the margin.

Though actual 1990 data were entered for most of the critical parameters that would affect emissions, more precise replication of 1990 conditions is possible. For example, in this exercise, hydro generation was matched to the actual annual total, leaving the pattern of monthly generation the same as the average assumed in existing Elfin files. More accurate estimates of emissions factors can be obtained by using actual monthly hydro generation data. In addition, information on actual nuclear power plant refueling and other outages can be obtained.

A strength of Elfin lies in the opportunity it provides for further levels of analytical sophistication. In addition to the annual and monthly estimates derived for this report, Elfin could provide time-of-day EFs as well. Elfin can be used to conduct sensitivity 
analyses of the relative importance of numerous factors that affect emissions. Elfin can be used not only as a forecasting model, it can also serve as an analytical tool to examine various principles and methods used in the estimation of emissions factors. The main constraint on its future use will be the availability of data in the current structure of the electricity industry. 


\section{METHODOLOGY FOR CALCULATING ELECTRICITY EMISSIONS FACTORS FOR THE MID-1990S FORWARD: SIMPLE LOAD DURATION CURVE APPROACH}

\section{A. DESCRIPTION OF METHOD}

As mentioned above, Elfin, as well as many common production cost models, uses a load duration curve (LDC) approach. Because electricity cannot be economically stored from one time period to the next on UDC scales of operation, precisely simulating operations of a power system requires estimating its state at every instant through time. Many models attempt to replicate what might actually happen as a system is operated hour by hour and the various generating assets are dispatched to meet electricity demand. The LDC approach is simply to reorder system loads such that hours with similar loads are grouped together and treated similarly. This can allow for an approximation to system dispatch that is accurate enough to produce satisfactory results for time scales such as a year or month.

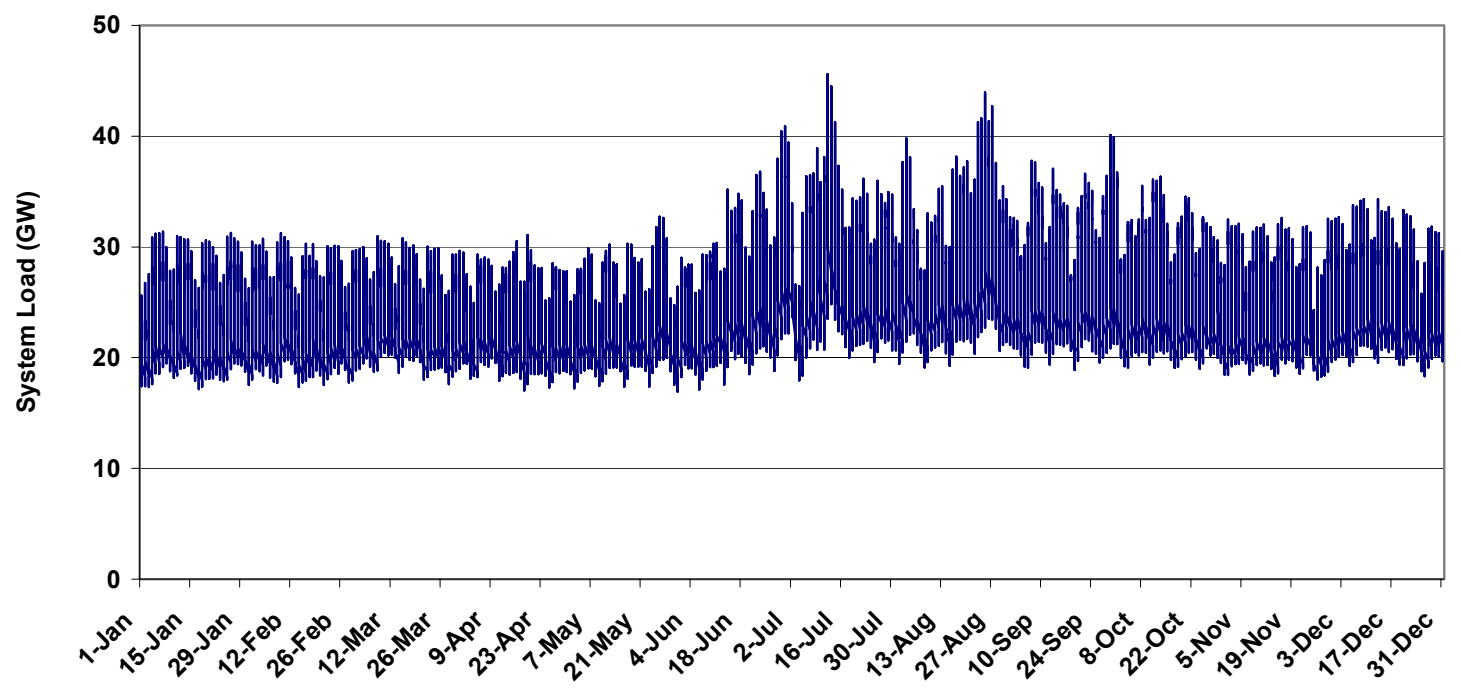

Figure 7. Actual 1999 CAISO Load

Figure 7 shows the CAISO hourly load for 1999, in GW. Figure 8 shows the total CAISO load from Figure 7 reordered as an LDC. The $\mathrm{x}$-axis shows all hours during a year, while the y-axis is the system load, ordered from hour with the highest load to the lowest load. (Note that an LDC is somewhat akin to a cumulative probability function.) The highest load reached during the year at hour 1 on the $\mathrm{x}$-axis is called the system peak, while the minimum load, which was exceeded in all hours, is called the baseload. 


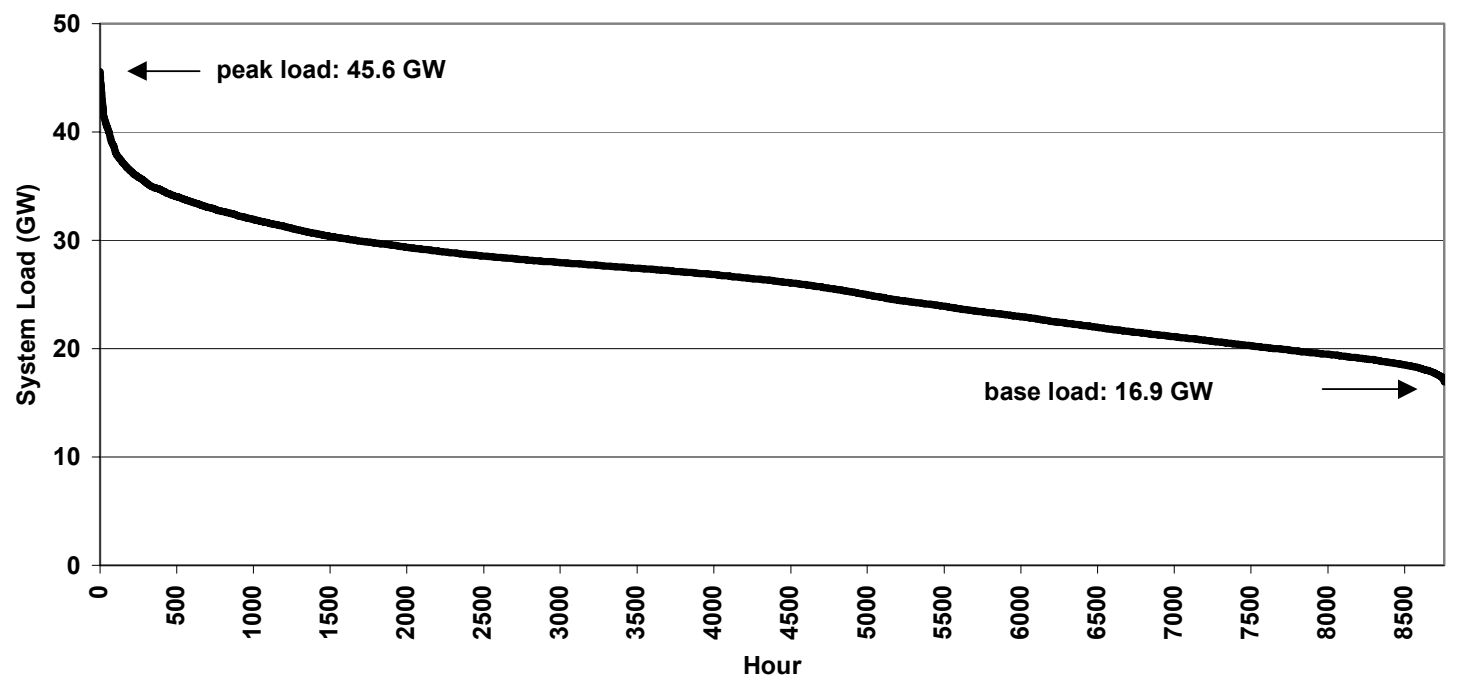

Figure 8. 1999 CAISO Load Duration Curve

Any reduction in electricity demand will result in a lowering of the LDC. Since the LDC has power $(\mathrm{GW})$ on the y-axis and time on the $\mathrm{x}$-axis $(\mathrm{h})$, the area under it represents energy (GWh). That is, the integral of the LDC represents the total energy demand on the system over the period represented. Traditionally, generating resources of a control area are dispatched in a fairly rigid order called the merit order. Therefore, one can picture a different set of generating assets serving the baseload demand than serving that fraction of demand that falls immediately under the curve. The later generating assets are often referred to as the load following resources. Since electricity cannot be stored through time as electricity demand rises and falls, these are the generators that increase or decrease output as load changes. If electricity demand falls, the load duration curve will lower and output of the load following resources decline, whereas the baseload resources will remain unaffected. In other words, the load following resources are the marginal generators. If the load following resources can be identified, these are the generators whose output and carbon emissions will decrease as a result of electricity conservation. The key to estimating the effect on carbon emissions of decreased demand, therefore, hinges on successfully identifying the load following units.

In the real world, there are many reasons why the use of plants or contracted power purchases to meet load is restricted, but overall, the use of resources can be approximated by economic dispatch. Economic dispatch is based on the assumption that UDCs will attempt to meet their electricity demand at minimum cost. For cost to be minimized overall, the combination of assets being used at any point in time must be the cheapest combination that can meet load. If this were not true, a logical contradiction would result because costs could be lowered overall by substituting a cheaper resource for one being used. 


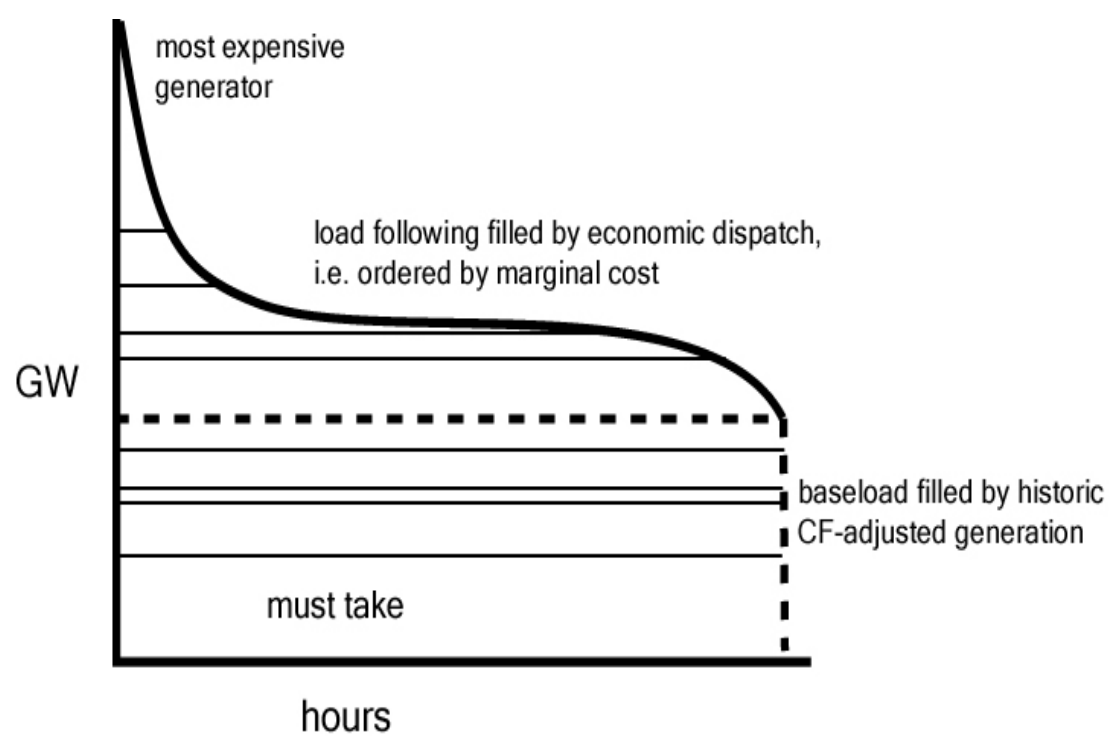

Figure 9. Merit Order Dispatch

If the LDC is filled up from the bottom using least to most expensive sources, a schematic representation of economic dispatch can be achieved, and the load following resources identified. Unfortunately information about the operating costs of the various generation assets is generally not readily available. It is possible to estimate costs using fuel costs and old generating station data, such as are found in the Elfin input files, but this would be a tedious and unreliable process. If we assume that historic use of a plant has been approximately economic, the amount of time that plant has been used in past years is a useful indicator of its operating cost. Therefore, if generators are filled into the load duration curve in order of their historic capacity factors, then the result will be an approximation to economic dispatch.

Figure 9 shows how the curve in this study was actually filled in. Some forms of generation are always used when available. These can be assumed to be in the baseload and are called must take resources. The two notable examples are hydro and nuclear generation, which are always used when available because these forms of electricity generation have low marginal costs. Also, CHP generation can be considered must take because these plants are operating in large measure in ways driven by their heat loads and electricity output is unlikely to vary much in the short run. After these resources have been filled into the curve, the remaining resources can be filled in order of decreasing capacity factor, which as mentioned above can serve as a proxy for variable operating cost.

Figure 10 shows how once the load following resources have been identified, an estimate of marginal emissions can be derived. In this example, just four generators end up on the margin. A weighted sum of the emissions rates of the generators in which the weights are the fractions of time, fi, that each spends on the margin will now provide an estimate of the marginal emissions rate for the period. 


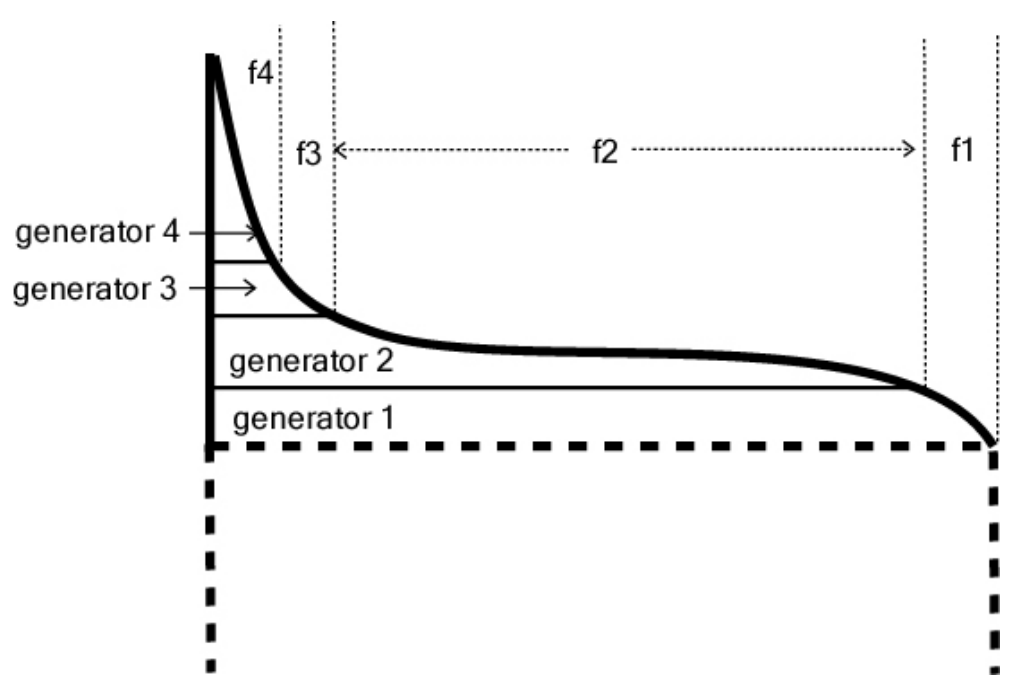

Figure 10. Estimating the Marginal Emissions Factor

In this example, four generators are identified as marginal, and the times each is marginal over the period are shown by the fractions, fi. The overall MEF can therefore be calculated as the weighted sum of the emissions factors of the four generators where the weights are the fractions of time spent on the margin:

$$
\mathrm{MEF}=\mathrm{AEF} 1 * \mathrm{f} 1+\mathrm{AEF} 2 * \mathrm{f} 2+\mathrm{AEF} 3 * \mathrm{f} 3+\mathrm{AEF} 4 * \mathrm{f} 4
$$

One problem with this approach is that in a restructured wholesale electricity market, identifying the resources that will be used to meet the load of any UDC is not a trivial undertaking. Here it is assumed that power plants serve the load of the UDC in whose service territory they reside.

\section{B. DATA SOURCES}

The publicly available plant data used by EIA as input to its National Energy Modeling System (NEMS) was obtained directly from EIA. The NEMS model is used each year to produce EIA's Annual Energy Outlook (AEO). The data used here are from the 2001 AEO, which would primarily include plant data from 1999 (US DOE/EIA, 2001j). It is also possible to obtain older NEMS input files from EIA, so that a historical analysis of trends could be performed. The advantage of using the NEMS plant data input file is that the data has already been compiled in a readily useable electronic format. As with the PDS method, load data were taken from CAISO (2001) for the CAISO UDCs and from FERC (2001) for LADWP.

\section{IMPLEMENTATION}

The variables in the NEMS plant data that were used for this analysis include the company id, the power area, the regional code for the location of the plant owner, the state in which the plant is located, the summer and winter capacities of the plant, the heat rate, average capacity factor, the monthly capacity factors, the primary, secondary, and 
tertiary fuel codes and fuel shares, the variable O\&M costs, $\mathrm{SO}_{2}$ control cost, and the percent of the plant's power that is delivered to the grid.

The "power area" variable in the EIA data set was used to decide which plant to assign to which utility, rather than the "company id." There were over 300 companies in the NEMS plant data set, including many small ones. Using the "power area" variable was a way to assign these small plants to a local utility. Because SMUD is located in the PG\&E power area, and because data that is reported to the CAISO for PG\&E includes SMUD, some of results are reported for PG\&E and SMUD together. SMUD's company id was also used to separate out SMUD's plants from the others in the PG\&E power area, and some results are reported separately. Results are explicitly labeled as being either for PG\&E, for SMUD, or for PG\&E+SMUD.

The average capacity of each plant in the NEMS data set was calculated by taking the average of the summer and winter capacity. ${ }^{29}$ The gross generation of electricity for each plant was calculated by multiplying the average capacity times the average capacity factor times the number of hours in a year (8760). The electricity delivered to the grid was then calculated by multiplying the gross generation times the reported percent of plant electricity delivered to the grid.

In order to calculate carbon emissions and marginal costs of electricity generation, the primary fuel code from the NEMS data was used, ${ }^{30}$ and then the values for carbon emissions and costs by fuel type that are reported in Table 18 were used.

\footnotetext{
29 The NEMS data also reports the plant's nameplate capacity. Typically this number is larger than either the summer or winter capacity. It is assumed that the reported summer and winter capacity are a better representation of the actual capacity of the plant in operation.

${ }^{30}$ There was an anomaly in the NEMS data for many plants for which oil is the reported primary fuel. For many of these plants, natural gas was reported as the secondary or tertiary fuel, but the fuel shares for oil and gas were both reported as $100 \%$. For any plant that reported oil as the primary fuel and natural gas as the secondary or tertiary fuel, the plant was treated as a natural gas power plant.
} 
Table 18. Fuel Cost and Carbon Content Values by NEMS Fuel Code

\begin{tabular}{c|l|c|c}
\hline Code & Fuel type & $\begin{array}{c}\text { Fuel Cost } \\
\text { \$/10 } \mathbf{6}^{\mathbf{B} T U}\end{array}$ & $\begin{array}{c}\text { Carbon Content } \\
\text { (kgC/10 } \mathbf{B} \text { BTU) }\end{array}$ \\
\hline 1 & coal, old low SO2 & 1.19 & 26.4 \\
2 & coal, old mid SO2 & 1.26 & 26.4 \\
3 & coal, old high SO2 & 1.19 & 26.4 \\
4 & coal, new low SO2 & 1.19 & 26.4 \\
5 & coal, new mid SO2 & 1.26 & 26.4 \\
6 & coal, new high SO2 & 1.19 & 26.4 \\
7 & coal, scrubbed & 1.19 & 26.4 \\
8 & fuel oil & 4.89 & 20.9 \\
9 & heavy oil, low S & 3.50 & 20.9 \\
10 & heavy oil, high S & 3.30 & 20.9 \\
11 & natural gas, firm & 2.68 & 14.5 \\
12 & natural gas, inter & 2.68 & 14.5 \\
13 & natural gas, competitive & 2.68 & 14.5 \\
14 & nuclear & 0.00 & 0.0 \\
15 & other & 0.00 & 0.0 \\
16 & biomass, wood & 1.00 & 0.0 \\
17 & refuse/tires & 0.50 & 0.0 \\
18 & hydro & 0.00 & 0.0 \\
19 & pumped storage & 0.00 & 0.0 \\
20 & wind & 0.00 & 0.0 \\
21 & geothermal & 0.00 & 0.0 \\
22 & solar & 0.00 & 0.0 \\
\hline
\end{tabular}

Sources: Natural gas cost from Natural Gas Annual (U.S. DOE/EIA 2000b), average price of natural gas delivered to utilities in 1999. Coal prices are from the Coal Quarterly 1999, Quarter 4, Table 27 (U.S. DOE/EIA 2000c), which reports average price to electric utilities of coal by sulfur content. The fourth quarter report was used - this reports average prices for the entire year. The carbon content of fuels were taken from the IPCC Guidelines for GHG Inventories (IPCC, 1996). The numbers are comparable to those obtained by the methods described in section IV.B.

Carbon emissions per $\mathrm{kWh}$ of generation were calculated as follows. The carbon content for each fuel type was used, as reported in $\mathrm{kgC} / 10^{6} \mathrm{BTU}$ (see Table 18). The reported heat rate for each plant, in BTU of fuel per $\mathrm{kWh}$ of electricity generated, ${ }^{31}$ was then used to convert these carbon factors into $\mathrm{kgC}$ per $\mathrm{kWh}$ of electricity, and this value was then multiplied by the electricity generation to get the number of $\mathrm{kgC}$ produced by each plant. The generation was not adjusted to reflect the share that went to SB 1305 sales, however such an adjustment could be done by going through the NEMS data plant by plant, and reducing each plants generation by the SB 1305 sales, as described in Section III.C.6 of this report.

\footnotetext{
${ }^{31}$ Some of the heat rates in the NEMS plant data appear to be unrealistically high. There were some thermal plants with reported heat rates as high as $40,000 \mathrm{BTU} / \mathrm{kWh}$, whereas the average for a plant in the US is typically in the range of 10,000 to $12,000 \mathrm{BTU} / \mathrm{kWh}$. For any thermal plant whose reported heat rate was greater than $20,000 \mathrm{BTU} / \mathrm{kWh}$, the value was lowered to $12,000 \mathrm{BTU} / \mathrm{kWh}$. The reason the heat rates in the 12,000 to $20,000 \mathrm{BTU} / \mathrm{kWh}$ range were not adjusted is that, by spot checking the data for a few plants on the EIA Forms 759 and 860B, some plants were found whose heat rates are this high. The plants affected by this adjustment account for a relatively small portion of the generation.
} 
The marginal cost per $\mathrm{kWh}$ for each plant was calculated as follows. The plant's heat rate was multiplied by the cost per $10^{6} \mathrm{BTU}$ of the fuel (from Table 18). This fuel cost was then added to the variable O\&M cost, and the $\mathrm{SO}_{2}$ control cost from the NEMS plant $\mathrm{data}^{32}$, to obtain a value for the marginal cost per $\mathrm{kWh}$.

The next step was to determine the net imports for each power control area. Table 19 shows the calculation of net imports for each utility region. Net imports are calculated by taking the difference between the system load for each utility, and its generation, as calculated from the NEMS data. Load for PG\&E+SMUD, SCE, and SDGE are calculated by taking the sum of the hourly loads as reported by CAISO for 1999. The CAISO total is also shown. Load for LADWP, which is not a member of CAISO, is the sum of hourly loads as reported to FERC. The PG\&E+SMUD load is assigned to PG\&E and SMUD by assuming each utility's share of load is proportional to its share of generation. The load for all of California was estimated from the NEMS data by assuming that the CAISO+LADWP load would be the same fraction of the California total load as the CAISO+LADWP generation is of California total generation (90.3\%).

Considering that the generation was calculated from one dataset (NEMS), and the load from another (CAISO, or FERC), the values calculated for generation, load, and net imports match reasonably well with values reported by the CEC for each of these quantities.

Table 19. Calculation of Net Imports by Region

\begin{tabular}{l|c|c|c}
\hline & $\begin{array}{c}\text { Own Generation } \\
\text { (from NEMS) }\end{array}$ & Load & $\begin{array}{c}\text { Calculated Net } \\
\text { Imports }\end{array}$ \\
\hline PG\&E & 98.63 & 105.81 & 7.18 \\
SMUD & 4.39 & 4.71 & 0.32 \\
PG\&E+SMUD & 103.02 & 110.52 & 7.50 \\
SCE & 64.98 & 98.15 & 33.17 \\
SDGE & 9.95 & 18.84 & 8.89 \\
CAISO & 178.12 & 227.52 & 49.39 \\
LADWP & 21.99 & 25.07 & 3.08 \\
ISO+DWP & 200.12 & 252.59 & 52.47 \\
\hline All CA, NEMS & 221.73 & 280.07 & 58.34 \\
\hline All CA, CEC & 226.32 & 275.80 & 49.49 \\
\hline
\end{tabular}

In order to include imports in the LDC calculation, it is necessary to create one or more "dummy" plants in the list of generators to represent imports. It was assumed that all imports to the PG\&E+SMUD region would come from the northwest, and that all imports to SCE, SDGE, and LADWP would come from the southwest. From the plant data described in Section III, it was determined that $72.4 \%$ of generation in the northwest

\footnotetext{
${ }^{32}$ The NEMS monetary values, which are reported as $1987 \$$, were converted to $1999 \$$.

${ }^{33}$ In the NEMS plant data, LADWP is reported to own $100 \%$ of the Intermountain power plant. However, LADWP's actual share of generation from this facility in 1999 was only $62.785 \%$ (LADWP 2002), therefore the generation from this plant attributed to LADWP was reduced accordingly. The entire generation $(100 \%)$ of this plant was included in the "All CA, NEMS" total.
} 
is derived from non-thermal sources, with an emissions factor of zero, and $27.6 \%$ of generation comes from thermal sources whose average emissions factor is 0.251 $\mathrm{kgC} / \mathrm{kWh}$. Southwest imports consist of $22.3 \%$ non-thermal imports, and $77.7 \%$ thermal. We represented the thermal and non-thermal imports as two separate dummy plants, with capacity factors of one, and with generation equal to the appropriate fraction of each region's net imports.

The plants were then placed in the order of probable dispatch, and then the LDC calculation was performed. The plants were ordered as follows. Nuclear plants were placed first in the plant order, then non-thermal imports, then renewables such as wind, geothermal, biomass, and municipal solid waste. The reason for placing renewables early in the dispatch order is that these fuels are "must take" fuels. The electricity from these plants generally must be used as it's being generated (either due to the nature of the fuel, such as wind, or due to contracts that require utilities to purchase the power, such as is usually the case with biomass or refuse, or because, in the case of nuclear, the operation of plants is inflexible). Cogeneration facilities were placed next in the dispatch order, again because they generally have contracts which require utilities to purchase the power they generate and because output is unlikely to change in the short run. Hydro plants were then placed next in the probable dispatch order. The remaining plants, or all thermal facilities other than cogeneration, including thermal imports, were then ordered first by their capacity factor, then, within a given capacity factor, i.e. for plants whose capacity factor was the same, by their marginal cost. As explained in section V.A., the reason to order plants by their capacity factor is that this gives empirical information about which plants were used as baseload plants vs. load-following plants - the higher the capacity factor, the more the plant was operated and the lower its costs are likely to be.

Load duration curves were constructed by first obtaining the hourly load profiles for 1999 for the three CAISO utilities, which are PG\&E (including SMUD), SCE, and SDGE, and for the largest non-ISO utility, LADWP. Each of these profiles was then reordered from highest to lowest load, as described in section V.A, to produce load duration curves for each of these regions. The annual load for each region can also be calculated by taking the sum of the hourly loads for each region.

\section{RESULTS}

Table 20 shows the electricity generation by fuel type as calculated from the NEMS plant data - the upper portion reports generation in TWh, and the lower portion reports the percentage that each fuel type contributes to electricity generation. These values include electricity generated in out-of-state plants owned by California utilities, but do not include other imports, which are calculated separately, as discussed later in this section.

Table 21 shows generation by fuel type, as reported by the CEC (2001b), for 1999 . These values are also for in-state plus utility-owned out-of-state plants. The values calculated from the NEMS data set match quite well to those reported by the CEC. Total generation from the NEMS data set was calculated to be $222 \mathrm{TWh}$. This compares well to the value of 226 TWh of electricity generation from California plants (including utility-owned outof-state plants) reported by the CEC for 1999. The fuel mix calculated from the NEMS 
data also compares well to CEC values - the NEMS fuel mix includes somewhat less natural gas (30\% vs. 37\% from CEC), and slightly more of everything else.

\begin{tabular}{|c|c|c|c|c|c|c|c|}
\hline Fuel Mix (TWh) & Gas & Oil & Coal & Nuclear & Hydro & Other & Total \\
\hline PG\&E & 33.409 & 0.773 & 2.289 & 16.973 & 36.343 & 8.846 & 98.633 \\
\hline SMUD & 1.760 & 0.000 & 0.000 & 0.000 & 2.540 & 0.087 & 4.387 \\
\hline PG\&E + SMUD & 35.169 & 0.773 & 2.289 & 16.973 & 38.883 & 8.933 & 103.020 \\
\hline SCE & 19.473 & 0.028 & 12.326 & 19.500 & 5.910 & 7.739 & 64.976 \\
\hline SDGE & 5.424 & 0.746 & 0.000 & 3.693 & 0.006 & 0.079 & 9.948 \\
\hline ISO total & 60.066 & 1.547 & 14.615 & 40.166 & 44.799 & 18.923 & 180.116 \\
\hline LADWP & 4.180 & 0.000 & 15.060 & 1.705 & 1.047 & 0.000 & 21.992 \\
\hline All utilities & 67.052 & 2.092 & 40.303 & 43.639 & 47.156 & 21.482 & 221.725 \\
\hline$\overline{\text { Fuel Mix (\%) }}$ & Gas & Oil & Coal & Nuclear & Hydro & Other & \\
\hline$\overline{P G \& E}$ & $34 \%$ & $1 \%$ & $2 \%$ & $17 \%$ & $37 \%$ & $9 \%$ & \\
\hline SMUD & $40 \%$ & $0 \%$ & $0 \%$ & $0 \%$ & $58 \%$ & $2 \%$ & \\
\hline PG\&E + SMUD & $34 \%$ & $1 \%$ & $2 \%$ & $16 \%$ & $38 \%$ & $9 \%$ & \\
\hline $\mathrm{SCE}$ & $30 \%$ & $0 \%$ & $19 \%$ & $30 \%$ & $9 \%$ & $12 \%$ & \\
\hline SDGE & $55 \%$ & $7 \%$ & $0 \%$ & $37 \%$ & $0 \%$ & $1 \%$ & \\
\hline ISO total & $33 \%$ & $1 \%$ & $8 \%$ & $22 \%$ & $25 \%$ & $11 \%$ & \\
\hline LADWP & $19 \%$ & $0 \%$ & $68 \%$ & $8 \%$ & $5 \%$ & $0 \%$ & \\
\hline All utilities & $30 \%$ & $1 \%$ & $18 \%$ & $20 \%$ & $21 \%$ & $10 \%$ & \\
\hline
\end{tabular}

Table 21. Generation by Fuel Type as Reported by the California Energy Commission, for 1999

\begin{tabular}{l|l|l|l|l|l|l|l}
\hline & \multicolumn{1}{c|}{ Gas } & \multicolumn{1}{c|}{ Oil } & \multicolumn{1}{c|}{ Coal } & \multicolumn{1}{c|}{ Nuclear } & \multicolumn{1}{c}{ Hydro } & \multicolumn{1}{c}{ Other } & \multicolumn{1}{c}{ Total } \\
\hline Generation (TWh) & 84.703 & 0.055 & 36.327 & 40.419 & 41.627 & 23.185 & 226.316 \\
Generation (\%) & $37 \%$ & $0 \%$ & $16 \%$ & $18 \%$ & $18 \%$ & $10 \%$ & \\
\hline
\end{tabular}

Source: (CEC, 2001b)

Table 22 shows the 1999 average carbon emissions factors for the CAISO, and also separately for the three CAISO utilities, plus for LADWP, the largest non CAISO utility. The differences in average carbon emissions factors for the different utilities can be readily explained by examining the fuel mix for each utility, shown in Table 20. LADWP has by far the highest average carbon emissions factor because such a large fraction of its electricity $(68 \%)$ is generated by coal, while only a relatively small fraction $(13 \%)$ is generated by carbon free sources. SCE and SDG\&E's emissions factors are intermediate. SCE has a significant fraction of coal $(19 \%)$, but also has a fairly large portion of generation $(51 \%)$ from carbon free sources. SDGE has less electricity generation from carbon free sources than SCE (38\%), but also has no coal generation. PG\&E and SMUD have the lowest average carbon emissions factors because of both low coal generation ( $2 \%$ for PG\&E, $0 \%$ for SMUD) and high generation from carbon free sources $(63 \%$ for PG\&E, $60 \%$ for SMUD). 
Table 22. Average Carbon Emissions Factors for California Utilities, $\mathrm{kg} \mathrm{C} / \mathrm{kWh}$

\begin{tabular}{l|c|c}
\hline Utility & $\begin{array}{c}\text { AEF, in-state plus utility- } \\
\text { owned out-of-state plants }\end{array}$ & AEF, including imports ${ }^{\text {a }}$ \\
\hline PG\&E & 0.063 & 0.064 \\
SMUD & 0.057 & 0.058 \\
PG\&E+SMUD & 0.062 & 0.063 \\
SCE & 0.102 & 0.131 \\
SDGE & 0.102 & 0.146 \\
CAISO & 0.079 & 0.101 \\
\hline LADWP & 0.209 & 0.207 \\
\hline All CA & 0.099 & 0.105 \\
\hline
\end{tabular}

a All PG\&E imports were assumed to come from the Northwest, with an average emissions factor of 0.072 $\mathrm{kgC} / \mathrm{MWh}$. All SCE and SDGE imports were assumed to come from the Southwest, with an average emissions factor of $0.195 \mathrm{kgC} / \mathrm{MWh}$. (These figures calculated in section III.C.5.) The ISO imports were calculated from the sums of the imports for the three CAISO utilities. Imports to California as a whole were assumed to be $53 \%$ from the Northwest, and $47 \%$ from the Southwest, as reported by the CEC (2001b).

Table 23 shows the monthly AEFs for 1999, as calculated from the NEMS plant data, for California plants, including out-of-state plants owned by California utilities (but not including imports). These factors were calculated using the monthly capacity factors reported in the NEMS plant data. For each plant, in each month, the plant's electricity generation was calculated by multiplying the capacity (summer capacity was used for April through September, winter capacity for October through March) times the monthly capacity factor, times the hours in the month, times the percent of electricity delivered to the grid. The monthly carbon emissions for each plant were then calculated by multiplying that plant's generation by its emissions factor in $\mathrm{kg} \mathrm{C} / \mathrm{kWh}$. The AEF for each utility was calculated by adding up the carbon emissions of all of the plants, and dividing by the sum of the generation of all of the plants.

Table 23. Monthly Average Carbon Emissions Factors for 1999 in $\mathrm{kgC} / \mathrm{kWh}$, Excluding Imports

\begin{tabular}{l|c|c|c|c|c|c|c|c|c|c|c|c|c}
\hline & Jan & Feb & Mar & Apr & May & Jun & Jul & Aug & Sept & Oct & Nov & Dec & Variation $^{\text {a }}$ \\
\hline LADWP & 0.224 & 0.213 & 0.207 & 0.203 & 0.205 & 0.210 & 0.205 & 0.195 & 0.199 & 0.208 & 0.223 & 0.222 & $15 \%$ \\
PG\&E + & & & & & & & & & & & & \\
SMUD & 0.071 & 0.054 & 0.051 & 0.051 & 0.046 & 0.052 & 0.061 & 0.069 & 0.077 & 0.079 & 0.076 & 0.063 & $72 \%$ \\
SCE & 0.103 & 0.102 & 0.101 & 0.090 & 0.086 & 0.097 & 0.106 & 0.109 & 0.107 & 0.111 & 0.109 & 0.105 & $29 \%$ \\
SDG\&E & 0.094 & 0.087 & 0.091 & 0.093 & 0.091 & 0.098 & 0.115 & 0.120 & 0.117 & 0.105 & 0.095 & 0.095 & $38 \%$ \\
\hline All & 0.107 & 0.091 & 0.090 & 0.085 & 0.082 & 0.087 & 0.103 & 0.109 & 0.111 & 0.113 & 0.111 & 0.101 & $38 \%$ \\
\hline
\end{tabular}

The pattern of monthly AEFs appears to be strongly influenced by the pattern of hydro electricity production. Emissions factors statewide are lowest in the spring and early summer, when snowmelt occurs and hydro generation is at its peak. Emissions factors are highest in the fall, when hydro generation is at it lowest, and hot, dry weather often raises

${ }^{34}$ CAISO data for PG\&E includes the SMUD service territory. Therefore results for PG\&E and SMUD are reported both as combined, as well as separately where possible. 
demand. The largest variability in average monthly emissions factors is seen for the PG\&E/SMUD region, which also has the highest fraction of hydro electricity. The lowest monthly variation is seen for LADWP. This is likely due to the predominance of coal in that utility's fuel mix, since there is little seasonal variation in the operation of coal-fired power plants.

Table 24. Marginal Carbon Emissions Factors for 1999, in $\mathrm{kgC} / \mathrm{kWh}$

\begin{tabular}{|c|c|c|c|c|c|}
\hline Utility & $\begin{array}{c}\text { AEF for thermal } \\
\text { plants } 1^{\mathrm{a}}\end{array}$ & $\begin{array}{l}\text { AEF for thermal } \\
\text { plants } 2^{b}\end{array}$ & MEF $1^{c}$ & MEF $2^{d}$ & $\begin{array}{l}\text { Maximum } \\
\text { Variation }^{\mathrm{e}}\end{array}$ \\
\hline PG\&E+SMUD & 0.165 & 0.173 & 0.140 & 0.138 & $25 \%$ \\
\hline SCE & 0.233 & 0.243 & 0.215 & 0.216 & $13 \%$ \\
\hline SDGE & 0.167 & 0.215 & 0.181 & 0.181 & $29 \%$ \\
\hline CAISO & 0.192 & 0.217 & 0.193 & 0.193 & $13 \%$ \\
\hline LADWP & 0.239 & 0.241 & 0.199 & 0.200 & $21 \%$ \\
\hline
\end{tabular}

a in-state plus utility-owned out-of-state, excluding cogen, excluding imports

b in-state plus utility-owned out-of-state, excluding cogen, including imports

c ordered by fuel priority, then capacity factor, then cost, capacity factor method 1

d ordered by fuel priority, then capacity factor, then cost, capacity factor method 2

e percent difference between highest and lowest values

Table 24 shows the MEF calculated for each of the CAISO utilities separately, the CAISO as a whole, and for LADWP. It also shows the average EF for the thermal plants, excluding cogeneration, in each region. The first column of AEFs does not include thermal imports; the second column of AEFs does. Since it is expected that the plants on the margin will be thermal plants that are not cogeneration facilities, the average emissions factors of such plants can be used as a first order approximation of the marginal emissions factors. Because the impact of electricity conservation on imports is hard to predict, it is difficult to know if imports will be on the margin or not, therefore thermal AEFs with and without thermal imports were calculated. Thermal imports are likely to be reduced before non-thermal, because thermal generation is more expensive.

Two slightly different methods were used to calculate the marginal emissions. As plants are placed under the LDC curve, sometimes the reported capacity factor for that plant exceeded the capacity factor that would be expected for a plant at that point in the curve. In Method 1, the reported generation of electricity of the plant was kept constant, effectively allowing the capacity of the plant to increase above the reported capacity in order to fit that plant's electricity generation under the curve. In Method 2, the plant's reported capacity was kept constant, and the plant's generation was reduced to fit under the curve. In this second method, since the plant's generation is adjusted downward from the reported values, the upper portion of the LDC is not being completely filled - for this method, we report the MEF only for the portion of the LDC that is filled in, effectively assuming that the MEF in the upper portion of the curve will be the same as in the lower portion.

These two methods give somewhat different weights to each of the load-following plants' emissions in calculating the MEF. As can be seen in Table 24, the value obtained for the MEF for the two methods is nearly identical for all power control areas. 
The MEF calculated by the LDC method for PG\&E+SMUD is significantly lower than the AEF for the thermal plants in this power control area (including or excluding thermal imports). The reason for this is that the baseload portion of the LDC curve was completely filled by nuclear, non-thermal imports, renewables, cogeneration, plus some, but not all of the hydro generation. The remaining hydro generation therefore was placed into the load-following portion of the curve, along with thermal plants that are not cogenerators, plus thermal imports. Because some of the hydro appeared on the margin in the LDC calculation, the MEF is lower due to the inclusion of this carbon free resource. In reality, if electricity conservation caused the utility to have excess hydro generation that it could not use, it is likely that the utility would arrange a trade of this excess energy in return for energy back at a time that it could be used. The energy it would receive in trade would like be largely from thermal sources. Therefore, the MEF calculated here may underestimate the carbon content of conserved electricity. This problem may occur when the LDC method is used for utilities whose generation consists largely of carbon free resources that are either low cost, or "must-take", as is found in the PG\&E/SMUD power control area.

The MEF for SCE is somewhat lower than the AEF for thermal resources for this utility. In the case of SCE, the baseload is filled up by nuclear, non-thermal imports, renewables, cogeneration, hydro, plus some but not all of the thermal imports. This puts the remainder of the thermal imports, plus thermal non-cogen facilities on the margin. The reason the MEF is somewhat lower than the AEF for such facilities, is that all of the coal-fired facilities end up in the lowest part of the load-following portion of the LDC, and therefore are given less weight per $\mathrm{kWh}$ electricity generated than the natural gas-fired facilities that fill the upper portion of the LDC.

For SDGE, the thermal AEF that includes thermal imports is much higher than the thermal AEF that excludes them. This is because a very large fraction of SDG\&E's load is met by imports (nearly half), and the thermal imports are nearly all coal-fired. The MEFs calculated for SDGE are lower than the AEF that includes thermal imports. As with SCE, the baseload portion of SDGE's LDC was filled with all of the carbon free generators, plus cogenerators, plus some, but not all, of the thermal imports. And as with SCE, the MEF is lower than the thermal AEF (including imports) because coal-fired generation is being assigned to the lowest parts of the load-following portion of the LDC, and are therefore given less weight than gas-fired facilities in the upper portion of the LDC.

The pattern for the CAISO as a whole is similar to that described for SCE and SDGE, where thermal imports and other coal-fired facilities are in the lower part of the loadfollowing portion of the LDC, and natural-gas fired facilities are in the upper portions. A similar pattern is seen for LADWP as well, except that in the case of LADWP, the baseload part of the LDC accommodates all of the thermal imports plus a few of the larger coal-fired facilities (Intermountain, plus some of Navajo's generation), thus placing the rest of the coal-fired generators in the lower part of the load-following part of the LDC curve, with natural gas resources again in the upper portion. 


\section{E. PROSPECTS FOR LDC METHOD}

The LDC method is a relatively simple method that may be useful in separating baseload power generation from load-following generation. This makes it possible to make a firstcut identification of the plants whose generation is most likely to be curtailed when load is reduced due to electricity savings from conservation programs. By identifying the plants most likely to be on the margin, the marginal carbon emissions factor that applies to electricity savings from conservation programs can be estimated.

The method is likely to work best for utilities whose generation comes largely from thermal plants, and may not work as well for utilities whose generation includes a large fraction of inexpensive carbon free resources and/or many "must-take" facilities.

The most important area needing improvement is estimation and modeling of imports. Currently, they are included in the model as two dummy plants per power control area, representing imports from non-thermal and thermal sources. The non-thermal imports end up in the baseload portion of the LDC and therefore do not directly affect the calculated MEFs, although they do affect the contributions of other resources to the MEFs. However, thermal imports do end up in the load-following part of the LDC, and therefore do affect the calculated MEF. If more detailed information on imports were available, including information about which plants supply imported power, and what fraction of these imports are actually used to meet the load-following portion of the LDC, this would make it possible to more accurately determine the MEF. Additionally, the unreasonably high heat rates of some plants in the NEMS file need to be investigated. 


\section{CONCLUSION}

\section{A. COMPARISON OF RESULTS}

The three approaches yield reasonably consistent annual AEFs for the four utilities (see Table 25), with the exception that SCE's AEF from the LDC method is somewhat higher than the other two methods. The level of $\mathrm{CO}_{2}$ associated with electricity usage varies considerably among the utilities, although it comes as no surprise that these values are lower for PG\&E than for the southern California utilities. PG\&E has a large share of carbon-free generation, such as hydro, nuclear, and predominantly hydro imports from the Pacific Northwest.

Table 25. Summary of Annual AEFs for Three Emissions Factor Estimation Methods (kgC/kWh)

\begin{tabular}{l|c|c|c}
\hline & $\begin{array}{c}\text { 1990 AEFs } \\
\text { Using Elfin }\end{array}$ & $\begin{array}{c}\text { 1999 AEFs } \\
\text { Using LDC }\end{array}$ & $\begin{array}{c}\text { 1999 AEFs } \\
\text { Using PDS }\end{array}$ \\
\hline LADWP & 0.195 & 0.207 & 0.192 \\
SCE & 0.132 & 0.163 & 0.132 \\
SDG\&E & 0.132 & 0.131 & 0.140 \\
PG\&E & 0.068 & 0.064 \\
CAISO & 0.070 & 0.101 & \\
\hline California $^{\mathrm{b}}$ & 0.110 & 0.105 & 0.108 \\
\hline
\end{tabular}

${ }^{a}$ LDC and PDS results for PG\&E include Sacramento Municipal Utility District (SMUD).

${ }^{\mathrm{b}}$ Includes irrigation districts and municipal utilities.

Table 26 shows that the LDC and Elfin methodologies produced divergent MEFs for SCE and SDG\&E, and similar results for LADWP and PG\&E. With the exception of LADWP, MEFs are significantly higher than the corresponding AEFs. The difference in Elfin's 1990 and the LDC-derived 1999 MEFs for SCE is especially striking. The high 1999 MEF using the LDC method occurs because a large share of the gas-fired generation for this utility is from cogeneration, which is assumed not to respond to changes in the load. Thus, the load-following resources consist largely of imports from the Southwest. Since the MEFs of the PCAs other than LADWP range from $27 \%$ to over $120 \%$ greater than the corresponding AEFs, using AEFs to estimate $\mathrm{CO}_{2}$ savings from reducing electricity usage would significantly underestimate actual savings.

Table 26. Comparison of Annual MEFs from Two Electricity Emissions Factor Calculation Methods ${ }^{\mathrm{a}}(\mathrm{kgC} / \mathrm{kWh})$

\begin{tabular}{l|c|c}
\hline & $\begin{array}{c}\text { 1990 MEFs } \\
\text { Using Elfin }\end{array}$ & $\begin{array}{c}\text { 1999 MEFs } \\
\text { Using LDC }\end{array}$ \\
\hline LADWP & 0.191 & 0.199 \\
SCE & 0.165 & 0.221 \\
SDG\&E & 0.201 & 0.167 \\
PG\&E & 0.153 & 0.155 \\
\hline CAISO & 0.193 \\
\hline a & MEFs were not calculated using the PDS method \\
b & LDC results for PG\&E include Sacramento Municipal Utility District (SMUD).
\end{tabular}


The large share of seasonally varying hydro generation in California combined with typically hot late summer weather implies that AEFs may be higher when increased output from thermal generating sources must compensate for diminished hydro output. Conversely, as more thermal generation is used, the share of natural gas is likely to increase relative to coal, pushing down the AEF of thermal generation. Table 27 shows the AEFs calculated for May and October, months that usually have relatively high and low hydro generation, respectively. PG\&E, the most hydro-dependent utility, has by far the largest variation between the two months. This occurs both because more gas-fired generation is used by this utility, and more electricity is imported from the Northwest. The decrease in hydro generation also causes the AEF of the imported power to increase, as more coal-fired electricity is used to compensate for the reduction in hydropower. PG\&E, being the largest utility, is a large enough share of the statewide total load that the seasonal change in its resource mix significantly affects the statewide AEF. The variation in the other utilities is much less pronounced, being less influenced by differences in hydro output. This suggests that accounting for seasonal changes in resource mix, particularly for entities located in the PG\&E service area, is important to accurately estimate emissions throughout the year.

Table 27. 1999 Seasonal Changes in Average Emissions Factors (kgC/kWh)

\begin{tabular}{|c|c|c|c|c|c|c|c|}
\hline \multirow[b]{2}{*}{ Utility } & \multicolumn{3}{|c|}{ May } & \multicolumn{3}{|c|}{ October } & \multirow{2}{*}{\begin{tabular}{|} 
Percent \\
Difference \\
Oct/May \\
PDS Tota
\end{tabular}} \\
\hline & $\begin{array}{c}\text { CA } \\
\text { Generation } \\
\text { LDC }^{\mathrm{a}}\end{array}$ & \begin{tabular}{|c|} 
CA \\
$\begin{array}{c}\text { Generation } \\
\text { PDS }^{\mathbf{a}}\end{array}$ \\
\end{tabular} & $\begin{array}{c}\text { Total w/ } \\
\text { Imports } \\
\text { PDS }\end{array}$ & $\begin{array}{c}\text { CA } \\
\text { Generation } \\
\text { LDC }^{\mathbf{a}}\end{array}$ & \begin{tabular}{|c|} 
CA \\
Generation \\
PDS $^{\mathbf{a}}$
\end{tabular} & \begin{tabular}{|c} 
Total w/ \\
Imports \\
PDS
\end{tabular} & \\
\hline PG\&E & 0.051 & 0.043 & 0.046 & 0.080 & 0.079 & 0.083 & $79 \%$ \\
\hline $\mathrm{SCE}$ & 0.072 & 0.083 & 0.122 & 0.106 & 0.105 & 0.132 & $8 \%$ \\
\hline SDG\&E & 0.085 & 0.096 & 0.150 & 0.106 & 0.089 & 0.134 & $-11 \%$ \\
\hline LADWP & 0.205 & 0.194 & 0.192 & 0.208 & 0.184 & 0.184 & $-5 \%$ \\
\hline $\mathrm{CA}^{\mathrm{a}}$ & 0.082 & $0.074^{\mathrm{b}}$ & $0.098^{\mathrm{b}}$ & 0.113 & $0.103^{b}$ & $0.117^{\mathrm{b}}$ & $19 \%$ \\
\hline
\end{tabular}

${ }^{a}$ Includes the shares of out-of-state plants owned by CA utilities.

${ }^{\mathrm{b}}$ Includes only the PCAs listed in the table.

Programs that track various entities' total annual $\mathrm{CO}_{2}$ emissions from electricity consumption, as well as their estimated $\mathrm{CO}_{2}$ emissions reductions from mitigation efforts, must carefully choose electricity emissions factors in order to avoid potentially large errors. Using three different methods to estimate annual AEFs, MEFs, and seasonal AEFs by utility, Berkeley Lab found that using a simple annual statewide AEF could significantly under- or over-estimate an entity's indirect emissions due to the large variation in generating resources among the utility service areas. Also, differentiating between marginal and average emissions is essential to accurately estimate the $\mathrm{CO}_{2}$ savings from reducing electricity use. Seasonal differences in AEFs due to fluctuations in hydro generation should be accounted for at the statewide level, and particularly for the PG\&E area. 


\section{B. LESSONS LEARNED FROM DEVELOPING EACH METHOD}

\section{Public Data Sources}

Using public data sources to estimate $\mathrm{CO}_{2}$ emissions for this report revealed some important considerations, should this process be implemented in the future. Overall, the process consists of two parts. The first is determining how much electricity is produced at each generating station and how much carbon dioxide is emitted. The second part consists of assigning the electricity and the associated emissions to the sales pool of any particular utility area.

The first part is relatively straightforward using public data sources although there are some complications. The process is more challenging for California than it would be for other states due to the large share of independent power production, particularly for 1999. Following the terms of the restructuring agreement between the state and investor-owned utilities, these utilities had to sell most of their thermal generating assets. Therefore, most of the in-state carbon dioxide emissions are generated by nonutility owned power plants, making accurate estimation of nonutility emissions critical.

However, 1999 was a big transition year with many power plants changing hands, and this led to some inconsistencies in the data. First, there was some confusion on the Annual Nonutility Electric Generator Report (Form EIA 860B) over whether sales to resellers should count as sales to utilities or sales to end-users. Some large stations that sell virtually all of their power to associated resellers reported very little electricity being delivered to the grid. Until this mistake was corrected, most of these plants' emissions were not assigned to the grid power pool. Given the low average emissions factor in the state, these large plants can significantly affect the results. Second, the imputed operating efficiency of some plants changed dramatically once they had been purchased by independent power producers. Finally, monthly fuel consumption or electricity production totals sometimes did not add up to the reported yearly consumption or production. In cases where the discrepancies were large, the reporting managers of the energy service providers were contacted for clarification. After 1999, as those responsible for reporting data to the EIA become more familiar with the reporting requirements, this should be less of a problem.

Even without these inconsistencies, the presence of such a large number of independent power producers in California creates complications. Many of these producers use some of the electricity for their own industrial purposes, or the electricity is generated from combined heat and power. However, total fuel consumption is reported, so some method is required for allocating the portion of fuel consumed to produce the electricity actually delivered to the grid. For units that produce only electricity this allocation was relatively straightforward. The ratio of electricity delivered to utilities to the amount of electricity generated was used. The process is more complicated for units generating combined heat and power, and various methods for allocating the fuel shares between heat and electricity have been proposed in the energy efficiency literature (Phylipsen, Blok, and Worrell, 1998). 
However, it is the second part of the process, accounting for flows of imports and interPCA sales that is the most challenging part of the exercise. With the large share of imported power this would have been a complicated task before restructuring, but the transfer of much of California's generating capacity to independent power producers has also meant that sales and purchase data have become largely confidential. Without access to this data, simplifying assumptions need to be made.

\section{Elfin}

BRPU data provide a wealth of information on power plant operations in the 1990s. The Elfin modeling results using these data provide a window on conditions in that era that would not be accessible in any other way. However, each of the utility files was constructed independently by a group at each utility. Thus, there is little standardization among these files. Running Elfin based on this data has provided much historic insight as well as a crosscheck on the other estimates, but unraveling the assumptions in the input files and finding any bugs would be a major undertaking. It may also require considerable effort to adapt the model to simulate the deregulated market. These barriers impede Elfin's usefulness on an ongoing basis, although it may be useful for estimating historic emissions factors.

\section{Load Duration Curve}

One of the lessons learned from the LDC analysis is that the MEF that is calculated will be very dependent on the "probable dispatch order", or order in which plants are used to fill up the LDC curve. This is especially true for utilities like PG\&E, which has a lot of inexpensive carbon-free resources such as nuclear and hydro and a lot of "must-take" generation from sources like renewables and cogeneration.

The calculated MEF is also very sensitive to assumptions that are made about imports. We placed thermal imports high enough in the dispatch order that some of this energy was appearing in the load-following portion of the LDC. Not a lot of information was available for evaluating how imports are actually used in each of the utility areas studied. More detailed information about electricity imports would allow us to refine the calculated MEFs to better reflect how the systems are operated.

Encouragingly, the MEF was not very sensitive to two different calculation methods we used. In one of these methods, if a particular plant's calculated capacity factor (based on its position in the LDC curve) was less than the actual capacity factor (as reported in the NEMS plant file), the plant's capacity was held constant and its generation was reduced to fit the plant's generation under the LDC curve. In the other method, the plant's generation was held constant, and the calculated capacity was allowed to increase above the plant's reported capacity, again to fit the generation under the LDC curve. The MEFs calculated by these two methods were nearly identical for all of the utility systems examined. 
The NEMS input files are a useful source of electric plant data. The data is in a relatively easily understood format and is updated annually by EIA. These files contain most of the parameters needed for the LDC analysis, and the other parameters that are needed (e.g. carbon content of fuels) can be easily found. 


\section{ACKNOWLEDGMENTS AND FUNDING STATEMENT}

This work was supported by the California Energy Commission (CEC) and the California Institute for Energy Efficiency (CIEE) using support from the CEC through the U.S. Department of Energy under Contract No. DE-AC03-76SF0098. This work does not necessarily represent the views of the CEC, its employees or the State of California. Publication of these research results does not imply CIEE endorsement of or agreement with these findings, nor that of any of its sponsors. The authors express their thanks for the beneficial comments of reviewers on earlier drafts. The list of reviewers includes Guido Franco, Joe Loyer, Ross Miller, Adam Pan, and Jeff Wilson, all of the CEC; Dan Kirshner of Environmental Defense; and Neil Strachan of the Pew Center on Global Climate Change. We would also like to thank Dan Kirshner for his assistance with the Elfin model. 


\section{GLOSSARY}

97 Inventory 1997 Global Climate Change: Greenhouse Gas Emissions Reduction Strategies for California. Appendix A. Historical and Forecasted Greenhouse Gas Emissions Inventories for California reports inventory data for 1990-1994.

AEF average emissions factor

AEO Annual Energy Outlook

AER Annual Energy Review

ALAPCO Association of Local Air Pollution Control Officials

BRPU Biennial Resource Planning Update

CAISO California Independent System Operator

CalPX California Power Exchange, semi-official wholesale electricity exchange that operated from April 1998 through January 2001

CCP Cities for Climate Protection

CEC California Energy Commission

CHP combined heat and power, or cogeneration

$\mathrm{CH} 4 \quad$ natural gas, methane, and $\mathrm{CH} 4$ are used interchangeably in this report

DoE U.S. Department of Energy

CDWR California Department of Water Resources

EBRD European Bank for Reconstruction and Development

EF emissions factor

E-GRID Emissions and Generations Resource Integrated Database

EIA Energy Information Administration

EIIP Emission Inventory Improvement Program

Elfin Electrical Financial Model of Environmental Defense

EPA U.S. Environmental Protection Agency

ER96 CEC 1996 Electricity Report

ERT Environmental Resources Trust

ESPAR Electricity Systems Planning Assumption Report

FERC Federal Energy Regulatory Commission

FOR forced outage rate

GHGPI Greenhouse Gas Protocol Initiative

IEA International Energy Agency

IPCC Intergovernmental Panel on Climate Change

ICEM Iterative Cost Effectiveness Model

ICLEI International Council for Local Environmental Initiatives

ITRE Iterative Test of Resource Effectiveness

IID Imperial Irrigation District

LADWP City of Los Angeles Department of Water and Power

LDC load duration curve

MEF marginal emissions factor

MOR maintenance outage rate

munis municipal utilities, e.g. Cities of Burbank and Redding

NCPA Northern California Power Authority, group of munis such as the cities of Alameda and Roseville

NERC North American Electric Reliability Council 


$\begin{array}{ll}\text { OMET } & \text { Open Market Emissions Trading Program } \\ \text { PCA } & \begin{array}{l}\text { power control area, the area under the direction of one central control } \\ \text { room, usually a UDC service territory with some smaller entities included }\end{array} \\ \text { PG\&E } & \text { Pacific Gas and Electric Company } \\ \text { Registry } & \text { California Climate Action Registry } \\ \text { SCE } & \text { Southern California Edison Company, division of Edison International } \\ \text { SDG\&E } & \text { San Diego Gas and Electric Company, subsidiary of Sempra Corp. } \\ \text { SEDR } & \text { State Energy Data Report } \\ \text { SMUD } & \text { Sacramento Municipal Utility District } \\ \text { STAPPA } & \text { State and Territorial Air Pollution Program Administrators } \\ \text { T\&D } & \text { transmission and distribution } \\ \text { UDC } & \text { actually a California investor owned utility distribution company, i.e. } \\ & \text { PG\&E, SCE, or SDG\&E, however used loosely in this study for electricity } \\ \text { UN } & \text { utilities including municipals } \\ \text { UNEP } & \text { United Nations } \\ \text { VOC } & \text { United Nations Environment Programme } \\ \text { VRGGP } & \text { Volatile organic compound } \\ \text { WRI } & \text { World Resources Institute } \\ \text { WBCSD } & \text { World Business Council for Sustainable Development } \\ \text { WSCC } & \text { Western Systems Coordinating Council (recently renamed the Western } \\ & \text { Electricity Coordinating Council) }\end{array}$




\section{BIBLIOGRAPHY}

Arthur D. Little, Inc., 2002. Guidance to the California Climate Action Registry: General Reporting Protocol. Draft Consultant Report. Sacramento: California Energy Commission (P500-02-005D).

Australian Greenhouse Office (AGO), 2000. "About the Challenge." http://www.greenhouse.gov.au/challenge/html/about/html

Australian Greenhouse Office, 2001. Greenhouse Challenge Factors and Methods. http://www.greenhouse.gov.au/challenge/html/member-tools/factorsmethod.html

California Climate Action Registry, 2002. http://www.climaterigstry.org/

California Energy Commission (CEC), 1990. 1990 Electricity Committee Report: Appendices. (P106-90-002A). Sacramento, CA: CEC.

California Energy Commission, 1993. 1992 Electricity Report: Appendices. (P104-92001A). Sacramento, CA: CEC.

California Energy Commission, 1995. 1994 Electricity Report: Appendices. (P300-95002A). Sacramento, CA: CEC.

California Energy Commission, 1998. 1997 Global Climate Change: Greenhouse Gas Emissions Reduction Strategies for California. Appendix A: Historical and Forecasted Greenhouse Gas Emissions Inventories for California. Sacramento, CA: CEC.

California Energy Commission, 2000. "California energy demand, 2000-2010" (P200-00002). Sacramento, CA: CEC.

California Energy Commission, 2001a. 2000 California Net System Power Calculation. http://38.144.192.166/sb1305/2001-04-04_SYSTEM_POWER.PDF

California Energy Commission, 2001b. California Electricity Generation, 1983 - 2000. http://www.energy.ca.gov/electricity/ELECTRICITY_GEN_1983-2000.XLS

California Energy Commission, 2001c. Draft Staff Report: Inventory of California Greenhouse Gas Emissions and Sinks: 1990 - 1999. (forthcoming)

California Energy Commission, 2001d. Reconciliation of Retailer Claims, 2000. Sacramento, CA: CEC. P500-01-019

California Independent System Operator (CAISO), 2001. System Load Reports. http://oasis.caiso.com/

California State Senate. 1997. Senate Bill 1305, 1997-1998 Session. 
http://info.sen.ca.gov/pub/97-98/bill/sen/sb_1301-1350/

sb_1305_bill_19971009_chaptered.html

Chen, S, 2001. Personal communication with Sandra Chen of New Jersey Department of Environmental Protection.

Colburn, K, 2001. Personal communication with Ken Colburn of New Hampshire Department of Environmental Services.

DeLucchi, MA, 1997. A Revised Model of Emissions of Greenhouse Gases from the Use of Transportation Fuel and Electricity: Table 6c. Davis, CA: Institute of Transportation Studies, UC Davis. Working Paper UCD-ITS-RR-97-22.

Edison Electric Institute (EEI), 2001. "Per Capita Electricity Consumption by State: 1999."

http://www.eei.org/future/wise_use/US_state_consumption.pdf

Emission Inventory Improvement Program (EIIP), 1999. Estimating Greenhouse Gas Emissions. http://www.epa.gov/ttn/chief/eiip/techreport/volume08/index.html

Environmental Resources Trust, Inc. (ERT), 2001. GHG Registry Program. http://www.ert.net/ghg/index.html

Federal Energy Regulatory Commission (FERC), 2001. FERC Form 714: WSCC 1999. http://www.ferc.gov/ELECTRIC/F714/DATA/1999wscc1.exe

Greenhouse Gas Protocol Initiative (GHGPI), 2000. Corporate Greenhouse Gas Inventories: Proposed Reporting Standard Guidance and Estimation Tools.

http://www.ghgprotocol.org/dsg.html

Greenhouse Gas Protocol Initiative (GHGPI), 2001. The Greenhouse Gas Protocol: A Corporate Accounting and Reporting Standard.

$\mathrm{http}: / /$ www.ghgprotocol.org/standard/ghg.pdf

Intergovernmental Panel on Climate Change (IPCC), 1996. 1996 IPCC Guidelines for National Greenhouse Gas Inventories (Revised). IPCC.

http://www.ipcc-nggip.iges.or.jp/public/gl/invs1.htm

Intermountain Power Agency (IPA). 2002. "About IPA."

http://www.ipautah.com/pdf/aboutipa.pdf

Meyers, S, C Marnay, K Schumacher, and J Sathaye, 2000. Estimating Carbon Emissions Avoided by Electricity Generation and Efficiency Projects: A Standardized Method. Berkeley, CA: Lawrence Berkeley National Laboratory. LBNL-46063. 
Meyers, S, C Marnay, and D Fisher, 2001. Development of Emissions Factors for Quantification of Environmental Benefits. Report to the State of Wisconsin, Department of Administration, Division of Energy, 9 May 2001.

Mosher, E, 2001. Personal communication with Eric Mosher - Wisconsin Department of Natural Resources.

New Hampshire General Court (NHGC), 1999. Senate Bill (SB) 159: Final Version. http://gencourt.state.nh.us/legislation/1999/SB0159.html

Pan, A, 2001. Personal communication with Adam Pan, CEC.

Phylipsen GJM, K Blok, and E Worrell, 1998. Handbook on International Comparisons of Energy Efficiency in the Manufacturing Industry. Utrecht, Netherlands: Utrecht University.

Rawson, B, 2001. Personal communication with Brian Rawson, Canadian VCR.

Thomas, C, T Tennant, and J Rolls, 2000. The GHG Indicator: UNEP Guidelines for Calculating Greenhouse Gas Emissions for Businesses and Non-Commercial Organizations. Geneva: United Nations Environment Programme.

http://www.unepie.org/energy/activities/Efficiency/GHGindicator/GHGindicator.htm

Tharp E, 2002. Personal communication with Eric Tharp, LADWP.

Torrie R, 2001. Personal communication with Ralph Torrie, Torrie Smith Associates.

Torrie Smith Associates, 2001a. Cities for Climate Protection - Greenhouse Gas Emissions Software. http://www.torriesmith.com/

Torrie Smith Associates, 2001b. e-Mission: Greenhouse Gas Strategy Software. http://www.torriesmith.com/

United Nations (UN), 2001. Framework Convention on Climate Change. National Communications. http://www.unfccc.de/resource/natcom/index.html

U.S. Department of Energy (DOE), 1996. "Climate Challenge Program Report.” http://www.eren.doe.gov/climatechallenge/progressreport/secx1.htm

U.S. Department of Energy and U.S. Environmental Protection Agency (US DOE/US EPA), 2000. "Carbon Dioxide Emissions from the Generation of Electric Power in the United States.” http://www.eia.doe.gov/cneaf/electricity/page/co2_report/co2report.html

U.S. Department of Energy, Energy Information Administration (US DOE/EIA), 1997. 1996 Emissions of Greenhouse Gases in the United States. Washington, DC: U.S. DOE, EIA. 
U.S. Department of Energy, Energy Information Administration, 2000a. Emissions of Greenhouse Gases in the United States 1999. Washington, DC: U.S. DOE, EIA. http://tonto.eia.doe.gov/FTPROOT/environment/057399.pdf

U.S. Department of Energy, Energy Information Administration, 2000b. Natural Gas Annual, 1999. Washington, DC: U.S. DOE, EIA.

http://www.eia.doe.gov/pub/oil_gas/natural_gas/data_publications/historical_natural_gas _annual/historical/1999/pdf/hnga99.pdf

U.S. Department of Energy, Energy Information Administration, 2000c. Quarterly Coal Report: October-December 1999. Washington, DC: U.S. DOE, EIA. DOE/EIA0121/(99/4Q)

http://tonto.eia.doe.gov/FTPROOT/coal/qcr/0121994q.pdf

U.S. Department of Energy, Energy Information Administration, 2001a. State Energy Data Report 1999. http://www.eia.doe.gov/emeu/sedr/contents.html

U.S. Department of Energy, Energy Information Administration, 2001b. Voluntary Reporting of Greenhouse Gases 1999. http:/www.eia.doe.gov/oiaf/1605/vrrpt/

U.S. Department of Energy, Energy Information Administration, 2001c. Annual Energy Review 2000. http://www.eia.doe.gov/emeu/aer/contents.html

U.S. Department of Energy, Energy Information Administration, 2001d. "Updated StateLevel Greenhouse Gas Emissions Factors for Electricity Generation." http://tonto.eia.doe.gov/FTPROOT/environment/e-supdoc.pdf

U.S. Department of Energy, Energy Information Administration, 2001e. "U.S. Natural Gas Sector Data.” http://www.eia.doe.gov/oil_gas/natural_gas/info_glance/sector.html

U.S. Department of Energy, Energy Information Administration, 2001f. Form EIA-906 Database: Monthly Nonutility Power Plant Database, 1999.

http://www.eia.doe.gov/cneaf/electricity/page/eia906u.html

U.S. Department of Energy, Energy Information Administration, 2001g. Annual Electric Utility Data: EIA-861 Data File, 1999.

http://www.eia.doe.gov/cneaf/electricity/page/eia861.html

U.S. Department of Energy, Energy Information Administration, 2001h. Annual Electric Generator - Nonutility: Form EIA-860B Database, 1999.

http://www.eia.doe.gov/cneaf/electricity/page/eia860b.html

U.S. Department of Energy, Energy Information Administration, 2001i. Form EIA-906 Database: Monthly Nonutility Power Plant Database, 1999.

http://www.eia.doe.gov/cneaf/electricity/page/eia906nonu.html 
U.S. Department of Energy, Energy Information Administration, 2001j. Input files to the Electricity Market Module of the National Energy Modeling System. For documentation see the Electricity Market Module: Model Documentation Report. DOE/EIAM068(2001) http://tonto.eia.doe.gov/FTPROOT/modeldoc/m0682001.pdf. Data files must be obtained by request from the EIA.

U.S. Environmental Protection Agency (US EPA), 1999. Estimating Greenhouse Gas Emissions. Vol. VIII: Chapter 1 "Methods for Estimating Carbon Dioxide Emissions from Combustion of Fossil Fuels."

http://www.epa.gov/ttnchie1/eiip/techreport/volume08/index.html

U.S. Environmental Protection Agency, 2001a. Inventory of U.S. Greenhouse Gas Emissions and Sinks: 1990-1999. Washington, DC: U.S. EPA.

http://www.epa.gov/globalwarming/publications/emissions/us2001/index.html

U.S. Environmental Protection Agency, 2001b. "Inventory Protocol."

http://www.epa.gov/climateleaders/protocol.html

U.S. Environmental Protection Agency, 2001c. E-GRID: The Emissions and Generation Resource Integrated Database. http:/www.epa.gov/airmarkets/egrid/index.html

U.S. Environmental Protection Agency, 2001d. State Inventory Guidance. http://yosemite.epa.gov/globalwarming/ghg.nsf/emissions/EIIPGuidance?Open

U.S. Environmental Protection Agency, 2001e. State GHG Inventories.

http://yosemite.epa.gov/globalwarming/ghg.nsf/emissions/StateAuthoredInventories

VCR-MRV, Inc., 1999. Registration Guide 1999. http://www.vcr-mvr.ca/vcr-180.cfm

Wisconsin Senate, 1999. Senate Bill 287 Section 285.78. Unofficial Text from Wis. Stats. Database Chapter 285: Air Pollution. http://www.legis.state.wi.us/statutes/99Stat0285.pdf 